

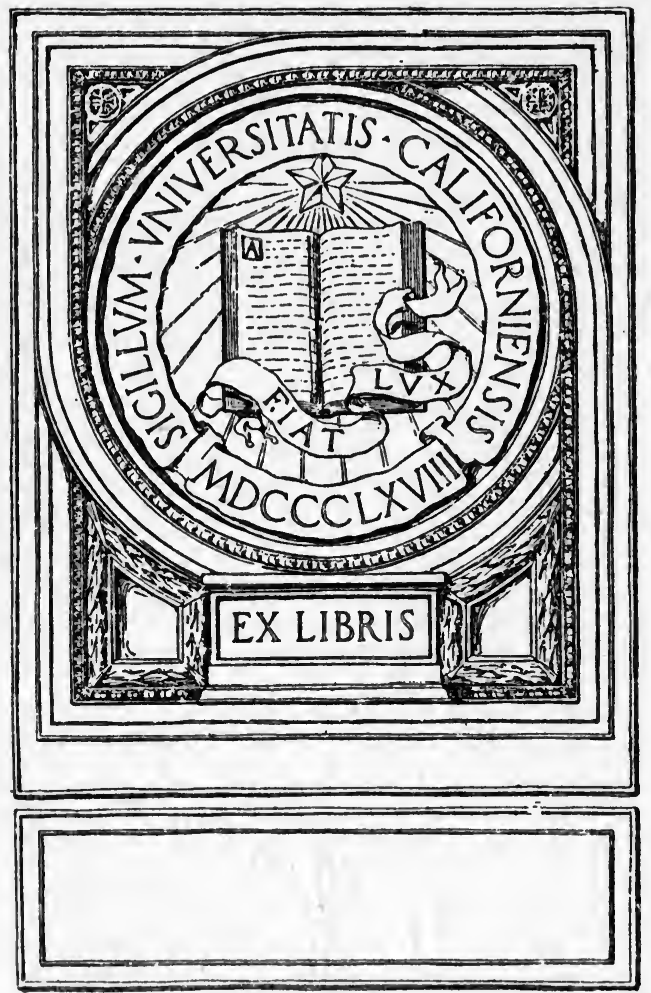


Digitized by the Internet Archive in 2008 with funding from Microsoft Corporation 
THE FALL OF TSINGTAU 



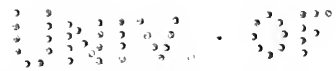

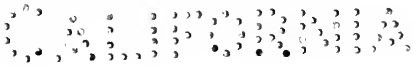



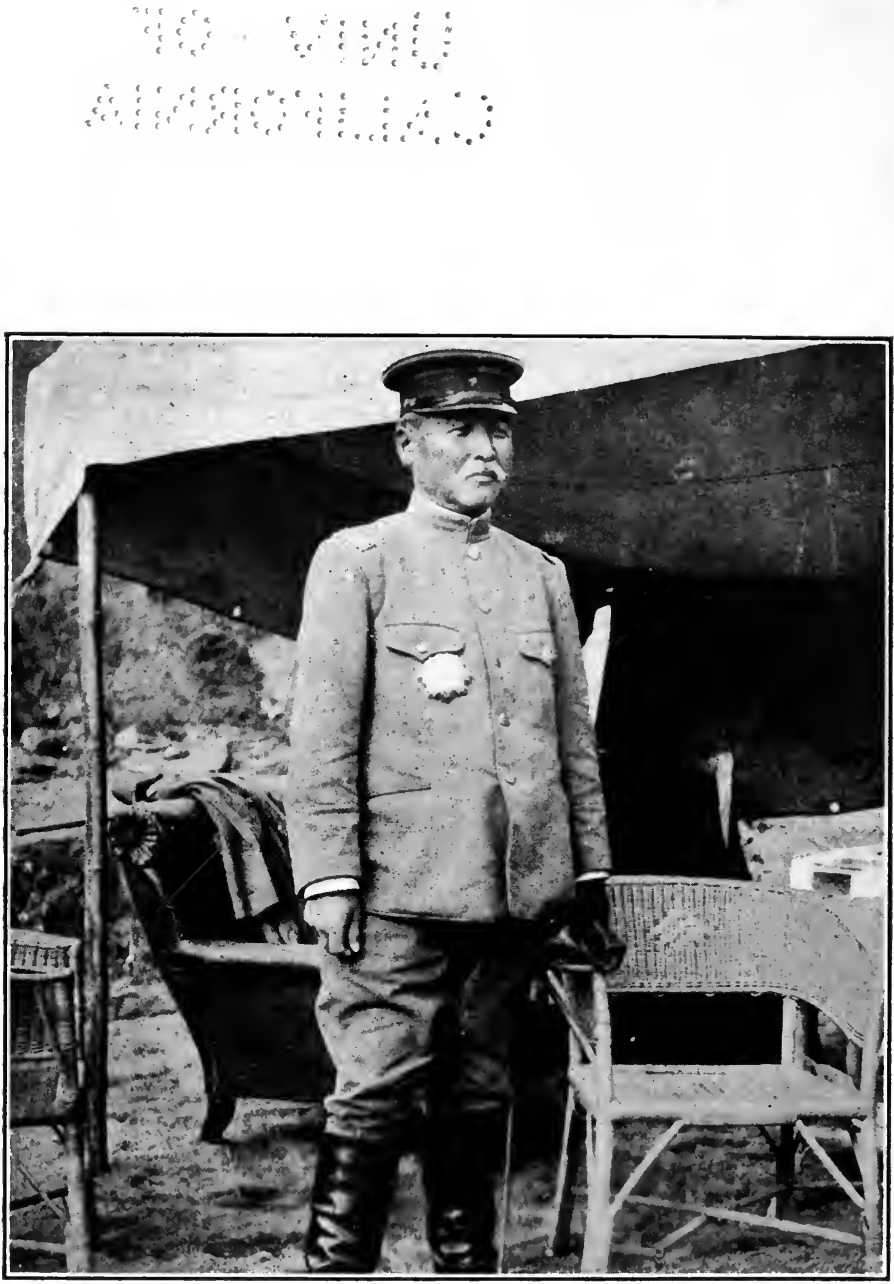

GENERAL KANIO

Commander-in-chief of the allied forces in the Kiaochow campaign. The first representative of the yellow race to hold command over a white force in battle 


\section{THE FALL OF TSINGTAU}

WITH A STUDY OF JAPAN'S AMBITIONS IN CHINA

\section{By JEFFERSON JONES}

WITH ILLUSTRATIONS

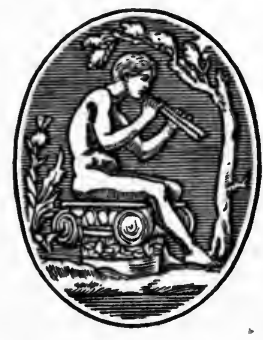

BOSTON AND NEW YORK

HOUGHTON MIFFLIN COMPANY

(Cbe Riberpide Preg Cambrioge 1915 
COPYRIGHT, 19I5, BY JEFFERSON JONES

ALL RIGHTS RESERVED

Published October 1915

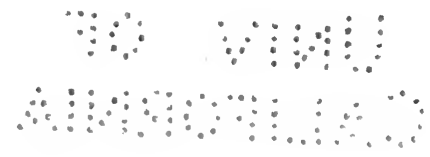


TO

MY FATHER 



\section{PREFACE}

ONE of the most remarkable changes to be wrought in Christendom by the greatest of wars will be found, not in Europe or in Europe's dependencies, but in the Far East. The destiny of as many Chinese as there are white human beings in all Europe may be determined by the event of August, 1914.

In the following pages I have attempted to record, as a disinterested observer, just what happened in the Orient from the time Europe took up arms and Japan, as to the policy she was to play, was left alone in Asia. That Japan's part in the seizure of the German protectorate of Kiaochow was essentially a blind move in the making over of the Celestial Kingdom into a dependency of Japan, cannot be doubted by any one who follows closely the moves of the Tokyo Government from the opening of the European war until China, after much harassing, acceded to the demands of Japan in May. 


\section{PREFACE}

While China may nominally be in possession of many of its sovereign rights, the fact is, the power which controls Tokyo, for all intents

- and purposes, now controls the Government at Peking. Events yet to take place in the Far East may be depended on to prove this assertion.

Be that as it may, China, we believe, will yet be a nation - independent, possessing sovereign rights, and governed by its own people. For the Chinaman remains a Chinaman. Deprive him of his country, isolate him from his people, and whether you find him in Caracas, Cape Town, or Halifax, he, and his generations that follow, will cling to the customs of his former country. The Chinese have not learned what patriotism is. They will in time. Then let a leader arise to join in one cause the four hundred and fifty millions of people of China; let patriotism once be grasped by them after repeated humiliations, such as have already been their lot in the last thirty years, and then one will recall the words of Napoleon, who said of China, "There lies a sleeping giant. Let him sleep; for when he moves he will move the world." 


\section{PREFACE}

Under the Tokyo domination, China is bound to learn by experience what it is to possess independent and sovereign rights; self-interest and the "squeeze" will become obsolescent words in the Chinese vocabulary, and gradually the nation that produced the philosopher Confucius will take on a national consciousness from which a truly awakened China will spring, and above all a China which will command from the world, not humiliating and jealous designs, but thorough-going respect.

From my experience as a resident in Tokyo, I feel there is much in the following pages that will strike the supersensitive hearts of the Japanese as an indication of my unfriendliness to the Nippon Kingdom. This is an impression which I do not wish for, as I think the Japanese a people of great ability and a nation the most patriotic and one of the most efficient in the world. My objection lies only against the diplomacy practiced by Japan during and since the siege of Tsingtau, believing that it in no degree reflects credit on the glory of the Rising Sun. I base this statement upon the very words and actions of Japan herself; inconsist- 


\section{PREFACE}

ent words and actions which require no special emphasis from an observer in the Far East.

As I write this there has arisen opposition in the Diet of Japan, which, like all oppositions where bureaucracy controls, does not carry much weight. It has denounced the Government's Chinese policy as one which has thrown a blight on the prestige of the nation. One of its radicals has publicly denounced Baron Kato, Foreign Minister, as a "traitor" to his Government. Cabinet Ministers' have been called upon to explain certain actions of the Government in Japan, all of which has further brought out the inconsistency of Japan's diplomacy.

For example, in the opposition's denunciation of Japan's foreign policy, Mr. Motoda, ex-Minister of State, referred to the Government's rushing troops and a battleship to China during the May breach in the negotiations on the twenty-one demands, as a forceful "threat" upon China. In reply to this, Baron Kato said that Japan was not increasing her troops in China as a threat, but the transaction was merely an exchange of guards. But as 


\section{PREFACE}

there was no exchange in troops, - that is, the troops in China did not return to Japan after the new troops arrived, - Mr. Tokohami, expresident of the Imperial Railroad Board, became more inquisitive and called upon Lieutenant-General Oka, the Minister of War, to explain before the Diet just why the Government had sent fresh troops into China. To this the Japanese Minister of War replied that it was because of disturbances, an answer wholly aside from Baron Kato's statement. But the opposition in the Diet pressed for the answer and questioned Minister Oka as to what disturbances in China the troops had been rushed to put down. At length Oka replied there had been no disturbances in China warranting the dispatch of fresh troops, but there had been a likelihood of friction. To every foreigner in Japan who knows that the Japanese exchange of guards takes place annually in December, this measure taken by Tokyo during the days in May, when Japan had warned China that "harsh" steps would be taken unless the latter acceded to the demands then under negotiation in Peking, there is but one 


\section{PREFACE}

answer, one reason, as to the wherefore of the hasty dispatch of troops into Asia by Japan.

Since that date Premier Okuma's Cabinet has resigned and Japan is torn internally with political strife. The Britisher in Shanghai, Peking, Manchester, and the other industrial centers of Great Britain, is disturbed at the actions of her ally in the Far East, and presses his Government in London for an understanding. The utmost calmness over the recent turn of events in the Far East is the only answer that is allowed to escape the House of Parliament in London. Meanwhile those far-sighted rulers of Japan - the Elder Statesmen seem to catch the future trend of events, for in July they were called together and considered the formation of an alliance with Russia, similar to the Anglo-Japanese alliance. In all probability definite action will be postponed until the treaty of peace in Europe or until the expiration of the British alliance.

With Russia, long a seeker for the partition of China, allied with Japan, events of international importance seem destined to follow. 


\section{PREFACE}

Will Russia's long-sought-after open-the-yearround Pacific port be a factor in the alliance? Will Taku, the port of Tientsin in northern China, come under Russian control with the consent of Tokyo, as rumor has it? In the mean time Japan's domination of China; the reconsideration of the demands at Peking which Japan explicitly labeled in May as only "postponed"; the "open door" in China and its latch; the treaty of peace in Europe, which will also terminate the Kiaochow affair, and the proposed Russian alliance - upon the outcome of these questions does the follower of events in the Far East look with eagerness. As peace day by day nears its realization in Europe, the clouds gather toward Asia, and with them a silence suggestive of the lull before the storm.

In closing, I wish to express my thanks and appreciation to General Kamio, commander of the Allied forces at Tsingtau, to Lieutenant Colonel Haraguchi, and to Mr. Zumota, civil attaché of the Japanese army, for their many courtesies extended to me while within the lines of their army; also to 


\section{PREFACE}

Mr. Post Wheeler, Mr. B. W. Fleisher, and

Mr. Carl Crow, my grateful acknowledgment for their assistance in getting me to the war front at Kiaochow.

J. J.

Monneapolis, August, 1915. 


\section{CONTENTS}

I. Japan's Dream of Domination a . 3

II. Preliminaries to the Declaration of War 15 III. The Violation of Neutrality . • • . 40

IV. The Advance of the Japanese Army • . 49

V. Closing in the Offensive • • • . . 55

VI. The Germans withdraw to Tsingtad . 61

VII. The Beginning of the Siege . • . . 70

VIII. The Fleet bombards the City • . . 78

IX. The Surrender • • . • . • . . 87

X. After the City's Fall . . . . . . 94

XI. Taking Possession • • • • • • 106

XII. Sanitation and Discipline . • • . . 111

XIII. Observations • • • • • • • • . 116

XIV. Japan and America: Peace or War? . . 122

XV. Bushido vs. Great Britain . . . . . . 141

XVI. What Ggrmany did in Kiaochow • • 153

XVII. Japan and her Game in China • • • 170

XVIII. The Passing of China as a Sovereign

NAtion • • • • • • • • • • . 182

XIX. The Restoration of Kiaochow . . • . 208

XX. The Enigma among Nations • • • . 211 



\section{ILLUSTRATIONS}

General Kamio, Commander-in-Chief of the Athed Troops in the Kiaochow Campatgi Frontispiece General Yamashita, Chief of the Japanese Staff 32

Japanese Infantrymen, showing the EquTpMent that makes UP the Fifty-Pound Pack-Sack . . 32

Japanese Aeroplane preparing for a Flight over the City of Tsingtau . . . . . . . . . 50

The Moltke Barracks at Tsingtad, showing the Work of Bombs from the Japanese Aeroplanes 50

On the March throdgh a Chinese Village in KLAOCHOW . . . • • . . . . . 58

Trophy Relics from the Franco-Prussian War, used in the Defense of Tsingtad . . . . 58

Headquarters of the General Staff of the Japanese Forces at Tschang-tsun . . . . 70

Tsingtau as it appeared from the Japanese Staff Office at Tschang-tsun on the Morning of Остовеr $31 \quad$.

Japanese Supply Colum on the Way to the Rear Line on the Day of the Opening of the Siege 76

Japanese Staff Officers viewing the Operations of the Siege from the Top of Prince Heinrich BERG . . . . . . . . . . . . 76

Quarters of the Japanese Staff Officers during the Closing Days of the Siege . . . . . 82 xvii 


\section{ILLUSTRATIONS}

Two German Machine-Guns on the Redoubt Walls of the Tsingtad Forts . . . . . . . . 82

German Barbed-Wire Entanglements along the Redoubt Walls • • • • • • • • . 90

General Horiuchi on the Crest of Moltke Fort, Which he ANd his Men Captured . . • . 90

The Foot of the Casemate Walls Thirty MrnUtES AFTER the SURRENder

The Moltke Barracks after the Surrender . . 98

Japanese Buglers announcing the Triomphant Entry of the Japanese Troops into Tsingtad . 108

Paying Respeet to the Souls of the Japanese Dead . . . . . . . . . . . . 108

A British Sentry at Tsingtad . . . . . . 142

Chinese Coolies at Work on the Portable Army Ratlroad • . • • . . • • . • . 142

Christ Church, one of the Few Buldotygs iv Tsingtad to go Unscathed throdgh the Siege 162

General Barnardiston and the British Expeditionary Force passing in Review before General Kamio on the Entry of the Aluied Troops into Tsingtad. Showing the Prince Heinrich Hotel used as a Hospital . . . . . . 162 


\section{THE FALL OF TSINGTAU}





\section{THE FALL OF TSINGTAU}

\section{CHAPTER I}

JAPAN'S DREAM OF DOMINATION

The fall of Tsingtau and the wiping-out of the German colonies in Asia and in the Pacific, at any other time than as a side happening in the greatest of wars, would have attracted the attention of the whole world. With the rapid unfolding of events in Europe during early August, 1914, the nations focused attention on the continent, where the largeness of events had the effect of making minor the developments in the Far East. The passing of Germany from Asia, however, is of great international importance, for from it there may be traced the future remapping of Asia and even the dissolution of China as a nation.

Japan's participation in the European war and the events that followed may be divided into two parts; first, the "game" she played in going to war; second, the actions of her army in the overthrow of Germany in Asia. 


\section{TEIS FALL OF TSINGTAU}

In discussing the first of these divisions, it is necessary to note the "sayings" of the Japanese statesmen in conjunction with the actions that followed. In this way only will it be possible to reach an intelligent conclusion. It is not what we say we will do, but what we do, that really counts, and in no relation does this rule apply more positively than in diplomatic dealings. It will not be difficult to discover that Japan's part in the European war was not for the "peace of the Far East," as declared by her diplomats at the outset, but a move in her ambition to dominate China.

The opening of hostilities between Japan and Germany in August, 1914, gave to Japan another opportunity to express in words just what were her motives in going to war, and it afforded opportunity also for the distribution in publications in America and Great Britain of frequent references to Japan's "love" for China.

"We have always stood and will continue to stand for the territorial integrity" and "neutrality" of China, writes Count Okuma, Premier of Japan, at the opening of the war. By 


\section{JAPAN'S DREAM OF DOMINATION}

those unaquainted with Far Eastern politics, and especially those of Japan, this statement by a Japanese statesman may have been read with confidence. However, those familiar with Japanese affairs do not accept such statements as conclusive.

Many times before has Japan vouched for the territorial integrity and neutrality of China. We have followed her actions only to find that the declarations of her statesmen were mere diplomatic nothings, their actions the exact opposite of their printed resolutions. For these reasons the official utterances of the Tokyo Government, on the opening of hostilities against Kiaochow, came and went without leaving sincere impression.

"What is Japan's game?" was the question passed among foreigners in the Japanese capital late in August, 1914. A step in the acquisition of China, was of course the answer, but many accepted Japan's statements, this time with more faith. With Great Britain as her ally, they said Japan would play with her cards on the table. Later events proved that Japan was playing her usual concealed game. 


\section{THE FALL OF TSINGTAU}

In all diplomatic tangles in the Far East for the last twenty years, China has paid the bill, whether she has been involved in the transaction or not. All the Powers have gone on record as standing for the territorial integrity of China, and the preservation of China's neutrality, but there has been but one Power, in its dealings with China, that has always backed guaranties by actions, not words - the United States.

During the above period, while Japanese statesmen were addressing the world to the effect, as Baron Kato recently put it, that "Japan maintains to protect the peace of the Far East" and to "guard China from foreign encroachments," her Government has taken from China, first, Formosa; then the Liaotung Peninsula; next, Korea; and now - shall we say Shantung?

While Japan's statesmen have been proclaiming that Japan is a friend to China, that she bears no ill-will against her, their hands have been slyly going into the pocket of China, and bit by bit has Celestial territory been taken. Is it to be wondered that during the 


\section{JAPAN'S DREAM OF DOMINATION}

recent war in the Far East the foreigner should look with distrust upon the actions of Japan?

Sunday, August 23, the day of Japan's declaration of war upon Germany, found the Japanese fleets in a semicircle in the Yellow Sea, making preparations for running the blockade to the Bay of Kiaochow. Still farther north, off the Korean archipelago, Japanese transports had already sailed bearing three divisions of the Imperial regiments. The Japanese Minister at Peking at once started negotiations for fixing the war zone about Kiaochow, Germany's protectorate in Shantung, Tsingtau being the capital.

China proposed that the said zone should not extend farther westward than 20 li to the east of Wei-hsien, but Japan objected to this, and argued that such a boundary would be difficult to observe, as they might be considered "to have violated China's neutrality" if a few of the Japanese troops wandered beyond this boundary. China, however, declined to modify her proposal, and eventually Japan acceded to her wishes, adding that, 


\section{THE FALL OF TSINGTAU}

while no troops would occupy the railroad beyond the war zone, it might be found necessary to send officers to Wei-hsien for the purchase of supplies. Upon this understanding did Japan send her troops into China to drive Germany from Shantung.

On September 2, news reached Peking that several Japanese transports had arrived at Lungkow, a port under Japanese influence in northern Shantung, and that troops were being disembarked. Just why Lungkow, a port situated one hundred and fifty miles from Tsingtau and in a mountainous district, practically devoid of roads suitable for military purposes, should have been the spot from which Japan first started war operations against Germany, remained a question that the Far East was unable to answer at the time, but events that followed after the disembarkation brought out the answer clearly.

With the German Kiaochow garrison miles away, Japan began the long, tedious journey across Shantung, where heavy rains and floods made difficult the advance of troops. Arriving at Tsimo the middle of September, the troops 


\section{JAPAN'S DREAM OF DOMINATION}

advanced westward, and about September 20, Peking was suddenly startled by the report that the Japanese troops had occupied Weishien, and were advancing still farther westward along the Shantung railroad and beyond the defined war zone.

By this unnecessary action Japan had violated the neutrality of China. And, though England had joined in the European war because Germany had violated the neutrality of Belgium, the British Government, for some reason unknown, did not think it necessary, when all the eyes of the world were upon $\mathrm{Eu}$ rope, to protest loudly, to her ally in China, against the very thing that had seemingly so shocked her in Belgium.

Western Shantung was now in disorder and confusion. With the Japanese troops quartered over this district there were many clashes between the native soldiery and the Japanese troops, and it required a steady hand in Peking to check a revolution or a war.

And by this same action did Japan prove to the world that it was not "the maintenance of the peace of the Far East" that had brought 


\section{THE FALL OF TSINGTAU}

her into the European struggle, but rather her political ambition.

So serious was the situation in Shantung, the Council of State at Peking was hurriedly called together to discuss Japan's breach of faith. A resolution was unanimously passed calling for interpretation of the Government's policy concerning China's neutrality. In moving the interpretation Liang Chi Chao, a member of the Council, said: -

"Since the outbreak of the European war, President Yuan Shi Kai has represented the nature of China's diplomatic relations and we sympathize with the Government's difficult situation, but the events and the rapid movements of the last twenty days leads to the belief that his reports are incomplete. Since the people are most indignant, the duty has devolved upon us to ask the Government for an explanation. When Japan declared war upon Germany, we were forced to delineate a war zone. However, Japan has violated our neutrality by occupying Wei-hsien and preparing to seize the railroad beyond the limits set forth. 


\section{JAPAN'S DREAM OF DOMINATION}

"I ask, are there any German soldiers west of Wei-hsien? The westward movement of the Japanese is nothing but a geographical movement? Judging from the actions of their army, Tsingtau is not their objective, but they are trying to occupy the whole of Shantung Province, which they will turn into another Manchuria. Britain cannot be excused for violating our neutrality, because its action is taken in concert with Japan. Britain has warred to uphold the neutrality of weak nations, thus gaining our respect, but in China it has followed a different policy, using the Allies' forces to violate the neutrality of Shantung. The Japanese outrages are facts and the Government should not look upon the people's sufferings with indifference."

"Japan, by attacking Tsingtau," said Chen Kuo Hsiang, another member of the Council, " is following out a continental policy cherished for the last twenty years. Its purpose is to seize Tsinan-fu and the northern sections of the Tien-tsin-Pukow railways. The situation confronting us is most grave. I fear that Shantung will become a second Manchuria. If 


\section{THE FALI OF TSINGTAU}

Japan takes Shantung, what will become of the nation?"

The Council of State even discussed war against Japan, when General Choa Wei Hsin jumped to his feet and shouted:-

"Should the people of China refuse to become slaves? There is hope that this country is becoming strong again. Should the people be abused? Then it is better for us to die than to live."

"Yes, the people must unite to prevent their own destruction," quickly responded General Wang Yi Tang. "Apparently Japan can seize anything it wants as a prize of war. This must be stopped. We are unprepared to face this emergency, but we must make immediate preparations to cope with the situation."

Looking with distrust upon Japan's actions, and regarding them as a serious breach of faith, China at once issued a protest to Japan. There followed the usual evasion by the Japanese diplomats. Japan intimated in her reply to the Foreign Office at Peking that she intended to go a step farther - to occupy the 


\section{JAPAN'S DREAM OF DOMINATION}

Shantung railroad from Kiaochow to Tsinan-fu. Again did China protest against the violation of her neutrality, adducing legal arguments this time to back up her claim. In reply to this a note was handed the Chinese Minister at Tokyo in which the Japanese Government "announced its intentions of occupying the entire railroad from the coast to Tsinan-fu; that it had requested the withdrawal from the railroad area of all Chinese troops, and that it has declared that any opposition encountered from the Chinese authorities will be regarded as an act unfriendly to Japan and partial to Germany."

By this method Japan sought to drive the "mailed fist" policy of Germany from China in order that she could replace it with the "mailed fist" policy of Japan, which has been modeled after that of her former Teutonic tutor in arms.

In no position to resist the Japanese demands, and with everything to lose by defying her powerful neighbor, China was forced to be humiliated and accede to seeing her neutrality violated. It was but another example of how 


\section{THE FALL OF TSINGTAU}

Japan tries to promote cordial relationship between China and herself. Japan was taking another step toward realizing her desire to dominate China. 


\section{CHAPTER II}

\section{PRELIMINARIES TO THE DECLARATION OF WAR}

IN a war, such as Europe was thrown into, there is no neutral territory to feel so much the concussion as the Far East. With practically all the Powers holding concessions in some part of the Orient, a diplomatic eruption in any other section of the world at once throws the foreign sections of the Far East into excitement.

The rising war clouds find Americans, Britishers, Germans, French, gathered together in the lobbies of hotels or at their respective clubs, all prophesying and discussing together the pros and cons of the question. By the time the actual declaration of war is served, the Far East is already at sword points, and the once cosmopolitan gatherings have become a clique affair with the Britishers at their club, the Germans at theirs, the French at their quarters, and the Americans free to go to whichever their membership entitles them to. 


\section{THE FALL OF TSINGTAU}

And then the war starts - in the actual field of battle by the deep undertoned voices of siegers and the phut-phut of rifles; in diplomatic centers by column after column of communications for publication to the editors of the various foreign newspapers. The British Resident in Shanghai writes a communication denouncing the German and his methods, to which the Germans promptly reply. Other foreigners take sides and join in the "communication" battle, and gradually the fight broadens. Before the battle is half over the editor finds himself swamped with mail and a truce is therefore declared. But by this time the political, the commercial, the religious, and in fact every side of life of the "warring nations" has absorbed the discussion and there is little left for the fighters to do but to hold their chagrin for distribution among their fellow nationals, and to watch and await developments from the actual field of war.

In such a condition was the Far East during the first week of August, 1914. With the European Powers at war with each other, there was a hasty call for reservists throughout the 


\section{PRELIMINARIES}

Orient. Immediately there was a rush, business was dropped, and everybody journeyed to the railway stations or to the piers to see the farewell of departing troops. In Yokohama and Kobe were great crowds of Japanese at the stations shouting "banzai" and waving a "sayonnara" to their departing French, British, Austrian, and German friends, who were all going over to Europe on the same boat to fight each other. And Shanghai and Hongkong witnessed like scenes with the enmity showing a little more bitter by the gathering in cliques: Germans on one side of the pier or on one side of the deck - the British on the other.

It was the publication in the foreign press of Japan, on August 4, of the reported seizure of the Russian volunteer fleet steamer Riazan, by the German cruiser Emden, from Tsingtau, which first bristled the back of the Far East with talk of actual war within its boundaries. The capture, so the report stated, took place near the Korean archipelago, while the steamer was on its way to Vladivostok, and as such was considered a heavy blow to Japanese sovereign rights and neutrality. 


\section{THE FALL OF TSINGTAU}

Whatever may be the truth of this reported German interference with trade in the Orient, the fact is that the Foreign Office at Tokyo had already seen in Germany's war against Europe a most opportune time to pay back that "grudge" against Germany for the part Berlin had played at the close of the Chino-Japanese War, in forcing Japan later to renounce the definite possession of the Liao-tung Peninsula, her fruit of the war. Then, too, the European war gave Japan an exceptionally favorable opportunity to realize her ambitions for the last ten years - the domination and control of China, and with England, Germany, Russia, and France all busy at home, there would be no Power left to check Japan but the United States.

It was not, therefore, a surprise to those foreigners who resided in Tokyo to learn on August 2 that the Foreign Office at Tokyo had sent a formal note to the Foreign Office in London in regard to the Mikado's willingness at once to put in force the Anglo-Japanese Alliance, which was negotiated in July, 1911. The note from Japan specifically referred to 


\section{PRELIMINARIES}

Article II of the Alliance, which stated: "If by reason of an unprovoked attack or aggressive action, wherever arising, on the part of any other Power"; or, if "either of the High Contracting Parties should be involved in war in defense of its territorial rights or special interests, the other High Contracting Party will at once come to the assistance of its ally and will conduct the war in common and make peace in mutual agreement with it."

Japan's offer to London to join in the European war by banishing the German menace from the Far East, signalized the approach of exciting and busy days in diplomatic circles of the Nippon Empire.

Scarcely had the note been handed to Sir Conyngham Greene, the British Ambassador to Tokyo, than the French Ambassador, Eugène L. G. Regnault, and the Russian Ambassador, Nicolas Malewsky-Malewitch, drove up to the compound of the English Embassy in Tokyo where an exciting discussion was held with the British Ambassador as to the practicability of allowing Japan to enter the war.

The conferences of the three ambassadors 


\section{THE FALL OF TSINGTAU}

was continued for three or four days, but just what stand was taken by the representatives was never known, except that harmony must have been reached, for on August 7 the British Ambassador handed to the Foreign Office at Tokyo a request that Japan join in the European war.

The exact contents of the note were never made public, but the rumor in diplomatic circles in Tokyo the following day had it that England had asked that Japan, in case she joined in the war, should confine her war operations to the actions of the German and Austrian warships, and to the protection of British merchantmen in Far Eastern waters, or to the negative help to British warships in Oriental waters.

Japan, it appears, was not content with restricted action, since she was to participate in the war under the terms of the Anglo-Japanese Alliance, but desired rather to play a more important part in the war operations than were proposed for the Far East.

On the same evening that the British Ambassador handed the Foreign Office in Tokyo 


\section{PRELIMINARIES}

the request from Sir Edward Grey, Count Okuma, Premier of Japan, called a meeting of the Cabinet which did not break up its session to well beyond 2 A.M. the following morning. At that meeting it was decided to go further into action in the Far East than to control the Pacific waters and aid British merchantmen and British warships; instead, to drive Germany from Kiaochow and Asia.

With this in mind, Baron Kato, Foreign Minister, proceeded the same morning to Nikko to advise the Emperor of Japan of the situation. At the same time an important conference was held at the Navy Office in Tokyo, at which Vice-Admiral Yashiro, Minister of Marine, Fleet Admiral Togo, and other prominent officials of the Navy Department conferred upon the possible part the Japanese fleet was to play in Oriental waters.

Germany at this time began to scent danger in the Anglo-Japanese Alliance and its possible effect upon Kiaochow and her other colonial possessions in the Pacific, and so on August 8 the German Embassy issued the following communique stating the relative position of the 


\section{THE FALL OF TSINGTAU}

German Far Eastern fleet with Japanese commerce:-

It will be of interest to learn that the German authorities have taken proper measures to avoid all unnecessary interference with neutral shipping, especially Japanese. Thus it is known that the German cruiser Emden, when meeting the Japanese steamship, Sakaki Maru, in hazy weather, requested her to show her flag in order to ascertain her nationality, and, when this request was complied with, immediately allowed her to proceed, observing all the usual courtesies.

Great Britain, now being advised of Japan's desires of pushing Germany out of Asia, began to hesitate in approving the start of Japan's war operations, and this led naturally to a delay in Japan's declaration to the world of her actions. The question that seemed to interest the Foreign Office in London was whether or not, if Japan drove Germany from Asia, Kiaochow should be placed under the control of Great Britain or of Japan.

Japanese diplomatists evidently decided that they should be supreme, for already their Government had mobilized an army of 25,000 men, transports had been hired, and the vessels of the Japanese navy, which were later to 


\section{PRELIMINARIES}

blockade the Bay of Kiaochow, were already at their yards at Sasebo, Kure, and Yokosuka, coaling, loading with ammunition and supplies, and preparing for the first move - in case war should be declared against Germany.

Meanwhile notes were being exchanged between London and Tokyo upon the issue at stake - whether Kiaochow at the conclusion of the European war was to be given to Great Britain to do with as she pleased, or should pass into the hands of the Japanese Empire. With Germany busy warring in Europe and unable, therefore, to offer her colonies in Asia and the Pacific any assistance, there was no thought in the minds of London officials that the little German garrison at Kiaochow could show any substantial resistance against the overwhelming odds that Japan would put against it - if allowed to carry out her desires.

The Foreign Offices at London and Tokyo, evidently being deadlocked upon the question, matters took a more favorable turn when Sir Edward Grey addressed a note to Japan in which he stated that Great Britain would grant 


\section{THE FALL OF TSINGTAU}

Japan's wish - to drive Germany from Kiaochow - provided she "would confine her war operation to the China Sea" and "eventually turn over Kiaochow to China."

In this move of depriving Germany of her Far Eastern naval base, Great Britain saw an opportunity of furthering her immense trade in China at the expense of Germany, at the same time depriving German commerce of a great asset in Asia. It sounded the death-knell of the "mailed fist" in Asia and, as Great Britain thought, would eventually see the restoration of Kiaochow to China, its rightful owner.

The British note, under the new terms, being delivered to Japan, the Nippon capital at once took on busy conferences. First, the Elder Statesmen and the Cabinet conferred, then the War Office was consulted, and at length, on August 9, Sir Conyngham Greene, the British Ambassador, was notified that Japan was ready to carry on the war against Germany according to the last note.

In the evening of the same day Count von Rex, the German Ambassador in Tokyo, was notified informally that a breach between the 


\section{PRELIMINARIES}

two Governments was pending. In fact, with the happenings that had occurred in Tokyo for the past several days, the German Ambassador had not been long in scenting danger, and days before had notified Berlin, as well as the Kiaochow Government, of the fast approaching war clouds in the Orient. His government had therefore acted accordingly.

On August 1, the day that Germany declared war upon England, the Norddeutscher Lloyd liner, Prinz Eitel Friedrich, which had called at Shanghai, on its voyage to Bremen, was notified by the Berlin Government to disembark all passengers and to proceed at once to Tsingtau. The following day it arrived at the Shantung port, and on August 3, Tsingtau was declared under martial law.

The British steamer, Kanchow, which was in port, was notified late that evening that she would have but two hours to leave the port or she would be seized. She moved out at once. Early the following morning Britishers, Russians, and Americans summering at Tsingtau awoke to find the city posted with proclamations. Every train running into the city 


\section{THE FALL OF TSINGTAU}

brought handfuls of German reservists from Tientsin and other cities in the hinterland, and all business in the city seemed to have ceased; instead there were preparations for war. ViceAdmiral Meyer Waldeck, Governor of Kiaochow, issued shortly afterward a note informing all non-combatants that they would be given a twenty-four-hour notice to leave. That evening, however, found the train running from Tsingtau to Tsinan-fu packed with foreigners as well as Chinese, all greatly excited and hoping to get out of Kiaochow before the war broke.

During this time quite another scene was being enacted in the harbor of Tsingtau. On August 3, the Prinz Eitel Friedrich, which had rushed from Shanghai two days before with her full speed of eighteen knots, was in Tsingtau being converted into a battle cruiser. Searchlights were placed on the vessel and the gunboats Iltis and Tiger, which stood alongside, were quickly stripped of their guns to be mounted on the faster boat. In the greater harbor lay the gunboats Jaguar and Lucks, with sailors busy about their decks dismantling the vessels of guns and war equipment. With the 


\section{PRELIMINARIES}

exception of these ships the only other warvessel in port was the Austrian cruiser, Kaiserin Elisabeth. All Tsingtau now seemed to be preparing for war and the busy and mysterious way the German residents went about the city quickly threw into panic the Chinese coolies of Tapautau, the Chinese section of the city, and many began to leave the district. Prompt action was taken by the German authorities however, who brought back two hundred coolies under guard and set them to work helping to dismantle the gunboats and equipping the Prinz Eitel Friedrich.

Likewise were other war operations carried on about Tsingtau. Along the fortifications that skirted the woods on Iltis, Bismarck, and Moltke hills in the rear of the city, members of the German Landsturm stationed in Tsingtau were busy mounting machine guns and artillery. The German freighters Longmoon, Gouverneur Jaeschke, and Stattssekretaer Kraetke had been requisitioned as colliers by the Government, and after entering port and coaling had gone out upon the Yellow Sea twenty miles to where the Emden, Scharnhost, and 


\section{THE FALL OF TSINGTAU}

Gneisenau were standing ready to fight or retire into the harbor, according to the strength of the enemy. At the same time Chinese junks heavily loaded with crates and boxes made their way down the Yang-tse River from Haicheng and interned at Tsingtau. Then started the long file of coolies from the piers to the military warehouses and fortifications with the crates on their backs.

Tsingtau was preparing for war - the war clouds had gathered so quickly that she found herself unprepared, with the result that powder, shells, and ammunition were being brought into the port from somewhere in the hinterland of northern China. British residents in Tsingtau, seeing these war preparations under way, became uneasy, and on August 7 more than sixty left the city for Peking. On the same day the Governor-General had the following notice posted throughout the city:-

All British nationals are allowed to continue to reside at the port and engage in their business as hitherto if they will give their word of honor through the British Consul not to engage in any acts which may be regarded as inimical to the German Empire. 


\section{PRELIMINARIES}

At Hongkong quite the same warlike scene was being enacted as at Tsingtau. August 1 found the city seething with excitement over the secret preparations that were being made to guard the city against attack. Throughout the previous night British-owned launches in the harbor had been steaming to and from the naval jetty, with all lights out, and heavily loaded with ammunition, stores, and guns. In the harbor was H.M.S. Triumph and the Canadian Pacific liner, the Empress of Asia, which had been requisitioned by the Government and was mounting guns over her sides. All the British river gunboats on the Yang-tse had been recalled and the crews paid off and commissioned to the Triumph. Large red handbills placarded the naval yards announcing to service men that divulgence of what was progressing meant seven years' penal servitude. The British bluejackets were confined to the dockyard, the troops to their barracks, and none were allowed to leave the place. Sentries were placed at every outpost boundary to guard the four hundred square miles of the colony, while the Royal Garrison Artillery and 


\section{THE FALL OF TSINGTAU}

the Hongkong and Singapore battalions were stationed at the posts on the Peak. Within the city the Governor of Hongkong journeyed throughout the centers of employment, addressing the workers at noon-day meetings and urging all able-bodied men to join the volunteers or reserves.

In this way, with sentries at attention armed with rifles and fixed bayonets, did the war clouds from Europe arise from the Pacific to greet the British settlement of Hongkong.

On August 10 war rumors which had been circulating throughout the Orient for the past two weeks, took decided form when Count Okuma called all journalists in Tokyo together for a conference at his home. At the appointed hour more than one hundred newspapermen were in attendance to listen to the remarks of Japan's veteran statesman. It was the writer's fortune to be one of the listeners at the conference, and to hear Count Okuma go over the war situation then existing in Europe. He broached the situation as it related to the United States and denounced as "false" the report, printed throughout the vernacular pa- 


\section{PRELIMINARIES}

pers a few days before, in which it was stated that the United States had dispatched a note to the Japanese Government in regard to its proposition to join in the European war. The report further stated that the Atlantic fleet was being rushed through the Panama Canal to Japan to back up the note.

"How can the United States make such an interference," said the Premier, "when Japan has practically done nothing in reference to the present war? Besides, judging from the holiday ${ }^{1}$ of the United States, and the traits of her people, no one will believe in such an allegation of the American intervention with Japan's attitude."

Count Okuma then laughed at the fear of the alleged approach of the American navy and advised the Japanese journalists to read Congressman Hobson's book on the United States before being disturbed by any thoughts of America.

Lieutenant-General Oshima, Vice-Minister of War, Rear-Admiral Suzuki, Vice-Minister

${ }^{1}$ Meaning in Japanese interpretation that the United States is at peace with the world. 


\section{THE FALL OF TSINGTAU}

of Marine, and Mr. Matsui, Vice-Minister of Foreign Affairs, in turn addressed the gathering and each hinted at the approaching war with Germany. The pressmen were notified that in the future no news about the movement of the Japanese fleet or its army could be printed without fear of the suppression of their papers by the Government. That evening the torpedo boats Kiji and Kamome were guarding the harbor at Yokohama, while a Japanese fleet under the command of Admiral Kato had put to sea and was sailing in the direction of Formosa.

For the next five days about Tokyo the Elder Statesmen, the Cabinet, the War and Navy Offices and the Foreign Office were busy in completing the final negotiations for the entry of Japan into the war. The Admiralty, to safeguard the actions of its fleet and army from the outsider, had issued drastic censorship regulations for newspapers. On the first days of its issuance several newspapers were suspended for publishing the whereabouts of the fleet or troops. On August 15 tha Emperor of Japan with the Empress repaired from his summer 


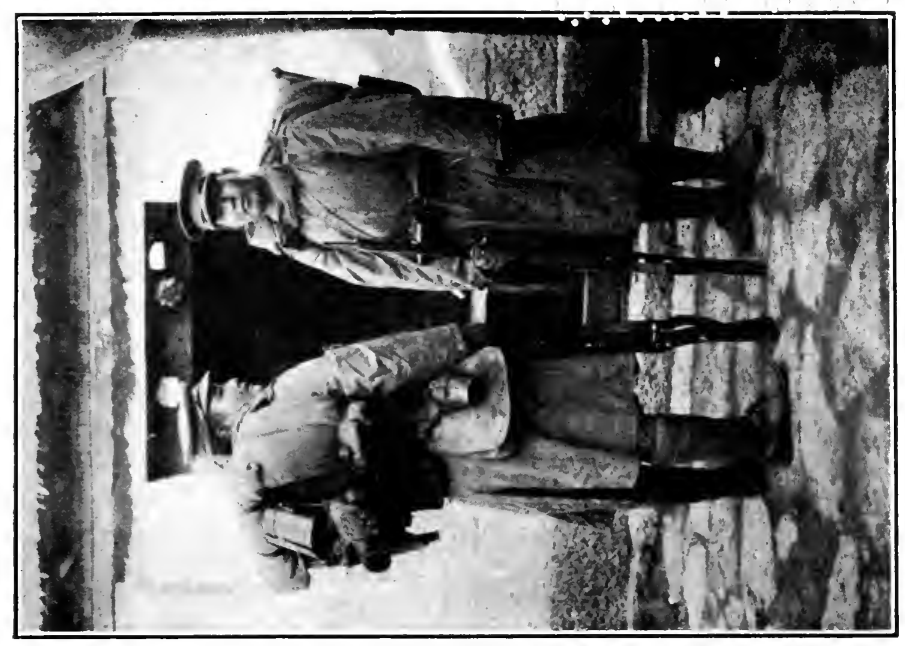

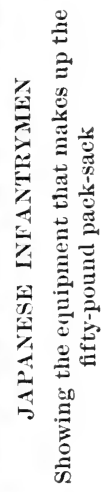

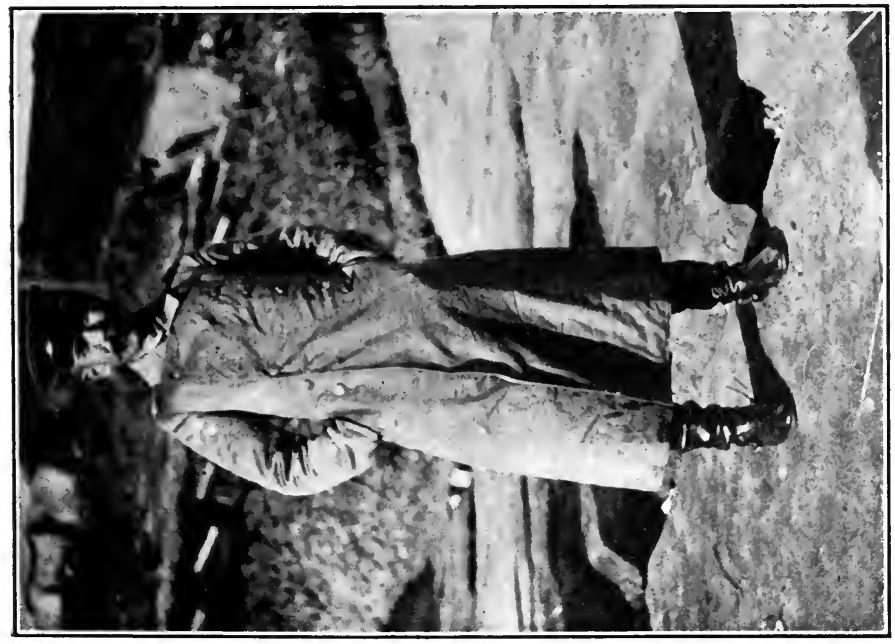

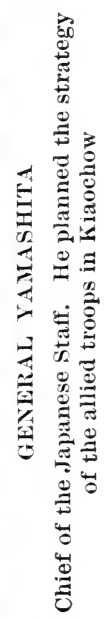


96 ma

48940 


\section{PRELIMINARIES}

residence at Nikko to the Imperial Palace at Tokyo, where late that afternoon the Elder Statesmen, as well as the chiefs of the General Staff and Naval Board, assembled before the throne to confer with His Majesty upon the Far Eastern situation and to arrange for the official rescript announcing the declaration of war upon Germany. The session before the Imperial Throne lasted until 7 in the evening, and but a few minutes later, Count von Rex, the German Ambassador, was presented with the following note: -

The Imperial Government, in view of the present situation, deems it important for the permanent peace of the Orient to see that causes of disturbance of peace in the Far East are removed and to take steps to protect the general interests of the AngloJapanese alliance. So, herewith the Imperial Government makes the following demands on the German Government: -

1. The German war-vessels shall at once withdraw from the waters of Japan and the China Sea. Those vessels which cannot withdraw shall be disarmed.

2. The German Government, with the object of its return to China, shall hand over the leased territory in Kiaochow to the Japanese Government on or after September 15 without condition and without compensation. 


\section{THE FALL OF TSINGTAU}

If a reply, agreeing unconditionally to those demands, is not received by noon on August 23, 1914, the Japanese Government shall take whatever steps it deems necessary.

A few days after the deliverance of the ultimatum, Count Okuma called a conference at his residence of the business and commercial heads of Japan. The writer attended the conference with a Japanese interpreter and the following is part of Count Okuma's declaration made that day. The reader will note that the Japanese Premier states that the Japanese participation in the war is for no "territorial aggrandizement," nor for any other "selfish end," and also that the Government will take no action to give other Powers "any cause of anxiety or uneasiness regarding the safety of their territories and possessions." The Premier spoke as follows: -

Japan's object is to eliminate from the continent of China the root of the German influence which forms a constant menace to the peace of the Far East, and thus to secure the aim of the alliance with Great Britain. She harbors no design for territorial aggrandizement nor entertains any desire to promote any other selfish end. Japan's warlike operations will not, therefore, extend beyond the limits 


\section{PRELIMINARIES}

necessary for the attainment of that object and for the defense for her own legitimate interests. Accordingly the Imperial Government have no hesitation in announcing to the world that the Imperial Government will take no such action as to give third Powers any cause of anxiety or uneasiness regarding the safety of their territories and possessions.

On the same day the Japanese Government sent the following communiqué to the Foreign Office of Peking:-

Owing to the aggressive actions of Germany, unfortunately a war has been started between England and Germany and the peace in the Far East is about to be disturbed. The Japanese Government, after consultation with England and considering the present circumstances and the future of the Far East, has been obliged to take this last course for the assurance of peace of the Far East and the preservation of China's territorial integrity and the maintenance of peace and order in the same country.

Just what the Kaiser thought of the Japanese ultimatum can be gathered from the fact that two days after its deliverance Count von Rex, the German Ambassador in Tokyo, with his legation staffs, started to pack their belongings initial to final leave-taking. War between 


\section{THE FALL OF TSINGTAU}

the two countries, he knew, was inevitable. Only the German Ambassador at Peking held out hopes that the German ruler would not be humiliated by its tone, and he started a vain negotiation with the Berlin Government for the transfer of Kiaochow to China.

But this action of Japan's I cannot understand [said Mr. Buttmann, of the German Embassy, when I called upon him a few days later]. Who is it that is hostile to the power of Japan in the Far East? It certainly is not Germany. It is none other than Russia who is still looking for a harbor that is not ice-bound, and where she can carry on her commerce.

Of course the whole war is nothing but political nonsense, and the jealousy of Great Britain over the fast-growing German navy is what has led to this conflict in which practically all Europe is involved. It had been the hope of German government offcials to form some sort of alliance with Great Britain, in which one Power supreme on sea, and the other Power supreme on land, could thus combine to maintain peace throughout Europe. But the English politicians in their narrowness would have none of it and they were bound to keep the English navy supreme on sea. The German navy has seen a wonderful growth in the past few years, but for every ship they built England built two.

Then, too, Great Britain has shown her narrowness again by combining with the Slav to fight her own race, the Teuton. But Russia drew them on, 


\section{PRELIMINARIES}

for Russia saw in supporting Servia her chance to extend her power into the Balkan States and possibly Austria-Hungary. And that is why Germany sent a note to Russia at the beginning of the conflict asking her to stop mobilization, for if Russia extended her sway into Austria-Hungary it would be but a step into Germany, and that would be her aim. But Russia refused to end her mobilization, and so with the mobilization of the German troops France was brought in. With revenge for AlsaceLorraine still in her mind, France realized that with her rise or fall the question of who should dictate upon the Continent rested.

As to Germany and Kiaochow, that is not the big fundamental question that Germany has to contend with to-day. It is a mere nothing to them and does not loom up as anything vital at all. Kiaochow can really only be called a sentimental question as far as Germany is concerned at the present.

On August 19, Count von Rex received word from Governor-General Meyer Waldeck of Kiaochow that the Berlin Government had instructed him to defend Kiaochow to the last man. At the same time Berlin cabled the following message to America:-

Should Japan intend to take possession of Kiaochow it would frighten us as little as did England's attack on Africa. This is only a new maneuver on the part of England, and though painful it will have little influence on the campaign. Germany will be 


\section{THE FALL OF TSINGTAU}

obliged to refuse Japan's claim. If Germany thereby suffers any loss, she will take her satisfaction in other ways.

All that Count von Rex had expected from Berlin in reply to the Japanese ultimatum was vouched for four days later - Sunday, August 23 - when that memorable hour of 12 o'clock noon was reached and not a word from his Government. A few hours later he was handed his passports as well as the following Imperial decree announcing the declaration of war:-

We, by the Grace of Heaven, Emperor of Japan, seated on the Throne occupied by the same Dynasty from time immemorial, do hereby make the following proclamation to all Our loyal and brave subjects: -

We hereby declare war against Germany and We command Our Army and Navy to carry on hostilities against that Empire with all their strength, and We also command all Our competent Authorities to make every effort, in pursuance of their respective duties, to attain the national aim, by all the means within the limits of the law of nations.

Since the outbreak of the present war in Europe, the calamitous effects of which We view with grave concern, We, on Our part, have entertained hopes of preserving the peace of the Far East by the maintenance of strict neutrality. But the action of Germany has at length compelled Great 


\section{PRELIMINARIES}

Britain, Our Ally, to open hostilities against that country, and Germany is, at Kiaochow, its leased territory in China, busy with warlike preparations, while its armed vessels cruising the seas of Eastern Asia are threatening Our commerce and that of Our Ally. The peace of the Far East is thus in jeopardy. Accordingly, Our Government and that of His Britannic Majesty, after a full and frank communication with each other, agreed to take such measures as may be necessary for the protection of the general interests contemplated in the Agreement of Alliance, and We, on Our part, being desirous to attain that object by peaceful means, commanded Our Government to offer, with sincerity, an advice to the Imperial German Government. By the last day appointed for the purpose, however, Our Government failed to receive an answer accepting their advice.

It is with profound regret that we, in spite of Our ardent devotion to the cause of peace, are thus compelled to declare war, especially at this early period of Our reign and while We are still in mourning for Our lamented Mother.

It is Our earnest wish that, by the loyalty and valor of Our faithful subjects, peace may soon be restored and the glory of the Empire be enhanced. 


\section{CHAPTER III}

THE VIOLATION OF NEUTRALITY

IT was to be expected that while the German offensive movement in Belgium was developing, during the first month of the war in Europe, observers would center attention upon the countries in Europe, to the exclusion of all war events elsewhere. This accounts probably for the somewhat indifferent attitude that was taken toward the war that Japan was waging against the German protectorate at Kiaochow. However, the events in the Far East had primarily a more important meaning to America than events in Europe, for they brought to the fore Japan's seizure of the German islands in Pacific waters. In case Japan should ever war against the United States, these islands might play a very important part; for the once German possessions in the Pacific can be utilized as a block in the communication between the colonial possessions of the United States, namely, Hawaii, Guam, and the Philippine Islands. 


\section{THE VIOLATION OF NEUTRALITY}

While Japan had actually started her war operations against Kiaochow days before her declaration of war against Germany, the first event in the war was the blockading of the Bay of Kiaochow. On August 26, three days after the declaration of war, Vice-Admiral S. Kato, in command of the second Japanese squadron, consisting of the Suwo, Iwami, and Tango, which had been the Pobjeda, Orel, and Poltawa of the Russian fleet before their capture by the Japanese in 1905, steamed from their base on the island of Formosa and drew up in a semi-circle ten miles out from Tsingtau. Admiral Kato sent a wireless message to Governor Meyer Waldeck of Kiaochow asking that he receive a parlementaire from the Japanese Government to consider the surrender of the protectorate. The Governor of Kiaochow refused the request unless the desires of the Japanese Government were specifically expressed, whereupon the Bay of Kiaochow was immediately declared by the Japanese to be blockaded.

Days before the German garrison at Tsingtau had expected this development, and so after 


\section{THE FALL OF TSINGTAU}

calling in her Far Eastern fleet consisting of the flagship Scharnhorst, under command of Admiral von Spee, the Emden and the Gneisenau, the war-vessels were reprovisioned and dispatched from the Bay of Kiaochow on a raiding cruise which proved one of the most melodramatic of the war. Germany had learned her lesson from the Russians and she decided that she was not going to do what the Czar's commanders had done at Port Arthur during her war with Japan - allow the bottling-up of her fleet.

With the departure of Admiral von Spee's fleet from Tsingtau, the entrance to the Bay of Kiaochow was sown with more than five thousand mines behind which barrier steamed the disarmed Austrian cruiser Kaiserin Elisabeth, as well as the German destroyer, S-90.

For the next several days the war operations of both Japan and Germany were seemingly veiled. The first fleet of the Japanese navy, under command of Admiral K. Kato, was still steaming about Formosa and the China coast, evidently searching for German prey, while the British cruiser Triumph and the British gun- 


\section{THE VIOLATION OF NEUTRALITY}

boat Kennet, which were scheduled to join in the Kiaochow action, were cruising off Hongkong and Shanghai guarding the China coast from the approach of the German Far Eastern fleet. The latter, however, was cruising about the South Pacific islands, searching for British merchantmen and otherwise guarding the German possessions.

To the extreme north of the Yellow Sea were the Japanese transports steaming toward northern Shantung and bearing twenty thousand fighting men, all eager to put into effect "the game" of the Mikado's protectorate in China and the driving of Germany from Asia.

Within Kiaochow and Tsingtau final preparations were being made for the Japanese attack. With a permanent garrison of only sixteen hundred men, Berlin had issued a call for the reservists in the Far East to report at Tsingtau, and into the German protectorate they poured - from Singapore, Hongkong, Shanghai, Kobe, and Tokyo; every train from Tsinan-fu into Tsingtau brought its quota of Germany's finest men. The majority of the reservists were traders, men who had spent 


\section{THE FALL OF TSINGTAU}

years in the Far East in learning native languages and fostering German trade. By the first week in September there were about fortyfive hundred fighting men gathered about the fortifications of Tsingtau.

All were busy along the fortification walls that skirt the rear of the city. Trenches were being dug, the ground in front mined, redoubts with bomb-proof shelters constructed, barbedwire entanglements set up, and guns mounted. The garrison was expecting the landing of the Japanese land forces at any minute and the Tsingtau fortifications were alive with moving men both day and night.

But the German garrison of Kiaochow had seemingly forgotten, during their exciting preparations for war, that the Japanese diplomats are shrewd, and that even an army bent on war sometimes halts to gather fruit by the wayside. And so the German garrison worked hard and labored in preparation for news of the landing in Kiaochow of the Japanese expeditionary force and their advance upon Tsingtau, but the Japanese did not come.

Expectancy always kindles excitement. And 


\section{THE VIOLATION OF NEUTRALITY}

so it did in Tsingtau during the last week in August. At night the bright flares and flashes from the searchlights on the blockading squadron could be seen reflected like signals on the clouds that hung over the Yellow Sea, suggesting "to-morrow the attack" in the minds of the Tsingtau garrison. But the days came and went without much change in maneuvers.

One day, however, the blockading squadron approached within the nine-mile zone to the entrance to Kiaochow Bay, and then it was that the residents in Tsingtau heard the deep undertone reports of their twenty-four-centimeter guns on Iltis Fort and knew that the war in the Far East had actually started.

And the "to-morrow," - well, it came and with no signs of the approaching expeditionary forces, until, on September 3, the German garrison at Tsingtau received a report that the Japanese troops had landed at Lungkow, one hundred and fifty miles to the north.

The news was received with surprise and was instantly followed by the ordering of three detachments of the German troops into the hinterland of Kiaochow. One detachment, 


\section{THE FALL OF TSINGTAU}

called the eastern detachment, proceeded in the direction of Chinchiakow to guard the road to Chefoo; another proceeded to Kaomi to check the advance of the Japanese on the road from Lungkow; and the third, or western, detachment stationed themselves at Chucheng to guard the southern seacoast.

Beyond Lungkow, the Japanese army began to violate China's neutrality, which, at the opening of hostilities, they had guaranteed to uphold. With the troops already landed upon Chinese soil, and with the Peking Government too weak to carry on any aggressive action against Japan, no matter how much her citizens desired it, there was but one thing China could do - place a limitation upon the actions of the Japanese troops in northern Shantung. In this connection the Chinese Government on September 4 sent the following note to the foreign legations in Peking:-

The Government of China declared its neutrality toward the present European war and is faithfully maintaining it. According to reports from the Chinese local authorities in the province of Shantung, the Germans have commenced war operations at Kiaochow Bay and their sphere of influence 


\section{THE VIOLATION OF NEUTRALITY}

there, and the allied forces of Japan and Britain have also started war operations at Lungkow, Kiaochow, Laichow, and in their neighboring districts. Germany, Japan, and England are all in friendly relations with China, and it is to be regretted that unfortunately these Powers have taken such unexpected courses in China's territory, therefore the Chinese Government has decided to propose special limitations as regards the extent of the present war operations as China limited the scope of war operations at Liao-tung Peninsula at the time of the Ruso-Japanese War in 1904. The Chinese Government will not accept responsibility for the passing of troops or any war operations at Lungkow, Laichow, Kiaochow, and their adjacent districts, but in the other districts in China the Government will strictly enforce neutrality as declared. The territory and diplomatic negotiations of China are recognized by the Powers and they will likewise protect the property of the inhabitants in the region to be affected by the war operations.

Though Peking and all China looked with distrust upon Japan's actions, the Government issued a proclamation stating that "as Japan and England are coöperating in the attack upon Tsingtau at this time, in order to return Kiaochow to China, our people should show their good-wills toward them. If any Chinese officials should meet Japanese or British soldiers they should show their good-will toward 


\section{THE FALL OF TSINGTAU}

them, should act peacefully and avoid all conflicts. Should the Japanese or British soldiers come outside of the war zone, our soldiers and citizens should not act independently, but should await instructions from Peking."

On September 11, Japanese forces entered Tsimo, ninety miles from Lungkow, after battling nine days with heavy rains which flooded rivers and made the advancement of military operations practically impossible. The roads were mere quagmires in which the heavy military carts sank to their hubs.

From Tsimo the troops pushed on to Weihsien, again going out of the defined war zone and violating the neutrality of China.

This last action seems to have been the straw that broke the camel's back, for all of northern China rose in revolt against the Japanese action. The Japanese troops took command of the Shantung railroad, shooting down native employees who seemingly rebelled at the invasion. The troops pushed on to Tsinan-fu, leaving small garrisons in every Chinese town to keep "Japan's peace," and in a few days western Shantung was practically in the control of Japan. 


\section{CHAPTER IV}

THE ADVANCE OF THE JAPANESE ARMY

ON September 11, while officials in Peking were still discussing Japan's violation of China's neutrality, the Imperial Japanese army with its cavalry arrived at Pingtau, about forty miles from Tsingtau. There had been no sight of the enemy, but reports were current that a detachment of Germans were garrisoned in the little city of Tsimo, about twenty miles distant. The same night the troops advanced toward Tsingtau, and on the following morning the first encounter of the war with Germany took place at Tsimo.

The little German garrison, consisting of but ten men, was driven off easily after an exchange of a few shots, in which two of the Germans fell wounded and Tsimo, a Chinese city of thirty thousand population, passed into the hands of Japan. The Japanese army officers, to soften the hostile feeling of the Chinese residents against them, at once journeyed to 


\section{THE FALL OF TSINGTAU}

the shrines of Confucius, devout Shintoists and Buddhists as they were, and knelt in prayer before the great philosopher of the Celestial Kingdom. In this way did the Japanese army officers gain the respect of the Chinese natives in Tsimo.

While these warlike events were taking place about Tsimo, Tsingtau was suddenly thrown into great confusion by the flight of a Japanese aeroplane over the city dropping bombs. The aeroplane, which was attached to the blockading squadron, had previously made one or two reconnoitering flights over the Tsingtau fortifications, but had confined its actions simply to observation. The gaping holes in the roofs of the Moltke Barracks and Governor Waldeck's residence, which marked the damage done by Japan's first use of the aeroplane in modern warfare, put the residents of Tsingtau in great excitement. From then until the first week of November and the siege of Tsingtau, the little city lived in an atmosphere of trembling expectancy.

With the "game" in the landing of troops at Lungkow now fulfilled, - the occupation of 


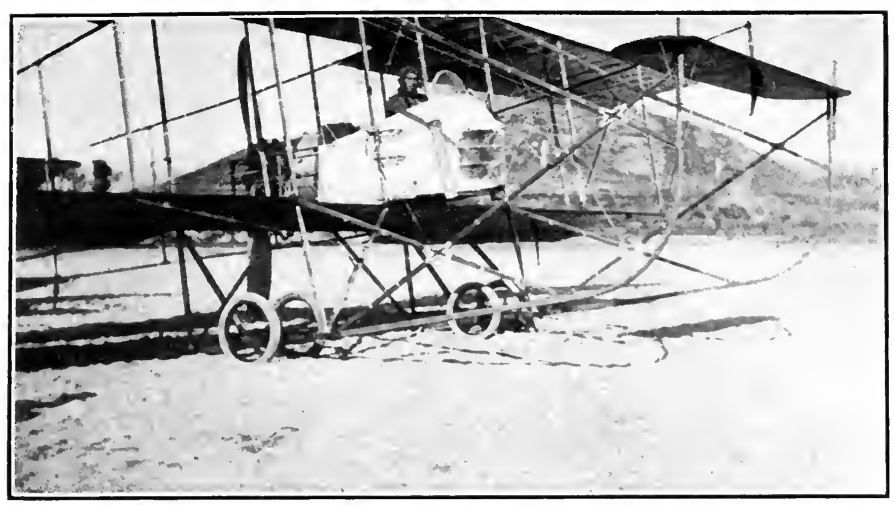

JAPANESE AEROPLANE

Preparing for a tlight over the city of 'Tsingtau from its base along the Tschangtsun River. The long tubular bomb-carrier can be seen on each side of the aviator's wind-shield

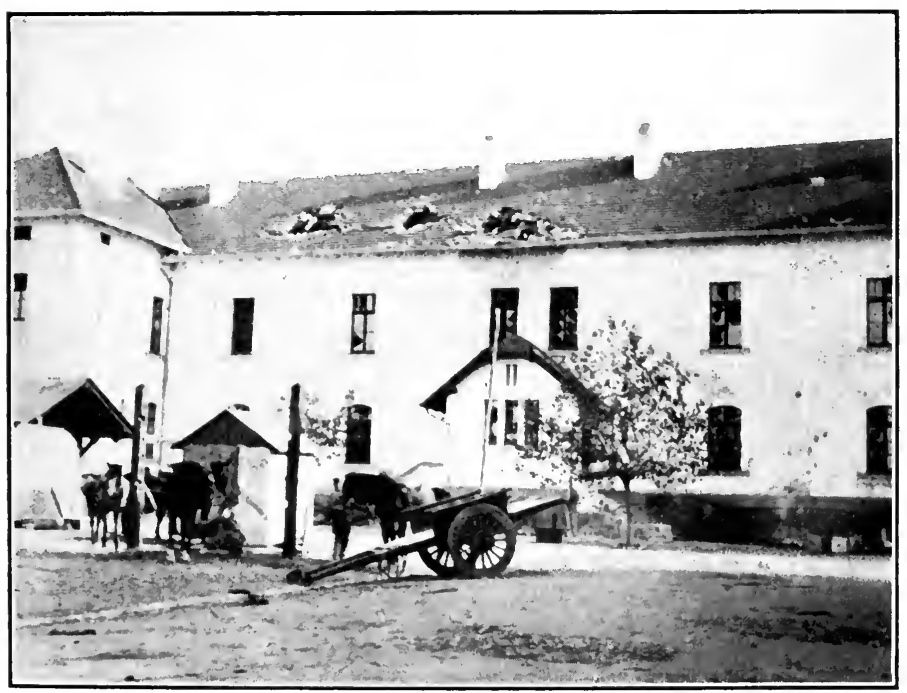

THE MOLTKE BARRACKS AT TSINGTAU

The roof shows the work of bombs from the Japanese aeroplanes. The concussion from the guns in the near-by forts had shattered every window 
술 


\section{ADVANCE OF THE JAPANESE ARMY}

western Shantung, - Japan now set about to bring her war operations to a close in the brushing of Germany from Asia. The first step taken toward this end was in the transferring of her base of supplies from Lungkow, one hundred and fifty miles from Tsingtau, to Lauschan, but fifteen miles from the German city. The district lies just without the limits of Kiaochow and, having a large bay, well sheltered by the Lauschan Mountains, which rise up in the Yellow Sea at its southern end, it furnished an ideal location for a base of supplies.

On September 14, Commander Aoki, in command of the destroyer flotilla before Tsingtau, forced a reconnoissance into Lauschan Bay and drove back the handful of German sentinels that were posted about the district. The following day other units of the blockading squadron were brought into effect at Lauschan and within a few days Japanese transports appeared in the bay bearing fifteen thousand additional troops.

Siege guns were unloaded, ammunition and supplies of all kinds, as well as several aero- 


\section{THE FALL OF TSINGTAU}

planes and portable wireless outfits, and soon Lauschan was a bustling little war-city. Chinese coolies of the district were forced into service and work was started on the construction of a narrow-gauged railroad into the hinterland to carry supplies to the attacking army.

Tsingtau by now was practically cut off from all communication with the world. The Shantung railroad had been cut by the Japanese army and troops had already entered the Chinese city of Kiaochow, outside the protectorate. The Tsingtau cable line had been cut, and only the wireless in the rear of Governor Waldeck's residence remained as a source for news of anything happening outside the little protectorate. Through messages transmitted by wireless from German vessels anchored at Woosung, near Shanghai, Tsingtau was able to get a few scattered messages of events in the European situation, but these were meager and only served as an appetizer for more. Japanese aviators had on one or two occasions tried to destroy the Tsingtau wireless station by bombs, but only once did the effort prove effective, and then the damage 


\section{ADVANCE OF THE JAPANESE ARMY}

done was repaired in a few days by the Germans and communication was again opened.

On September 18, the Japanese troops which had landed at Lauschan advanced into the hinterland eight miles, where they suddenly met with resistance from a detachment of about one hundred Germans who had strongly fortified themselves in one of the mountainous passes, behind machine guns. No casualties were suffered in the fighting, but the Germans were forced to retreat toward Tsingtau.

On the same day Captain Zenji Sakuma, of the Japanese cavalry corps, was killed in a skirmish of his force with an advanced guard of Germans near Liuting on the river Paisha, the western boundary of Kiaochow. It was the first Japanese casualty of the war. In the same engagement Baron Leadsell, second secretary of the German Legation at Peking, was also killed.

For the next two weeks there were many clashes and skirmishes between small detachments of the two opposing forces, and all tended to the gradual retreat of the Germans toward their fortifications at Tsingtau. 


\section{THE FALL OF TSINGTAU}

During the next week the Japanese army centered its fighting in the mountainous districts south of Lauschan and gradually the small German detachments were driven back toward Tsingtau. With the occupation of Sanpiaoshan Peak, nine hundred feet high, on September 22, the Japanese were able to secure a first-class observatory position, from which to view the movements of the German front line, four miles distant at Litsun and Shatsekau.

Two days later the attacking force was further strengthened by the landing of the British expeditionary force at Lauschan, under the command of Major-General Barnardiston. The British force consisted of the Tientsin garrison of South Wales Borderers, comprising nine hundred and twenty-five men with three hundred additional Sikhs. 


\section{CHAPTER V}

\section{CLOSING IN THE OFFENSIVE}

The war operations of the combined AngloJapanese force in Kiaochow, from the last week in September until the siege of Tsingtau late in October, offered little of interest to the outside reader, such as was furnished by the war raging in Europe. With a battle front of scarcely five miles, and with the German garrison at Tsingtau able to put only two thousand trained soldiers in the field, the fighting in Kiaochow during the above-stated period took the form more or less of mere skirmishes.

Governor-General Meyer-Waldeck at Tsingtau had scattered his trained force in small detachments about the hinterland, there to guard the roads and, if possible, hinder the advance of the Japanese troops, but so overwhelmingly were the odds against him that the resistance was very little.

From a military standpoint, however, the -maneuvering of the troops during these four 


\section{THE FALL OF TSINGTAU}

weeks had proved beneficial to the Japanese army, in that it gave the aviation corps a chance to show the value of the aeroplane in modern fighting. It was the first time the Japanese army had ever utilized the air machine in their war operations. Five or six machines were in flight throughout the day marking movements of the Tsingtau garrison. Through this form of communication the Japanese staff officers were constantly in touch with the movement of the German field force, and gradually they were able to cut through the German front defense and force the latter to withdraw toward the Tsingtau fortifications.

Bringing the gunboat Jaguar and the Austrian cruiser Kaiserin Elisabeth up the Bay of Kiaochow, the Germans opened fire upon the advancing force, both from sea and land, in an effort to check the advance, but the Japanese retaliated by sending a bomb attack from their aeroplanes against the ships and gradually they were forced out of range of the land operations.

At the same time the fourth detachment of the Japanese blockading fleet before Tsingtau 


\section{CLOSING IN THE OFFENSIVE}

in the Yellow Sea advanced into the bay at the foot of the Lauschan range, and, after landing marines, forced back the left wing of the German defense line to within three miles of Tsingtau. Four old field guns, German trophies of the Franco-Prussian War, were all the spoils that the Japanese gained in the attack. The German outposts in the mountains, however, before withdrawing, applied the torch to Mecklenberg Inn, a mountain summer resort for the Tsingtau residents, and destroyed all the bridges in the mountain gorges that the German Government had built in constructing the macadamized automobile road from the capital of the protectorate into the mountains.

In the same way did the German outposts along the Bay of Kiaochow hinder the advance of the Japanese army by dynamiting all railroad bridges and the like along the route of the Shantung railroad.

During this time Japanese trawlers were busy at work in the Yellow Sea sweeping the entrance to the bay of mines that the Germans had placed in the waters. The Tsingtau promontory forts all attempted to harass the work 


\section{THE FALL OF TSINGTAU}

by firing upon the trawlers, but the guns were not equal to the range and no damage was reported. A German aeroplane also made continuous flights over the vessels at sea, dropping bombs, and the Japanese retaliated by dispatching two hydroplanes in pursuit of the German air machine. In each such case the German machine easily outdistanced the Japanese flying corps and flew back in range of the Tsingtau fortifications before the Japanese aviators could head it off.

By October 12, the Japanese investing army, with the British expeditionary force making up the right wing, had advanced to Litsun, about eight miles from Tsingtau. Here the German front line seemed to take a stubborn stand and backed by the Kiaochow cavalry and artillery the fighting took on more desperate form. During the week the Germans were firing more than fifteen hundred shells daily from their field pieces and the Japanese casualties for the total operations had passed the two hundred mark.

So hot did the operations before Litsun eventually become that the Governor-General 


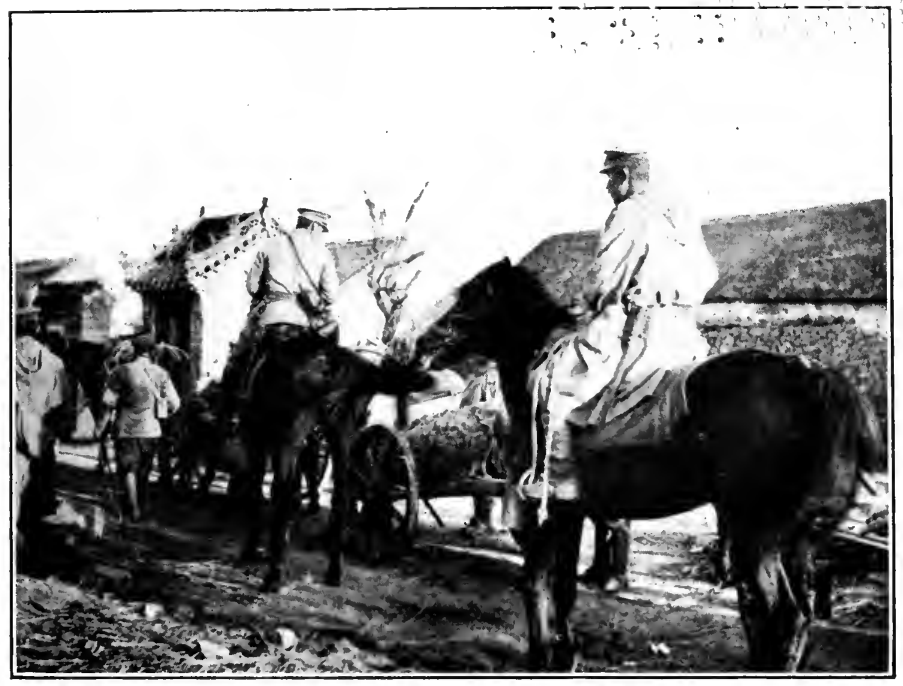

ON THE MARCH THROUGH A CHINESE VILLAGE IN KIAOCHOW

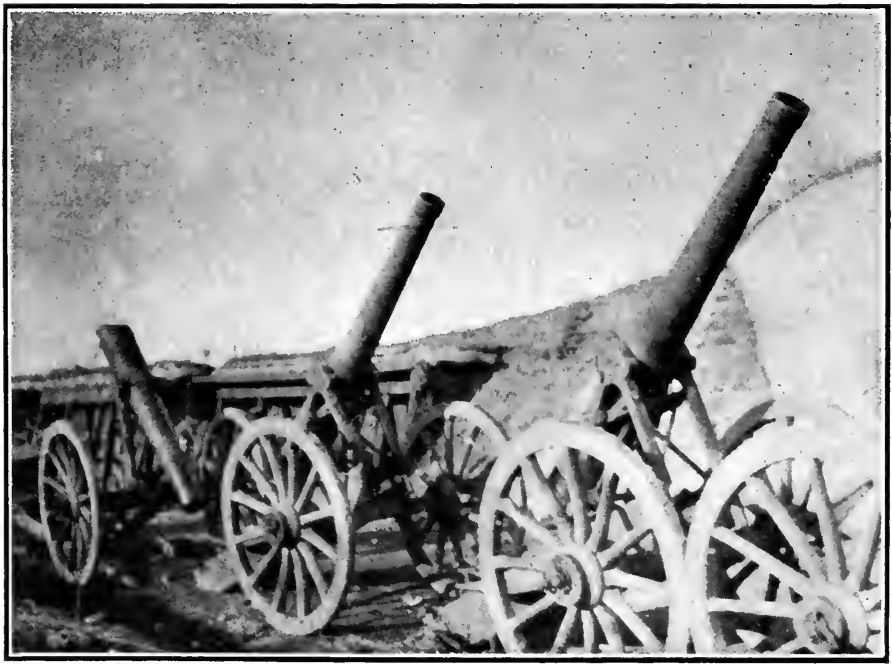

TROPHY RELICS FROM THE FRANCO-PRUSSIAN WAR

Used by the Germans in the defense of Tsingtau. Rather than leave them as useful prizes of war to the enemy, they blew the breech-block off each gun 


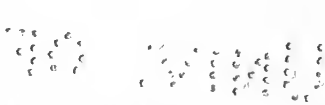

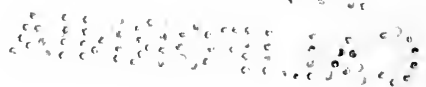




\section{CLOSING IN THE OFFENSIVE}

of Kiaochow forwarded a dispatch to General Kamio, commander of the investing force, asking for a suspension of hostilities in order that time could be taken to bury the dead. Just what were the German losses in the engagement is not known, but a few hours later, when the bombardment was resumed, the Japanese force in advancing came upon a trench with twenty-eight dead Germans, evidently overlooked by the Tsingtau garrison during the truce, and it is thought the German casualties for the day amounted to more than two hundred.

In preparation for the final investment of Tsingtau, however, the Japanese staff officers decided to notify all non-combatants in the city of the situation and, if possible, give them an opportunity to leave the war zone before the operations became more serious. In this connection the following communication was sent by wireless to Governor-General Waldeck at Tsingtau on October 10:-

The undersigned have the honor to convey to Your Excellency the most gracious wishes of the Emperor of Japan, who desires to save non-com- 


\section{THE FALL OF TSINGTAU}

batants of the belligerent country as well as the subjects of neutral countries at Tsingtau who desire to escape from the loss that may arise from the attack on the fortified port. If Your Excellency desires to accept the proposal of the Emperor of Japan, you are requested to furnish us with a detailed communique about it.

[Signed] Lieutenant-General Kamio. Vice-Admiral Kato.

A few days later the Kiaochow Governor notified his approval of the Japanese note and Captain Yamada, with ten Japanese soldiers, was sent to the gates of Tsingtau to escort the non-combatants who desired to leave the illfated city and the war zone. Only about a dozen persons desired to take advantage of the Japanese humanitarian note, one being Mr. Peck, the American Consul at Tsingtau, who had remained in the city to protect American interests, until notified from Washington to proceed to Peking. 


\section{CHAPTER VI}

THE GERMANS WITHDRAW TO TSINGTAU

Wiтн the field guns of the attacking force now thundering at the very door of Tsingtau, and with the final leave-taking of non-combatants, the little German city commenced to stir with excitement. Up to this time the city had not been cheered by any optimistic reports from the field of battle, but events shortly took on a different aspect when on the midnight of October 17 a report went circulating through the city that a Japanese battleship had been sunk outside the Bay of Kiaochow by the German destroyer S-90.

The report was true, but not until days later did the little German city learn the extent of the damage. It seems that the German destroyer, which was supposedly interned in the harbor of Tsingtau, had made its way out through the mined entrance to the harbor under cover of darkness and had attacked the Takachiho, a second-class defense boat of the 


\section{THE FALL OF TSINGTAU}

Japanese blockading fleet, which was doing outpost duty near Lauschan Bay. Suddenly the other units of the Japanese fleet, which were standing out at sea about nine miles, saw a flash, and a few minutes later the report of an explosion was heard. Putting on full speed, the vessels rushed to the aid of the Takachiho, but when they arrived in the waters they found the vessel already sunk and a few of its crew scattered about in the sea. As the relief ships approached they caught the sound of the Japanese national anthem, "Kimigayo," which the survivors were singing. Only one officer and twelve of the crew were picked up as survivors of the incident. Twenty-eight officers and two hundred and forty-four of the.crew had gone down with the vessel.

It was a sorry day for the Japanese navy, not only from the standpoint of the loss of its many officers, but because of the sinking of the vessel around which was wrapped so much historical sentiment. The Takachiho had been the flagship of the Japanese navy during the ChineseJapanese War, and as such had played a prominent part in the naval battles of that war which 


\section{GERMANS WITHDRAW TO TSINGTAU}

had left Japan supreme among Asiatic nations. It had also seen service at Port Arthur in the Russian war, and had come to be looked upon by the Japanese as the foundation of their present first-class navy, much as the American people regard the Constitution.

Following its successful attack upon the Takachiho, the German destroyer broke through the Japanese blockading squadron and, its movements unnoticed, cruised along the China coast to Shihsuehso, a Chinese port sixty miles south of the Bay of Kiaochow where the vessel was beached and disarmed by its crew. The crew was then placed under guard by Chinese soldiers, by orders from Peking, and was held at Nanking.

With the report of the escape of the S-90 in Japanese hands, the blockading fleet at once closed up on Tsingtau and started a bombardment upon the forts, from a point nine miles at sea. The British cruiser Triumph also joined in the action, but upon approaching within gun range of the Tsingtau promontory forts she received damage on her port side. One sailor was killed and several wounded in the attack. 


\section{THE FALL OF TSINGTAU}

In coöperation with the sea attack upon Tsingtau the investing land forces started their operations for the final investment of the city from land. One regiment started an assault upon Prince Heinrich Berg, a mountain rising one thousand feet, and but three miles from Tsingtau, on which a detachment of thirty Germans had been stationed. Barbed-wire entanglements had been placed on the mountain-side, already strongly fortified behind the rocky crags that characterized the cliff. The little German detachment was able successfully to hold its own for more than four hours. One Japanese major and more than fifty men were killed in the storming of Prince Heinrich, but by a coup a few of the regiment were able to gain the summit of the mountain from the rear, without their approach being noticed by the Germans, who, surrounded on all sides, laid down their arms and surrendered.

Following this incident the Japanese and British forces were sucidenly thrown into bewilderment by the disappearance across the Yellow Sea of one of the German observatory balloons from Tsingtau. The balloon, which 


\section{GERMANS WITHDRAW TO TSINGTAU}

corresponded to the type being used by the Japanese army from their rear line, was seen to contain the figure of a man using fieldglasses, and during the middle of October it was every morning above the Tsingtau fortifications. The attacking army had tried to reach the balloon with shrapnel, but the attempt had proved unsuccessful. Suddenly one day in a heavy wind the balloon, with its observer, afterwards learned to be a stuffed dummy, took to the air and went whirling across the sea. Japanese and British officers followed it with their glasses, wondering what the movement could mean, and it was several days before it was known to have been a hoax.

With the disappearance of their war balloon from Tsingtau, the German garrison was forced to rely upon its one Taube for information of the Japanese army movements. In all the heroic work of the German defenders in Kiaochow, probably no incident stands out more than the work of Lieutenant Pluschow, who, days before the Japanese army had approached to gunshot distance of the Tsingtau forts, was flying about the hinterland of Kiao- 


\section{THE FALL OF TSINGTAU}

chow spotting the movements of the opposing force. With only three months' training, he had taken charge of the German aircraft, and high in the air above the entrenched British and Japanese forces, he had braved shrapnel fire and shells from field guns in order to keep the German staff at Tsingtau acquainted with any changes on the battle line.

Back in Tschang-tsun, where was stationed, two weeks before the siege of Tsingtau, the headquarters of the Japanese staff officers, no alarm clock was needed to tell when daylight was rising from the Yellow Sea. Simultaneously with the first streaks of dawn in the east could be heard the whirr and hum of Lieutenant Pluschow's Taube as he set out from Tsingtau, and over the hills in the hinterland, to see what was stirring in the enemy's camp. Swooping low over the village of the Japanese staff officers, he dropped many a bomb upon the Chinese thatched roofs. The hum of the German aeroplane was the signal that a new day had arrived, and promptly the little village was astir, each of its residents hurriedly dressing and scanning the sky for the fast-disappearing 


\section{GERMANS WITHDRAW TO TSINGTAU}

Taube. Each day he visited the Japanese headquarters, and though, on occasions, a Japanese field piece, hidden behind some embankment, would try to cut short these flying expeditions, Lieutenant Pluschow was undaunted, and a few hours later would be back again flying over the village.

But the investing forces slowly pushed on their operations. There was not much hurry, not much excitement in their movements, for the Japanese staff officers, as well as the Tsingtau garrison, knew that it was only a question of time before Kiaochow would have to bow to the inevitable and be handed over to Japan. General Kamio, commander of the Japanese forces, knew that he was master of the situation, that Tsingtau was practically isolated from the world, and especially Germany, and that no aid could possibly reach the little protectorate.

And so the Japanese staff officers allowed events to progress slowly, not especially because it would lessen loss of life, but because the political situation, then developing in Japan, was very critical for the Tokyo Govern- 


\section{THE FALL OF TSINGTAU}

ment. The Cabinet, which in conjunction with the Elder Statesmen had shaped the policy that the nation was following in the war, stood in danger of falling, and with the Diet meeting in December to shape the Government's budget and to decide on other bills and measures, it was deemed necessary that the war operations should progress slowly until the right moment should present itself for bringing the Kiaochow issue to a close.

Under such a scheme the Government thought the successful culmination of its war operations would sweep the island nation with patriotism and the opposition to the Government at home would at once have to accede to public demand. In this way the Okuma Cabinet would remain in power after the Diet session, and would be able to further the policy that it had under construction when it first suggested to England that it be allowed to wipe out the German naval base at Kiaochow under the terms of the Anglo-Japanese Alliance.

A later chapter describes how the culmination of hostilities at Kiaochow brought on a serious political situation in Tokyo in which 


\section{GERMANS WITHDRAW TO TSINGTAU}

Japanese statesmen were forced to bow to public clamor and reveal their diplomatic insincerity, in order to remain in power and hold the Government's policy intact. 


\section{CHAPTER VII}

THE BEGINNING OF THE SIEGE

WAR from a grandstand seat! I had never before heard of the possibility of witnessing modern warfare - the attack of warships, the fire of infantry and battery, the reconnoitering of airships over the enemy's lines, the rolling up from the rear of reinforcements and supplies - all at one sweep of the eye, yet after watching for three days the siege of Tsingtau, from a position on Prince Heinrich Berg, one thousand feet above sea level and but three miles from the besieged city, I am sure there is actually such a thing as a theater of war.

On October 31, the anniversary of Mutsuhito's accession to the throne of Japan, the actual bombardment of Tsingtau began. All the residents in the little Chinese village of Tschang-tsun had been awakened early in the morning by the whirr of the German Taube as it made its usual inspection of the headquarters of the Japanese staff officers. Every one 


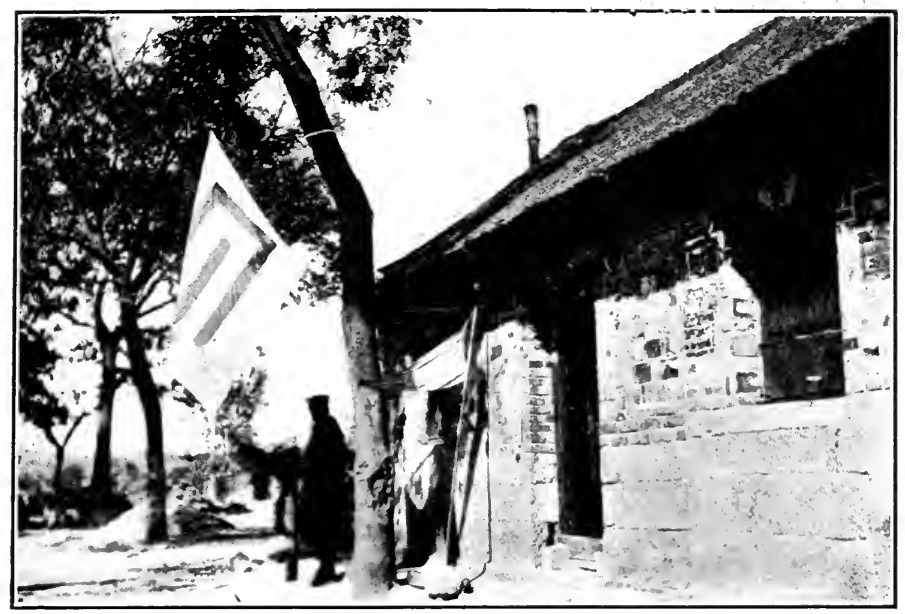

HEADQUARTERS OF THE GENERAL STAFF OF THE JAPANESE FORCES AT TSCHANG-TSUN

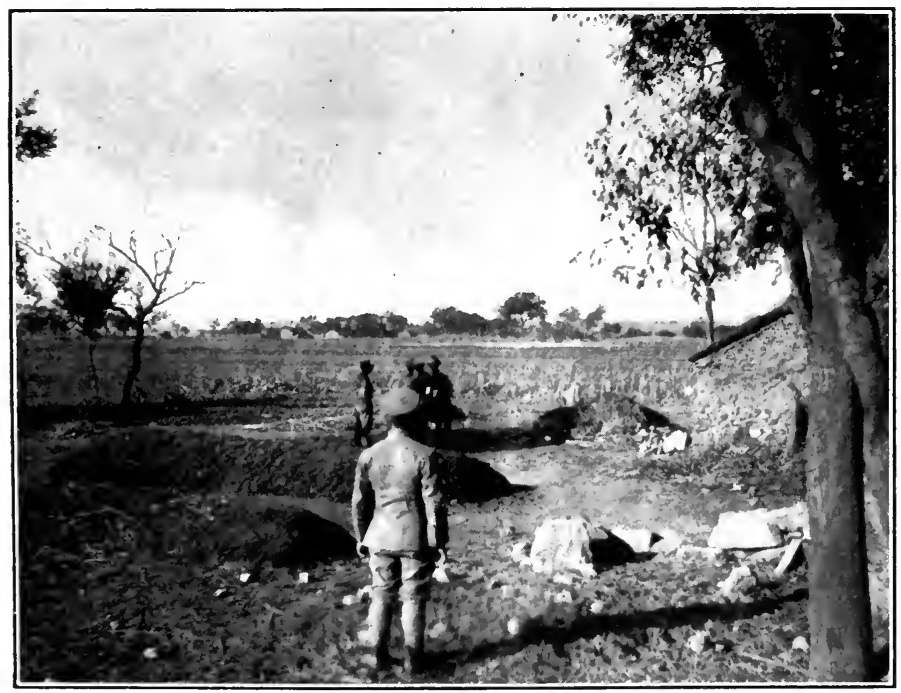

TSINGTAU ON THE MORNING OF OCTOBER 31

As it appeared from the Japanese Staff Office at Tschang-tsun, when the bombardment began. Japanese shells had fired the oil-tanks, and the smoke hung like a pall over the city throughout the day 


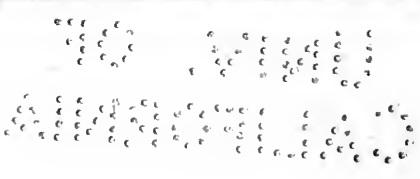




\section{BEGINNING OF THE SIEGE}

quickly dressed and after a hasty breakfast was out at the southern edge of the village gazing toward Tsingtau.

A great black column of smoke was arising from the city and hung like a pall over the besieged. At first glance it seemed that one of the neighboring hills had turned into an active volcano and was emitting this column of smoke, but officers who stood about enlightened onlookers by explaining that the oil tanks in Tsingtau were on fire.

As the bombardment of Tsingtau was scheduled to start early in the morning, we were invited to accompany members of the staffs of the Japanese and British expeditionary forces on a trip to Prince Heinrich Berg, there to watch the investment of the city.

When we arrived at the summit there was the theater of war laid out before us like a map. To the left were the Japanese and British cruisers in the Yellow Sea, preparing for the bombardment of Tsingtau. Below was a Japanese battery, stationed near the Mecker house, which the Germans had burned in their retreat from the mountains. Directly ahead was the 


\section{THE FALL OF TSINGTAU}

city of Tsingtau with the Austrian cruiser Kaiserin Elisabeth steaming about in the harbor, while to the right one could see the German coast and central forts and redoubts and the entrenched Japanese and British camps.

We had just couched ourselves comfortably between some large jagged rocks, where we felt sure we were not on a direct line with the enemy's guns, when suddenly there was a flash as if some one had turned a large golden mirror in the field down beyond to the right. A little column of black smoke drifted away from one of the Japanese "saps," or trenches, and in a minute later those of us on the peak of Prince Heinrich heard the sharp report of a field gun.

"Gentlemen, the show has started," said the British captain, as he removed his cap and started adjusting his "opera" glasses. No sooner had he said this than the report of guns came from all directions, with a continuous rumble, as if a giant bowling-alley were in use.

Everywhere the valley at the rear of Tsingtau was alive with golden flashes or the flashing from discharging guns, and at the same time great clouds of bluish-white smoke would sud- 


\section{BEGINNING OF THE SIEGE}

denly spring up around the German batteries, where some Japanese shell had burst.

Over near the greater harbor of Tsingtau could be seen flames licking up the Standard Oil and Asiatic Petroleum Companies' large tanks. We afterwards learned that they had been ignited from the huge shells that had been turned upon the tanks from the Japanese guns, and the bursting tanks had thrown burning oil on to the naval buildings and wharves adjoining.

The warships in the Yellow Sea opened fire on Iltis Fort, and for three hours we continually played our glasses on the field, on Tsingtau, and on the warships. With glasses on' the central redoubt of the Germans, we watched the effects of the Japanese fire until the boom of guns from the German Fort A, on a little peninsula jutting out from Kiaochow Bay, toward the east, attracted our attention there. We could see the big siege gun on this fort rise up over the bunker, aim at a warship in the sea, fire, and then quickly go down again. And then we would turn our eyes toward the warships in time to see a fountain of water, two 


\section{THE FALL OF TSINGTAU}

hundred yards from the vessel, where the shell had struck. We scanned the city of Tsingtau. The one hundred and fifty-ton crane on the greater harbor, which we had seen earlier in the day, and which was said to be the largest crane in the world, had disappeared and only its base remained standing. A Japanese shell had carried away the crane.

As the sun started to drop behind the Pearl Mountains in the west, our eyes were suddenly attracted by wavering flashes from fire close to Moltke Fort. Turning our glasses on the spot, we saw an armored car pushed by a locomotive suddenly dart out from the shadows of the fortress, run a short distance along the tracks of the Shantung railroad that skirt the Bay of Kiaochow, come to a stop, and then open fire upon the entrenched British force on its right. There were quick flashes of flames from its side as its guns poured round after round into the trenches, and then the engine would quickly pull the armored battery back behind the hill and from view.

But this first day's firing of the Japanese investing troops was mainly to test the range of 


\section{BEGINNING OF THE SIEGE}

the different batteries. The attempt also was made to silence the line of forts extending in the east from Iltis Hill, near the wireless and signal stations at the rear of Tsingtau, to the coast fort near the burning oil tank on the west. In this they were partly successful, two guns at Iltis Fort being silenced by the guns at sea.

On November 1, the second day of the bombardment, we again stationed ourselves on the peak of Prince Heinrich Berg. From the earliest hours of morning the Japanese and British forces had kept up a continuous fire on the German redoubts, in front of the Iltis, Moltke, and Bismarck forts, and when we arrived at our seat for the theater of war, it seemed as though the shells were dropping around the German trenches every minute. Particularly on the redoubt of Tai-tung-chen was the Japanese fire heavy, and by early afternoon, viewed through field-glasses, this German redoubt appeared to have an attack of smallpox, so pitted was it from the holes made by bursting Japanese shells. By nightfall many parts of the German redoubts had been destroyed, together with some machine guns. The result 


\section{THE FALL OF TSINGTAU}

was the advancement of the Japanese front line several hundred yards forward from the bottom of hills where they had rested earlier in the day.

It was not until the third day of the bombardment that those of us stationed on Prince Heinrich observed that our theater of war had a curtain, a real asbestos one that screened the fire in the drops directly ahead of us from our eyes. We had learned that the theater was equipped with pits, drops, a gallery for onlookers, exits, and an orchestra of booming cannon and rippling, roaring pom-poms, but that nature had provided it with a curtain that was something new to us.

We had reached the summit of the mountain about 11 A.M., just as some heavy clouds, evidently disturbed by the heavy bombardment during the previous night, were dropping down into Litsun valley and in front of Tsingtau. For three hours we sat on the peak shivering in a blast from the sea and all the while wondering just what was being enacted beyond the curtain. The firing had suddenly ceased, and with the filmy haze before our eyes we con- 


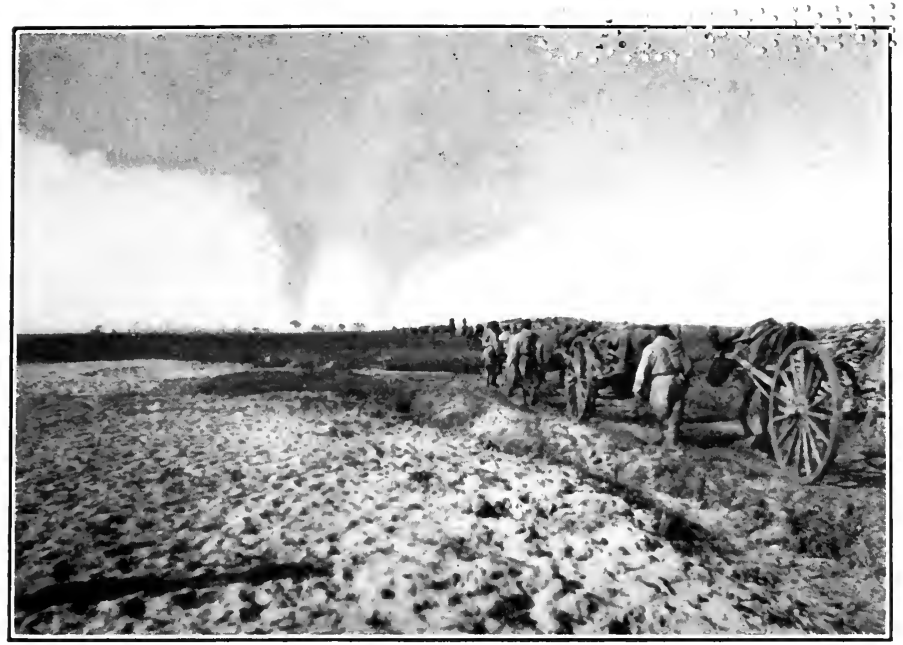

JAPANESE SUPPLY COLEMN ON THE WAY TO

THE REAR LINE

On the day of the opening of the siege, October 31. Two smoke-columns from the burning oil-tanks in Tsingtau can be seen in the distance

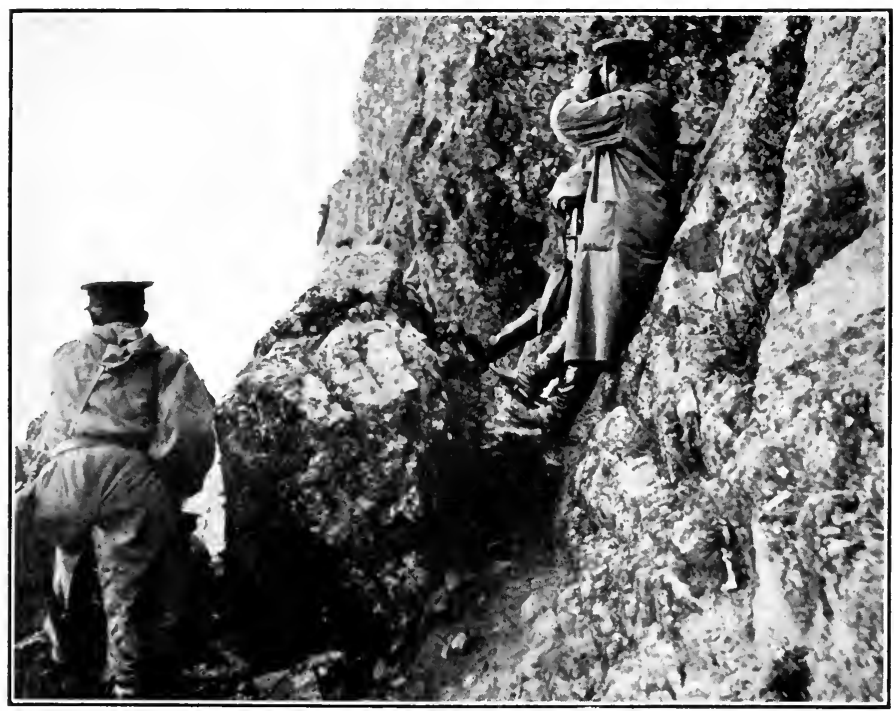

JAPANESE STAFF OFFICERS VIEWING THE

OPERATIONS OF THE SIEGE

On the top of Prince Heinrich Berg, a mountain 1000 feet high 
$\because$ 证,

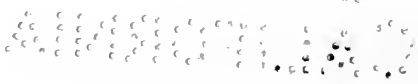




\section{BEGINNING OF THE SIEGE}

jectured pictures of the Japanese troops making the general attack upon Iltis Fort, evidently the key to Tsingtau, while the curtain of the theater of war was down.

By early afternoon the clouds lifted, however, and with glasses we were able to distinguish fresh sappings of the Japanese infantry nearer to the German redoubts. The Japanese battery, which the day before was stationed below us to the left, near the Meeker house, had advanced half a mile and was quartered just outside the village of Ta-Pau. Turning our glasses on Kiaochow Bay we discovered the Austrian cruiser Kaiserin Elisabeth missing, nor could a search of the shore line reveal it. We afterwards learned that the Germans had sunk the vessel in the Bay of Kiaochow early in the morning, after stripping it of all its useful war equipment. 



\section{BEGINNING OF THE SIEGE}

jectured pictures of the Japanese troops making the general attack upon Iltis Fort, evidently the key to Tsingtau, while the curtain of the theater of war was down.

By early afternoon the clouds lifted, however, and with glasses we were able to distinguish fresh sappings of the Japanese infantry nearer to the German redoubts. The Japanese battery, which the day before was stationed below us to the left, near the Meeker house, had advanced half a mile and was quartered just outside the village of Ta-Pau. Turning our glasses on Kiaochow Bay we discovered the Austrian cruiser Kaiserin Elisabeth missing, nor could a search of the shore line reveal it. We afterwards learned that the Germans had sunk the vessel in the Bay of Kiaochow early in the morning, after stripping it of all its useful war equipment. 


\section{CHAPTER VIII}

THE FLEET BOMBARDS THE CITY

The fourth day of fighting at Tsingtau was undoubtedly the most severe of the siege. With two guns on Iltis Fort already silenced, and with the Japanese force pressing the Germans hard in front of their redoubt walls, the Tsingtau garrison practically gave up the defense of their seacoast forts, and, with the exception of an occasional shot from Iltis, the battleships in the Yellow Sea were free to bombard Tsingtau at will.

Then it was that the Japanese, already famous for their military science, put into use, probably for the first time since naval warfare began, the wireless, as a means of marking the shots from the guns at sea. At the rear of the Japanese lines, a naval lookout had been erected, and there behind a bomb-proof shelter were entrenched several marines with horned telescopes focused on the Tsingtau forts. As soon as a shell landed, one of the marines 


\section{THE FLEET BOMBARDS THE CITY}

would telephone the exact location of the bursting shell to the wireless station near Lauschan and immediately the message would be relayed to the warships standing out at sea. In this way gunners on the Japanese and British warships knew, a moment after each shot, whether the great shells were finding their marks in the German forts. As a result few shells were wasted.

Well provided with maps, the gunners' officers could locate the spot where the shell dropped. If it was not a "hit," the big gun's aim would be changed, guided always by the wireless.

On land, the Japanese were regulating their gun-fire in somewhat the same way. An observation balloon was anchored each morning on the rear line, and with telephone connection running to every part of the field, the observers were able to make the gun-fire much more efficient. Slowly the German redoubts and casement walls commenced to crumple under the severe pounding they were receiving, and at the same time the zigzag lines of the Japanese saps were noticed to be continually nearing the German front defense line. 


\section{THE FALL OF TSINGTAU}

Over on the extreme right, near the Bay of Kiaochow, the gun-fire was extremely heavy. General Johoji, with General Barnardiston on his left, was pressing hard the entrenched Germans, in front of Moltke Fort. Early in the morning General Johoji had sent a detachment against the triangular pumping station fort, as it was deemed wise not to turn the siege guns on the place, because the fort might be destroyed and the supply of water be cut off in the city when the troops entered. The detachment approached the fort without any resistance from the Germans and surrounding it, discovered that there was a small garrison which had barred itself inside. The Japanese commanded the men to surrender, threatening to dynamite the place. The steel door was opened and twenty-three Germans walked out.

The capture of this fort was the key for the final attack of the Japanese, as it left the central fort and redoubts exposed to fire.

We had left Commanding-General Kamio early in the morning, after taking tea with him in his little dugout close to the base of Prince Heinrich Berg, and had started for the rear line, 


\section{THE FLEET BOMBARDS THE CITY}

there to watch the fire of the new twenty-eight centimeter siege guns that were just being put in position near the Litsun River. As we approached the line Japanese batteries in our rear would open up and we could hear a shell go tearing through the air with a noise like a giant skyrocket.

Through zigzag saps, ten feet deep, we crept along, now hugging the bank of the trench, with occasional stops, to make way for stretchers bearing the wounded from the front line. The wounded and the dead appeared the same, just a stretcher with its bearers, a large, heavy, blood-stained canvas, with, perhaps, an arm dangling or a heavy boot protruding.

We spent the whole day on the rear line, until a snowstorm, not unlike those of western Canada, drove us to the charcoal fire of the naval lookout, near by.

Here, with telescope, were entrenched several marines, all seeking to mark the fire of the vessels in the Yellow Sea.

Late in the afternoon the fire became extremely heavy. The Germans seemed to be making sharp resistance to the Japanese, lest 


\section{THE FALL OF TSINGTAU}

they advance within the quarter-mile zone of the redoubt walls. The Japanese infantry, however, were sapping away, and as dusk settled over the field we saw the bright flash of bursting shrapnel from the German forts. It was the first shrapnel sent out by the Germans during the siege.

Ten, twelve, fifteen, and sometimes even twenty shrapnel shells could be counted bursting at one time, all in a straight line, over the Japanese front line, and then the big German searchlights would flash about the field. They would fall on fifteen or twenty Japanese sappers on the top of their trenches placing sandbags, and then the flash would disappear. A lull for a minute and then pom-pom-pom-pompom! the machine guns along the redoubt walls would open up and for fifteen minutes would pour shot into the fresh trenches. It was woe to a man in such a fire who was wounded away from his trench. Exposed to all guns, Red Cross workers would be unable to get to him and he would be left to die the death of a soldier.

All night long the firing kept up, and for 82 


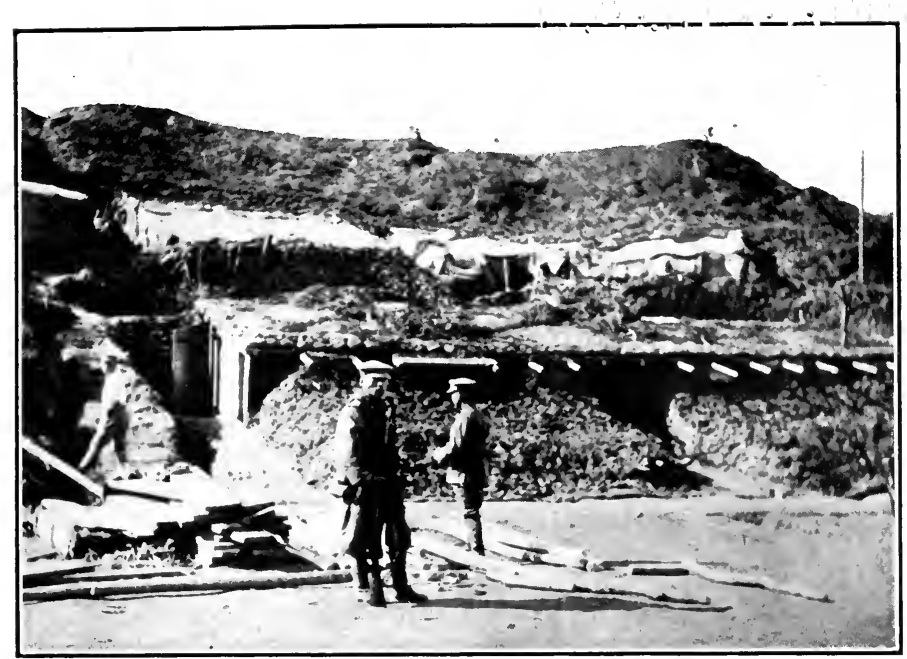

QUARTERS OF THE JAPANESE STAFF OFFICERS DURING THE CLOSING DAYS OF TIE SIEGE

Within a hundred yards of the rear line of the attacking force and the big 24centimeter siege guns. The large lean-to in the foreground was the home of General Kamio

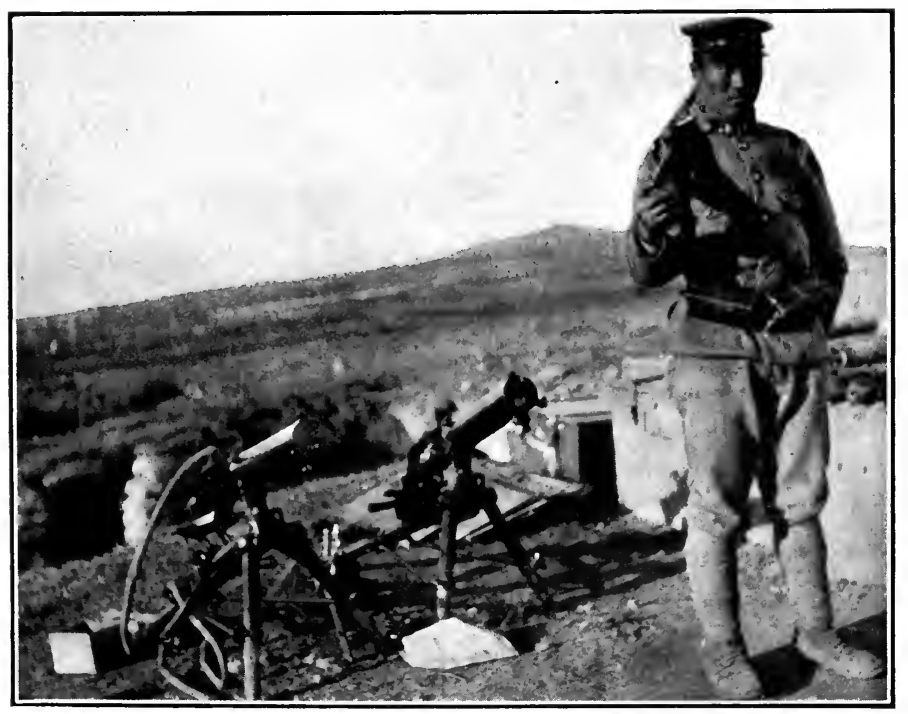

GERMAN MACHINE-GUNS ON THE REDOUBT WALLS

OF THE TSING'TAU FORTS

The pom-pom-pom of these guns and the shriek and whistle of shrapnel made a nightmare of the starlight hours during the closing days of the siege 


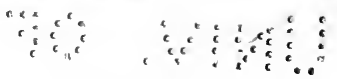

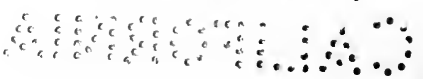




\section{THE FLEET BOMBARDS THE CITY}

miles into the hinterland the ground trembled and echoed from the discharging guns. Tsingtau was now in darkness, Japanese shells having disabled the electric power plant and the flash of the German searchlights from the forts was missing. Instead star-shells took their place, and bursting high in the heavens above the entrenched British and Japanese forces they flooded the country with daylight and gave a spectacular touch to the fighting.

Thursday, November 5 , seemed only a repetition of what had been witnessed the day before. The Tsingtau forts were a cloud of smoke and dust from the hundreds of shells that were falling upon their slopes.

I took tea with General Kamio in the morning, and he told me he would notify me ahead of time when he would order the final attack on the forts, so I could witness it. Night, of course, was to be used to screen the attack, and from what I gathered from the staff officers' remarks, it was to be a stubborn affair, with, perhaps, the loss of more than an entire regiment - eight hundred men.

"Oh, the Japanese are getting too impa- 


\section{THE FALL OF TSINGTAU}

tient," said Captain Shaw, back in the British Red Cross camp, a few hours later. "It will be a shame if they make that attack, for I am going to lose all my men if they do. And that's what hurts. I know all these men, I've worked with the most of them for years, and they are all good chaps. I hate to give them up."

In fact all the British officers at Tsingtau, when they heard that the Japanese staff officers were planning on an assault of the Tsingtau fortifications, were down in heart. The British preference was for slower and less costly methods than those insisted upon by the Japanese commander. The viewpoints of the two armies seemed to hinge on the judgment of the professional soldier, such as Great Britain's, and the soldier of conscription, as Japan's. But of the professional soldiers there were not and could not be enough. And being so few, General Barnardiston, as well as the other officers, were reluctant to sacrifice them. But the British general, being under the orders of General Kamio, the commander-in-chief of the investing forces, had to abide by the plans of the latter. Due to the lack of ammunition in Tsing- 


\section{THE FLEET BOMBARDS THE CITY}

tau, the assault, when it did take place two days later, did not prove so costly of life as was first expected.

Late in the afternoon the Japanese blockading fleet closed in on the southern end of the entrance to the Bay of Kiaochow and started a bombardment of the city of Tsingtau. At first the Tsingtau residents were unable to locate the source of the gun-fire as the ships were shielded in the sea by Cape Jaeschke. However, to the city itself it was the one exciting moment of the whole war.

With shells coming right into the city front and around the Prince Heinrich Hotel, which was being utilized as a hospital, there was a hasty retreat for cover farther into the city. Every one took to the basements and there spent the night, in deadly fear of the large shells which were crashing into building fronts every few minutes.

That night the Japanese forces advanced two hundred yards under a heavy shrapnel fire from the Germans. A snowstorm, followed by rain, had filled the trenches with water a foot deep, and it was in these that the Japanese and 


\section{THE FALL OF TSINGTAU}

British forces found themselves during the closing day of the siege. Friday, November 6, was a bitter morning. A forty-mile gale was blowing off the Yellow Sea, and with the thermometer at two below zero it was not any too comfortable even for those of us who were fortunate enough to get near a charcoal burner.

Out in the trenches stood the troops, in water over their shoetops, no overcoats, many without mittens, their hands on cold steel, without the warmth of a fire for the last three days, and only an extra ration of hot tea to keep them up.

All day the shrieks from the shells continued, but when I returned to General Kamio's quarters, every one was of the opinion there would be only one more day of this and then the night attack of the infantry. 


\section{CHAPTER IX}

THE SURRENDER

The fighting during the closing hours of November 6 found the little German garrison at Tsingtau pressed to their utmost resistance against the inevitable. For more than two months they had been at war with the small khaki-clad soldiers of the Nippon Empire, not with any hope of finally coming out victorious in the struggle, but simply to stave off the hour when they must lay down their guns and be humiliated by seeing the Rising Sun flag replace the banner of the Fatherland above the fortresses of the German protectorate. That hour had come.

But twenty-five yards from the front wall that skirted the Tsingtau fortresses for three miles from the Bay of Kiaochow on the right, to the Yellow Sea on the left, was entrenched the front line of the Japanese and British expeditionary forces. Behind this line of underground fighters was another line, a third, and 


\section{THE FALL OF TSINGTAU}

then the large, massive twenty-eight-centimeter siege guns of the Japanese, which at various intervals of the day had been hurling projectiles with a deafening roar, scattering death within the walls of the fortress as a reminder to its garrison members that Germany must leave Asia.

As I stood on the rear Japanese line that night, close to General Kamio's dugout, and gazed toward the German fortresses at Tsingtau, the scene before me appeared much like a spectacular pyrotechnic exhibition. Star-shells continually fired from the German walls would burst in the heavens above and for several minutes would continually keep lit the field below. Japanese infantrymen could be seen outside fresh trenches placing sandbags and the like, and with darkness covering the field again there would be a few seconds of deathly stillness and then the machine guns along the redoubt walls of the Tsingtau forts would open up. From all about the field in front there appeared the bright red flash of flames as field and siege guns went into action, and the echo of their deep roaring undertones would at 


\section{THE SURRENDER}

length subside into the ripping pom-pom-pom of the German machine guns as they attempted to check the advance of the Japanese sappers.

Toward midnight, the fire from the Tsingtau forts had slackened somewhat, - due, as afterwards learned, to the giving-out of ammunition supplies, - and noting this condition of affairs, General Yamada, whose men were entrenched in front of Forts 2 and 3, sent out a detachment to learn the condition of the garrison opposing him.

The men approached the redoubt walls of the forts, climbed down ten feet to the bottom, and found themselves facing wire entanglements, ten yards wide and running the length of the wall. No Germans were seen. Reinforcements were called for while the advance guard was cutting the entanglements, and by 1 A.M. on the morning of November 7, General Yamada with more than three hundred men was behind the central redoubt walls of the German forts.

In the mean time, heavily protected on all sides by planks and sandbags, a detachment of 


\section{THE FALL OF TSINGTAU}

two hundred Germans, with machine guns, was watching the approach of General Barnardiston's men, who had been stationed to the right of General Yamada. The Germans were unaware that the Japanese had gained the wall when suddenly a sentry heard Japanese voices in the inky blackness before him and the signal was given.

Rushing from their little sandbag fortress, the German detachment hurried in the shadow of the redoubt wall toward the casemate approaches, hoping, in so doing, to reach their comrades stationed five hundred yards back along the casemate walls. Some undoubtedly reached their destination, but the majority of the men were shot down by the Japanese as they ran toward the approaches unconscious that Japanese guards were there.

The capture of Forts 2 and 3 by General Yamada was quickly reported to General Horiuchi, and within an hour his men had captured Forts 4 and 5 with little resistance. General Johoji, on the extreme right, with the British expeditionary force to his left, under General Barnardiston, also advanced with the news of 


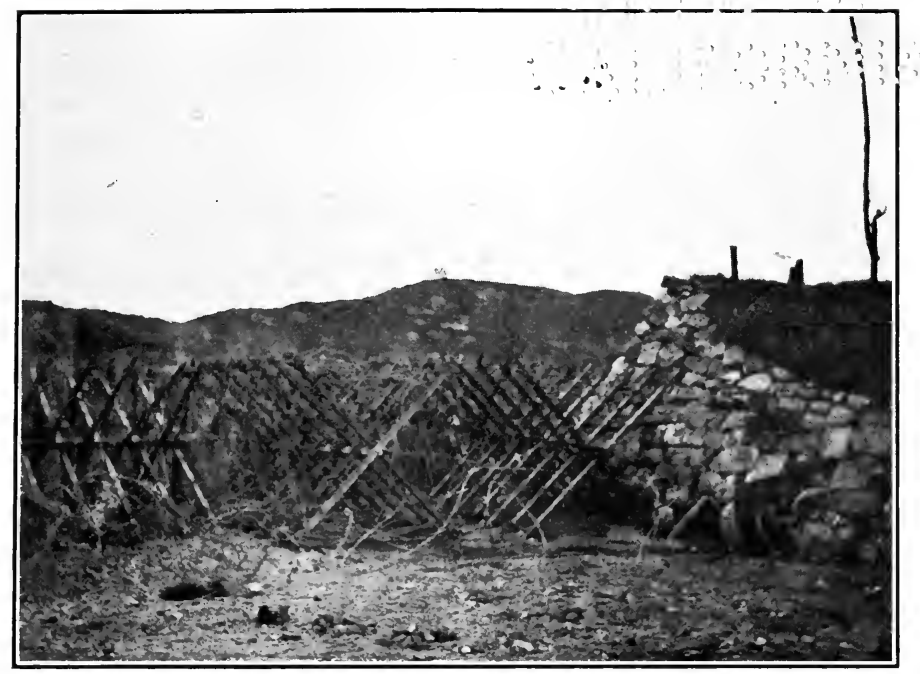

GERMAN BARBED-WIRE ENTANGLEMENTS

Along the redoubt walls of the Tsingtau forts

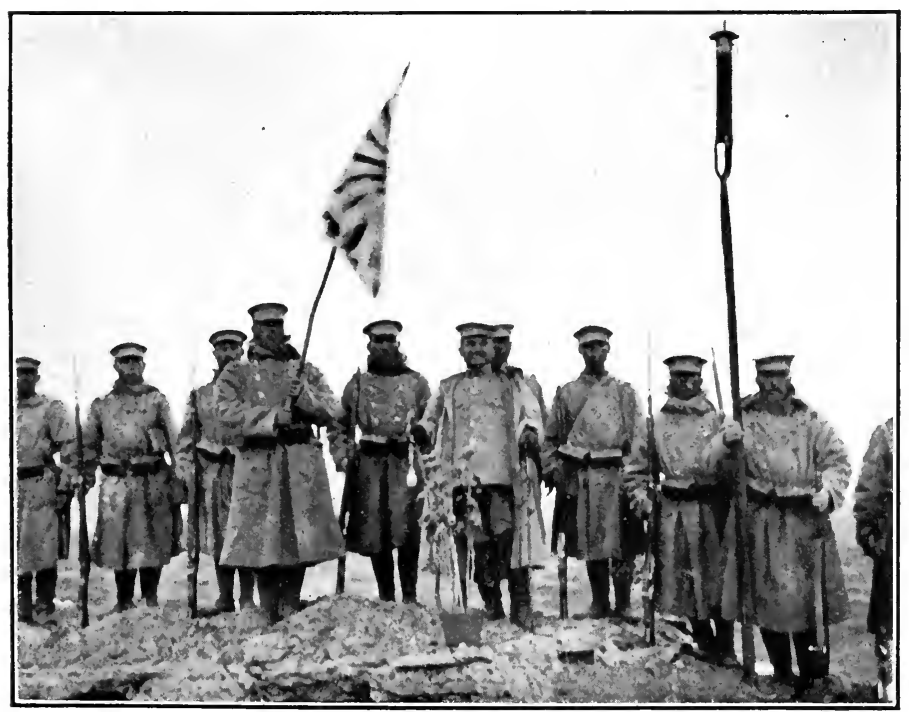

GENERAL HORICCHI ON THE CREST OF MOLTKE FORT

He stands smiling, with a chrysanthemum, the Japanese national emblem, in front of him. He and his men had captured this fort 



\section{THE SURRENDER}

the capture of the positions, but the Tsingtau garrison seemed to have concentrated its attack at this position and General Johoji's advance was met with stubborn resistance.

Utilizing the high-banked macadam roadway that runs from Litsun into Tsingtau as a cover, the British force was able to advance to the Tsingtau redoubt walls without suffering much damage, and, after tearing a hole through the stone guard, was able to capture the fort. The capture of Fort No. 1 by the British was closely followed by General Johoji's capture of the coast fort at 6.30 A.M.

The German front and second line of defense was now in full retreat toward the three mountain forts, Iltis, Bismarck, and Moltke, about a quarter of a mile in the rear of the captured redoubt and casemate fortifications. General Yamashita, chief of the Japanese staff, realizing now the weakened condition of the Germans, ordered General Yamada and General Horiuchi to advance with detachments of engineers and infantrymen and to begin the general attack.

After weeks in rain-filled trenches, the at- 


\section{THE FALL OF TSINGTAU}

tacking force was only too eager to begin the hand-to-hand encounter that would eventually mean the surrender of Tsingtau, and so with orders given, they rushed from their trenches over the redoubt walls and behind the advance Japanese guard started their charge up the steep slopes of the Tsingtau mountainous fortresses that rose one thousand feet high.

With bayonets in front of them gleaming in the glow of the morning sun, just rising as a ball of fire from above the horizon of the Yellow Sea, the attacking force charged up the slopes. Two guns on Iltis Fort had been silenced; the four big twenty-eight-centimeter mortars on the same fort were useless for work at the base of Iltis, while the other guns, making up the German equipment, had been so placed and sandbagged at the rear of the forts that they could not be quickly brought forward and utilized for work along the steep slopes leading to their summit. Rifles and machine guns were resorted to.

The Japanese, as they charged up the slopes, were mowed down by the machine guns, but on they came from all sides $-17,000$ men against 


\section{THE SURRENDER}

3800. The German garrison could not hold out and the white flag was seen suddenly to be hoisted from near the Governor-General Meyer-Waldeck's residence. The surrender came at 7.05 A.M.

As the white flag struck the top of its mast the air about the forts was suddenly rent by the "banzaiing" of the victorious troops. For twenty minutes the cheering kept up, until at length it was replaced by the appearance of the Rising Sun flag floating from the peak of every fort and hill in the neighborhood. Thus had Germany's dream of domain in the East come suddenly to an end. 


\section{CHAPTER $\mathrm{X}$}

\section{AFTER THE CITY'S FALL}

Scenes of havoc met the eyes of the Japanese staff officers when they entered the fallen forts of Tsingtau. With dynamite and nitroglycerine the German defenders had destroyed the guns and demolished all that might be taken by the captors as trophies of war. Along the casemate walls of the forts still lay the German and Japanese soldiers who had been killed in the final assault, while the concrete forts themselves were just a mass of shale and twisted steel rods where dynamite or falling shells had done their work.

Into the forts the Japanese filed and, collecting all the German soldiers together in lots, marched them to the barbed-wire entanglements in the rear of the city and after a short rest took them to the foot of Prince Heinrich Berg, where a prison camp had been improvised. The German officers, however, through 


\section{AFTER THE CITY'S FALL}

the courtesy of the Japanese commander, were allowed to remain in Tsingtau.

The courtesy of the Japanese, for which the Orient is already famous, received an excellent demonstration in the surrender of Tsingtau. General Kamio, commander-in-chief, realizing that to march his victorious troops through the city of Tsingtau would throw the residents into much confusion and disorder, made the direct surrender appear like a capitulation on terms. All German officers, including Governor-General Meyer-Waldeck, were allowed to go about Tsingtau at their freedom after the surrender, and General Kamio at once posted orders that only the Japanese staff officers would be allowed to enter the city for several days. Japanese pickets were placed along the roads outside of the city to see that this regulation was enforced.

For several days, then, while the Japanese troops were quartered in Moltke and Bismarck Barracks in the rear of Tsingtau, and the British force was also in German barracks, the residents of Tsingtau were given free opportunity to recover from their besieged life without 


\section{THE FALL OF TSINGTAU}

being ruffled by the sight of marching and quartered troops.

During that period between the surrender of the Tsingtau forts and November 16, when the British and Japanese expeditionary forces made their triumphal entry into the city, the Japanese officers busied themselves in the final preparations for the transfer of the German possessions into the hands of Dai Nippon. The rest of the troops spent the days in examining the Tsingtau forts and gradually the "whyfore" of their surrender was answered.

On Iltis Fort were mounted six twelve-centimeter guns, two of which had been captured from the French in the siege of Paris in 1871. On the left of this battery and toward the rear of the fort had been placed four twenty-eightcentimeter mortars, while two 10.5-centimeter guns cast in 1889, which had seen service in the siege of Taku in 1900, made up the remainder of the fort's equipment.

Bismarck Fort, to the left of Iltis, seemed to be the most strongly fortified of any of the Tsingtau defenses. Besides four twenty-eightcentimeter howitzers and two twenty-one-cen- 


\section{AFTER THE CITY'S FALL}

timeter guns, it contained the Tsingtau battery of four fifteen-centimeter guns.

At Moltke Fort, on the bay side of the city, the German garrison had mounted two fifteencentimeter guns stripped from the Austrian cruiser Kaiserin Elisabeth, a field battery of ten pieces, three field howitzers, and several small guns taken from the second-class German gunboats and cruisers that had been allowed to be bottled up in the Bay of Kiaochow.

The two German forts which commanded the sea approaches were Huit-chien-huk and Tscha-nui-va. The first was equipped with two twenty-four-centimeter guns and three fifteen-centimeter guns, while the latter's equipment consisted of two twenty-one-centimeter guns which had been taken from the Chinese Taku forts in 1900.

The German garrison at Tsingtau at the opening of the war, knowing that their surrender was inevitable, had made all plans to keep as far as possible all trophies of war from falling into the enemy's hands after surrender. The result was that early on the morning of the $7 \mathrm{th}$, after the Japanese infantry had gained the 


\section{THE FALL OF TSINGTAU}

redoubt walls, all preparations were made by the garrison for destroying the guns.

The breech-block of each was wound with nitroglycerine and dynamite was placed in the cannons up to the muzzle edge. The white flag was the signal. A few minutes later, when the Japanese forces swarmed the forts, they found the place a mass of wreckage. Big twenty-fourcentimeter guns were split in two as evenly and neatly as if they had been cut by a jack-knife, while one hundred or more yards distant could be found all that remained of the breechblock. The four twenty-eight-centimeter mortars on Iltis had been dynamited and just a mass of twisted steel and splintered plates remained.

On Bismarck and Moltke Forts, many of the guns had been backed in against the sandbag walls and dynamited on their carriages. The discharge had left the place scattered with the broken pieces of the carriages and split sandbags. The guns in the majority of cases had fallen down to the foot of the casemate walls. The explosions of the dynamite also appeared to have wrecked adjacent walls, for the con- 


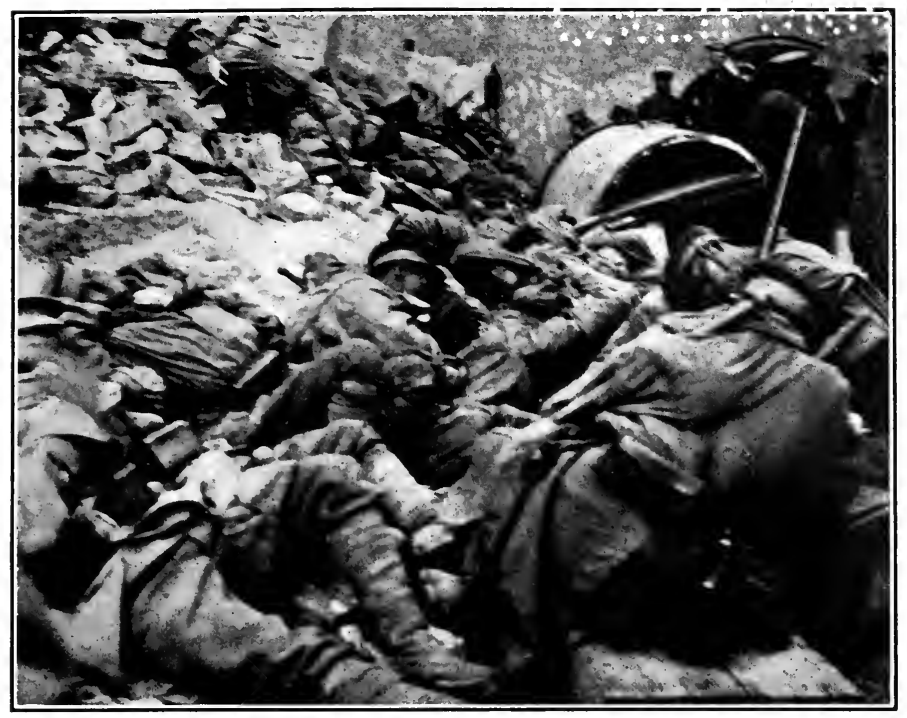

THE FOOT OF 'THE CASEMATE WALLS THIR'TY MINU'TES AFTER THE SURRENDER

Fatigued by their past thirty-six hours of work in storming the German forts, the attacking force lropped wherever the white flag found them, and there they slumbered while the soldiers of the German garrison (in the background) smiled upon their conquerors

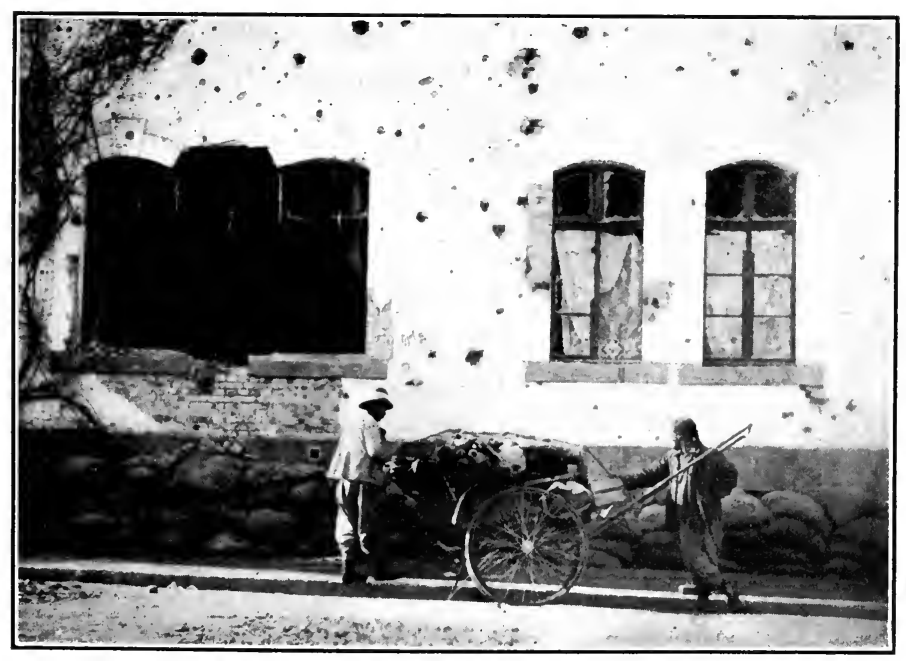

THE MOL'TKE BARRACKS AFTER THE SURRENDER

Showing the effects of Japanese shrapnel. Sandbags were placed about buildings in the eity to keep shells from undermining them 
等, 


\section{AFTER THE CITY'S FALL}

crete work about the gun-stands seemed to be so much shale. Exposed to sight were the steel pipes and wire used in the construction of the forts, all twisted and broken.

This desire to keep trophies of war from the hands of the enemy was not confined alone to guns. From the various post-offices German officials gathered the colony's issue of postage stamps and all were burned. Men had evidently been detailed to handle the storehouses, for all about them I found large cans of corned beef, sausages, milk, saurkraut and German delicacies opened and lying in heaps, their contents untouched.

All valuable papers in the vaults of Government buildings that contained military secrets or maps of fortifications throughout the Far East, were also made way with; in fact the German garrison left little that the Japanese could boast about, except the city of Tsingtau itself.

As officially given out by the War Office, the Japanese forces had a total of 142 guns on the firing line. They consisted of 6 28-centimeter howitzers, 72 other siege guns of 15- and 24- 


\section{THE FALL OF TSINGTAU}

centimeters, 18 mountain guns, 36 field pieces, and 84.7 and 6 -inch guns of the marine detachment.

According to figures given me by General Kamio, the total active fighting force of the Japanese during the siege was 20,000 men, while the British expedition force consisted of 925 regulars, with a regiment of 300 Sikhs.

Opposing them was the German force of 4500 men, more than 700 of whom were sick or wounded or captured before the actual siege started.

Among the criticisms directed against the defenders of Tsingtau, which I heard after the surrender, especially in the British camp, was that the Germans fired away great quantities of ammunition at the beginning of the bombardment of the fortifications so that, with their supply exhausted, an excuse for the surrender could be made. In proof of this they referred to the large number of shells which fell daily about the Japanese forces while they were getting the big siege guns into position. The estimate of "more than two thousand German shells in twelve hours' firing with no casu- 


\section{AFTER THE CITY'S PAIL}

alties to the Japanese or British forces," was further evidence given.

On my first trip into Tsingtau I met a German officer in the Prince Heinrich Hotel, who had taken part in the siege, and questioned him as to the truth of the statement.

"Maybe that is what they say, but the facts are the garrison had expected Tsingtau to fall sooner than it did. Our heavy artillery fire was not kept up for the purpose of throwing away our shells, - it would have been less dangerous to have dropped them in the bay, - but solely to do as much damage to the Japanese as possible before the assault on the fortifications could be made. We regulated our fire with the one purpose of covering the country with shells before they had a chance to get under cover. When they attempted to mount their siege guns at the start of the bombardment their forces were exposed to us. We could see their ammunition columns and supply wagons rolling up on open roads and, by spreading our fire about the valley, we were attempting solely to postpone the fall of Tsingtau as much as possible by hindering the allied forces in their work." 


\section{THE FALL OF TSINGTAU}

The officer then went on to tell me of the ruse Lieutenant Trendel, manager of the Wagonlits Hotel at Peking, who took part in the siege, played on the Japanese. Trendel was in command of a battery of six old ninecentimeter ships' guns which were in an exposed position on a ridge near Iltis Fort. This battery received a fire from both the ship and land guns, and the men could be seen on the first day of the bombardment building bombproofs in the dust and smoke from exploding shells.

In the night Lieutenant Trendel put up wooden guns, roughly shaped from beams, at a distance of two hundred yards from his own guns. In the morning, he exploded powder near them to give an appearance of firing from them. By his ruse he diverted the Japanese fire and saved all his men, dynamiting his guns before the surrender.

Governor-General Waldeck, after the surrender, made the following statement as to the bombardment: -

The combatant force at Tsingtau did not amount to more than forty-five hundred. The permanent 


\section{AFTER THE CITY'S FALL}

garrison consisted of eighteen hundred men nominally, but was, in reality, about two hundred short. Some of those under arms were mere boys. Each fort was defended by about two hundred men.

The Tsingtau guns were mostly weapons captured from the Boxers during their rebellion, or trophies of the Franco-German War, and were no match for modern arms. The Huichuan and Bismarck Forts, however, had some modern pieces. Altogether there were, for the defense, about sixty guns and a hundred machine guns.

The Iltis fort was guarded by sixty men. The Japanese in their assault charged up under a hot fire as if unconscious of their danger, and gained the position before the defenders could call reinforcements.

The Bismarck and Moltke Forts were also taken by a charge, but for the most part the Japanese conducted their attack under cover of their trenches, and concealed themselves so well that the most searching German fire could not stop their advance. At length the supply of ammunition ran out, and further defense was futile. I thought the Japanese casualties would be very heavy, as they fought bravely and charged desperately, and I estimated their loss at five to six thousand. I have been astonished to learn that the loss in killed and wounded amounts to only seventeen hundred. They certainly showed remarkable skill in taking cover.

Tsingtau was not an ideal fortification, such as Antwerp. Strictly speaking, it was merely a defended position. As possible enemies in the Far 


\section{THE FALL OF TSINGTAU}

East, Germany had calculated only on England, France, and Russia. It was quite unexpected that the blow would come from so good a friend as Japan.

The fire from the Japanese squadron was not so furious as to cause any great inconvenience, except once when a shell landed in the Huichan Point Fort, killed thirteen and severely wounded three. In respect of accuracy of range the fire of the British cruiser Triumph was inferior to that of Japanese ships. The land fire, however, was terrible. A perfect rain of shells fell on the Bismarck, Iltis, and Hsiaochau Forts, and the central batteries suffered severely. One of them received as many as a hundred shells, and it was death to leave the trenches for an instant.

Two days after the surrender I was able to get through the picket line thrown about the rear of the city of Tsingtau, and could observe better just what damage had been done to the city during the seven days of bombardment.

The city appeared as if a typhoon had passed through it. Its wide asphalt and macadamized streets, fronted by beautiful four and five story buildings of German architecture, were vacant. Giant shells, some three feet long and a foot in diameter, were lying about on sidewalk and street still unexploded. Trees, splin- 


\section{AFTER THE CITY'S FALL}

tered at their bases, lay toppled over in the avenues. Windows in the houses were shattered, while gaunt holes in the sides of buildings, where shells had torn their way, made the residence blocks appear to be gasping for air.

Out in the harbor could be seen the spars of the Rickmers and two or three other German freighters, which had been sunk at the opening of hostilities about the city; while farther out in the channel was the grave of the Austrian cruiser, Kaiserin Elisabeth, which had been sunk by the Germans.

The whole scene seemed one of devastation. Streets deserted of people, show-fronts of stores completely gone, as was also the merchandise, harbors deserted of ships, and not even a sign of a ricksha to remind you of the Orient.

Such was Tsingtau as I first saw it two days after its surrender. But for the continual sight of the Rising Sun flag flapping from every peak in the rear of the city, as well as from every Government building, and its message of "occupied," one would have thought Tsingtau a city deserted. 


\section{CHAPTER XI}

\section{TAKING POSSESSION}

THE transfer of Tsingtau to the allied forces was commenced on November 11, and, two days later, the majority of the German officers who were not needed by the Japanese in spotting the land mines were marched off to Sesheco to be transported to Japan. During the final transfer I lingered about the field below Moltke Barracks, on which had gathered about one thousand German prisoners of war, with their officers. As Governor-General Waldeck and his officers were going through roll-call, the scuff-scuff-scuff sound of marching troops was heard along the roadway near by leading over a small slope. The sound of the heavy boots hitting the ground was shortly followed by the whistling of many men, and all the heads in the field below quickly turned toward the crest of the hill, where the road disappeared.

In a few minutes they appeared in sight first four bayonets, four khaki-colored helmets, 


\section{TAKING POSSESSION}

then four men, another four men - nine hundred strong, the British expeditionary force, marching to the German barracks, whistling "Everybody's Doing It."

At the sight the heads in the field below immediately turned toward Governor-General Waldeck, while the faces of neutrals on the side lines turned into smiles. That tune whistled by the Britishers evidently grated on the field below, and a few minutes later, when an officer shouted in German for the men to form on the roadway, one thousand voices burst into a German war song.

I stood by the roadway as they formed; some with heavy packs strapped to their backs, others carrying accordions, mandolins, and guitars in their hands. As they marched by me, all stared.

"English or American?" some would ask.

With the nod of my head to the latter they seemed to rest content and would pass the remark on to the other, "newspaperman."

Five days later, the formal entry of the allied forces took place at Tsingtau. Following the review of the forces by General Kamio and 


\section{THE FALL OF TSINGTAU}

his staff, the troops marched to the Strand on the Yellow Sea, where a wooden monument, much like Cleopatra's Needle, stood banked in the center of the sands. Large straw-wrapped casks of sake, or Japanese wine, stood on each side of the monument, a gift to the departed souls of the Japanese dead, from their Emperor and Empress. Heaped on top of the casks were thousands of cigarettes, bowls of rice, chrysanthemums, the national flower of the Empire, and many eatables much prized by the Japanese.

After all the troops had assembled facing the monument, General Kamio approached it with a large scroll in his hand. All helmets and caps of the troops in front of him went off. He stepped on to the path leading directly to the monument, took off his cap, bowed, and then approached. Stopping within a foot of the monument, General Kamio bowed again, and then slowly opened the scroll. Not a sound could be heard in that gathering of thousands in front of the monument, except an occasional neigh of a cavalry horse.

The scroll opened, he read from it in Japanese the following message to the dead:- 


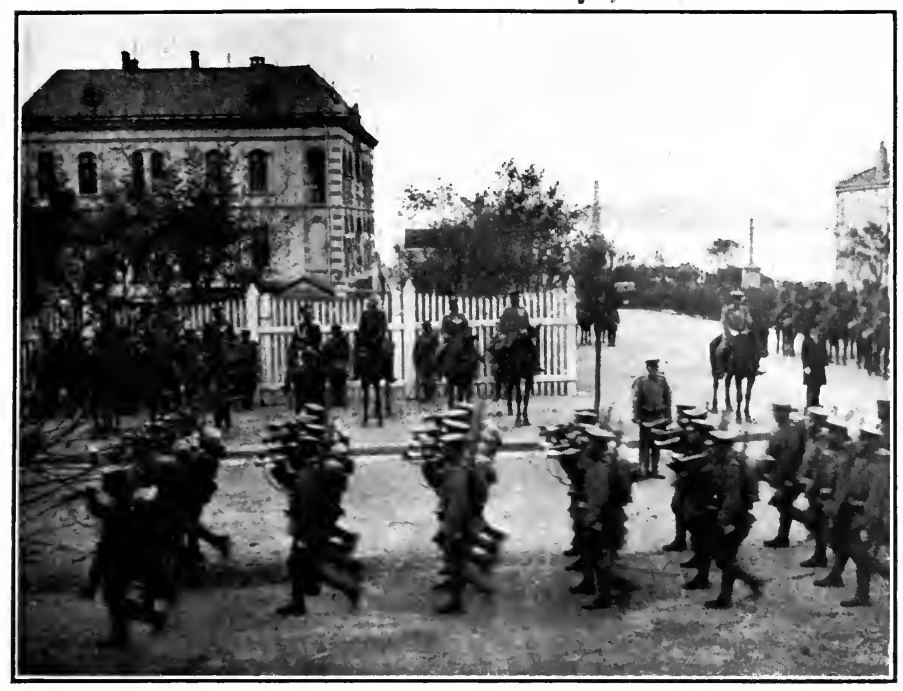

TRIUNPHAL ENTRY OF THE JAPANESE TROOPS INTO TSINGTAU

The military attachés of the United States, Greece, Spain, and France on the left, in front of the Asiatic-Deutsch bank

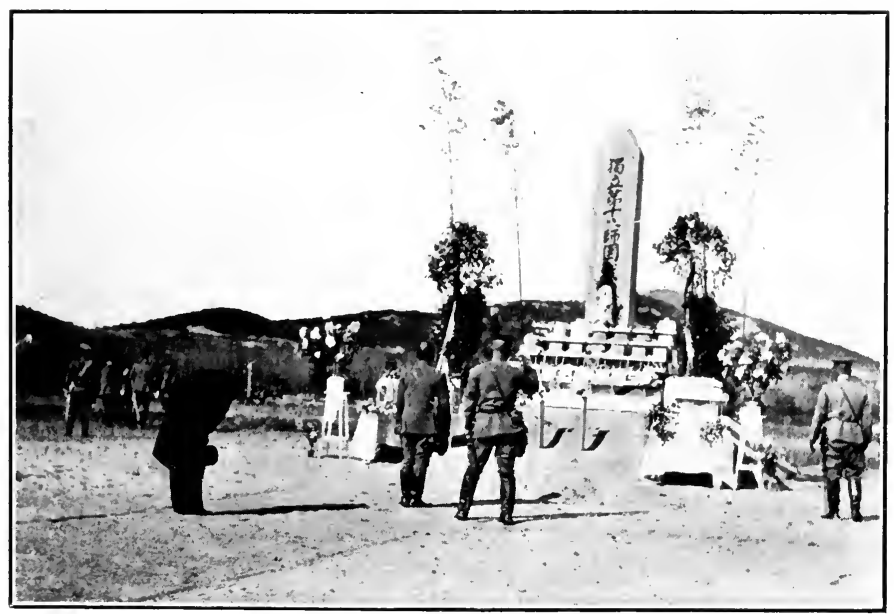

PAYING RESPECT TO THE SOULS OF THE JAPANESE DEAD

Before the monument erected on the shores of the Yellow Sea at Tsingtau 
$\cos$,

¿cis i jercici

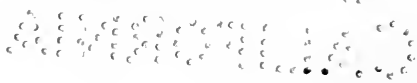




\section{TAKING POSSESSION}

I, the humble General Kamio, commander-inchief of the Japanese forces, express my hearty condolences to the souls of the dead who have been killed in battle or who have passed away from illness contracted during our days of war.

My Imperial Majesty's reason for declaring war against Germany was because Germany had expanded her war politics to the Far East. They occupied Tsingtau, and forced our neighboring Government, China, to give it up, thus destroying the peace of the Far East. Our Imperial Majesty was therefore called upon to drive the disturbing element from our hitherto peaceful shores.

I, the humble General Kamio, was appointed to be commander-in-chief of the allied army in its operation against Tsingtau. I and my staff, from early morning until late at night, have labored hard to achieve the desire of our Imperial Majesty and now Tsingtau is occupied by the allied army.

Its surrender is the result of the grace of heaven, the virtues of our Emperor and Empress, and the bravery of those passed souls which we honor today. We are assembled here to comfort you, $\mathbf{O}$ souls, and I ask that you receive the condolences which I, representing the surviving army, give to you to-day.

The rites were those of Shintoism and, as believed, the souls of the men killed and buried during the war, all gathered at this monument. As General Kamio finished reading from the scroll, an aide stepped up and handed him a 


\section{THE FALL OF TSINGTAU}

pine branch - the Japanese symbol for long life - and the commander-in-chief placed it upon the monument, bowed, and stepped down along the path that faced the troops. The impressive ceremony was over.

The troops then returned to their quarters, while the officers of the Japanese and British forces were entertained at a banquet in Bismarck Barracks.

Tsingtau had now formally passed into the hands of Japan, and but two weeks later the British expeditionary force returned to Hongkong on the Triumph, and later embarked again for the war in Europe. The Triumph proceeded to the Suez Canal, afterwards distinguishing herself in the siege of the Dardanelles, but was sunk later by the enemy's torpedo. 


\section{CHAPTER XII}

\section{SANITATION AND DISCIPLINE}

As to the military organization of the Japanese, I think the operations of their troops in Shantung will add little to their reputation for scientific work. Surely on one point - that of sanitation - the military attachés of Holland, Spain, France, Greece, and the United States, who were present with the Japanese army during their war operations, if they can speak, will bear me out on the point that sanitation was something wholly lacking in the Japanese warcamps.

Military experts will tell you that in a campaign when the troops move camp, ditches should be dug almost before tents are pitched. The Japanese war-camps I found the exception. to this rule. Even in the question of "mess refuse," I found upon inspection that the Japanese provided no ditches. Rivers and creeks, already typhoidal, were principally used as the dumping-grounds of camp refuse, and days 


\section{THE FALL OF TSINGTAU}

after the camps had passed, the bivouacking spot would stand out as a stain upon nature: tin cans and rubbish all about, with old meat, and rice, paper, and other refuse cluttering.

Even during my days with the Japanese army in the model German barracks of Moltke Fort, I found this same Japanese lack of sanitation. Unprintable, is the way to describe the conditions resulting from the complaisance of the Japanese officers in permitting the soldier inmates to litter doorsteps and hallways with refuse.

But this disorder of Japanese camps, not only applied to sanitation, but as well to the handling of their troops after the surrender.

With the recent history of Japan showing that the little island nation goes to war at intervals of every ten years, and with its large army of conscription not knowing what defeat is, they are continuously kept under the intoxication of victory, with the result that carelessness is bred among them.

With the surrender of Tsingtau the Japanese generals appeared to have lost control over their men. "There was quite a little looting 


\section{SANITATION AND DISCIPLINE}

going on by the Japanese yesterday," said a British captain to me the day after the surrender; but for the next several days when I visited the city I found that the statement applied to more than "yesterday." Wherever I went I was met by faces of Japanese soldiers peering from deserted German residences. Upon a further inspection I found them searching through bureau drawers and going out of back doors with articles of various sorts.

Not for an instant do I think the officers of the Japanese army allow their troops to loot, for I think the Japanese Empire passed that stage of affairs after the relief of Peking, during the Boxer Rebellion. But what I saw taking place in Tsingtau after the surrender only bears out the statement that the Japanese army is becoming careless.

I do not think the Tokyo Government can dispute the point, when it accounts for the many deaths that occurred to its soldiers during the week after the surrender, from exploding land mines and the like. With practically every one in the war zone after the surrender. knowing the vicinities of the dangerous mined 


\section{THE FALL OF TSINGTAU}

ground, and with German officers right on the spot with maps showing the exact location of each mine, there seems very little excuse for such accidents, except as control of the army is lax and men are allowed to roam around at will.

On November 8, I heard a rumor in Tsingtau that forty Japanese soldiers and one officer had been killed in an explosion of a land mine near Moltke Fort. When I questioned Japanese officers regarding the matter, none denied that my version of the accident was correct. When I returned to Tokyo after the war I looked up the newspaper accounts to see if the War Office had given out anything on the matter, and in the "Japan Advertiser "I found the following: - "The following report was officially given out by the War Office: Ten men and an officer were killed in an accident at Tsingtau to-day."

To be sure, it was an accident that killed the men, whether eleven or forty-one, but will the War Office deny that the men met their death through carelessness? There were several other such accidents at Tsingtau to the Japanese 


\section{SANITATION AND DISCIPLINE}

army, but there were no casualties reported in the British camp after the surrender, and no one could find a British soldier away from his barracks unless on picket duty along the nearby roads. Days afterwards there was that same discipline about the British barracks. 


\section{CHAPTER XIII}

\section{OBSERVATIONS}

To an Occidental, themost conspicuous thing in the surrender of Tsingtau was the total absence of the British flag during the change of government. Though British soldiers were shoulder to shoulder with the Japanese in the trenches, and even though Japanese statesmen maintained that Great Britain had invited them into the war, this great opportunity in China, offered to Japan, appeared to require no credit to Great Britain or to the British flag.

With the exception of the British Red Cross camps in Kiaochow, and the British cruiser Triumph, the sight of the Cross of St. George was totally lacking from the Far Eastern phase of the European war. Great Britain had been silenced by her obligations to her ally. General Barnardiston, leader of the British expeditionary force into Kiaochow, maintained separate staff headquarters from that of the Japa- 


\section{OBSERVATIONS}

nese commander, but always he was under the orders of General Kamio.

The siege of Tsingtau marked the first time in the history of warfare that an army from a nation of the white race had united with and under the leadership of a nation of the yellow race. While Great Britain appears now from various quarters to have suffered somewhat in placing her leadership in the hands of Japan, the future portends similar bonds between Japan and other nations. Recently even Governor-General Meyer-Waldeck has expressed his approval of a German alliance with Japan, while Petrograd has been clamoring for several months for a similar alliance.

Undoubtedly the courtesy and humanitarian spirit displayed to the enemy by the Japanese during their war operations in Kiaochow have won the hearts of every German. While her traders feel keenly the loss of Kiaochow, there is not that bitter feeling displayed between the two nations, such as Great Britain and Germany have felt in the past, and no doubt will continue to hold toward each other in the future. German residents in Japan throughout 


\section{THE FALL OF TSINGTAU}

the war were allowed to continue in business and were given free access to everything without hindrance and with only the usual suspicion that confronts every foreigner in Japan. This was the spirit of Japan in the siege of Tsingtau.

In fact from an Oriental standpoint the siege of Tsingtau will always stand out as remarkably free from hatred. During the operations, Japanese officers sent many messages into the Tsingtau garrison, wishing their German friends and former tutors luck and safety during the siege. The Japanese officers seemed always courteous. They placed courtesy foremost, instead of indulging in recrimination such as usually goes on between the Germans and British officers and troops. General Kamio and his officers did not desire to humiliate the defeated German officers. The messages that were interchanged during the siege and afterwards were couched in the most courteous language, nor did Governor-General Waldeck and his staff officers lose their swords after the final surrender.

At Kurume, and the other little hamlets in 118 


\section{OBSERVATIONS}

Japan, where the German prisoners were quartered after the war, every convenience and facility and practical freedom for prisoners were given the men by the Japanese. Their favorite brand of cigarettes, their magazines and newspapers, - anything they wanted was theirs for the asking. During day hours they were allowed to roam around town streets for exercise, go on shopping tours and the like, and only when some German soldiers took advantage of the freedom given them by the Japanese by escaping, did the Nippon Empire put a more stringent watch upon the prisoners.

But the feeling between the Germans and the British after the surrender of Tsingtau - I could not help noticing it, for always I was taken for a British subject when around the German camps. The morning of the surrender, as I rode into the Tsingtau forts, German soldiers stood along the casemate walls hooting and hissing me. Stones were thrown at my horse and vile epithets hurled at me, and one German soldier especially seemed goaded by my presence. Taking off his hat he shouted at me in a bawling voice: "Three cheers for 


\section{THE FALL OF TSINGTAU}

Transvaal. Yes, and here is one of the Boers who was there."

And then one German, in a mimicking English brogue, shouted to some passing British troops, "Well, chaps, where will we see you in London?"

"Standing outside your cell in the Tower of London," proudly retorted one of the Britishers.

Always was it this pin-pricking of each other, this antagonizing, and only the presence of Japanese officers among the British group seemed to check the desire of the German and British soldiers to get at one another's throats.

And even into the one or two German provision stores at Tsingtau that were open after the surrender was the feeling of hatred between British and German carried. At the Sietas Plambeck store I found British and Japanese soldiers one day making purchases of various sorts. One British soldier was cursing in an undertone at the price of one yen he had paid for a can of pears, while a Japanese soldier was just receiving the same goods for half the price. 


\section{OBSERVATIONS}

In Japan's treatment of Germany and her subjects both England and Germany had in the siege of Tsingtau a fine object lesson of the excellent spirit of their Japanese brother. 


\section{CHAPTER XIV}

JAPAN AND AMERICA: PEACE OR WAR ?

Practically every discussion of the relations between Japan and the United States is based on a wrong assumption. It is assumed that the only points at issue between the two countries are involved in the California land law and the immigration question.

If these were satisfactorily settled, we are told by some, all friction would disappear and the two countries, in their amicable relations, might set a good example to a warring world. If they are not settled, we are told with equal insistence, the United States may expect war with Japan.

Unfortunately our relations with Japan are not so simple. Japan's destinies are not bound up in the California question. She may be humiliated, but cannot be harmed by all the laws the legislators of California or any other State put on the statute books.

On the other hand, the domination of the 


\section{JAPAN AND AMERICA}

Pacific and of China are projects toward which her statesmen have long worked, and toward which they have made progress.

The United States, with strong bases in the Pacific, and with a long record of sincere friendship for China, stands in the way of Japan's ambitions. With Germany eliminated from the Pacific, with Russia ready and eager for a partition of China, with England silenced by her obligations to her Japanese ally, Japan might at once become the autocrat of the $\mathrm{Pa}$ cific and the dominant power in China, were it not for the United States.

This is the real issue between the two countries. If there is ever a war between the two countries, and that appears doubtful, it will be because of Japan's ambitions, though legislation such as the California land law may serve as a useful pretext.

But this talk of the so-called "yellow peril," following the passage of the California land law, which first started the agitation in the United States of war with Japan, reminds one of the witchcraft scare in the New England States in the pioneer days of America. I be- 


\section{THE FALL OF TSINGTAU}

lieve that the danger of war with Japan lies more in the bark of the agitators than in the question itself.

We have seen placed on the statute books of Canada and Australia legislation which, as a barrier to the Japanese, is far more stringent than any acts passed by our Pacific Coast States. But has the reader heard any dangerous controversy arising between Japanese and British diplomats over the subject, or has there been any talk of Great Britain and Japan going to war because of such legislation?

No; because Great Britain has recognized Japan by its Anglo-Japanese Alliance. It is recognition from the Powers that Japan primarily wants - not emigration. The Japanese Government knows that the "all in all" question of its future is not bound up in the emigration of its citizens to the United States, there to take up their life residence, to rear their families and to become American citizens. But it does know that in the heterogeneous condition of the Far East it must solidify its colonies if it does not intend to see them rise in revolt and break away from the present Gov- 


\section{JAPAN AND AMERICA}

ernment. Emigration to America, Canada, or Australia will not bring about this desired condition for the Japanese Government, but emigration into her own colonies will.

Until twenty years ago the Japanese Empire consisted of one people and peace reigned supreme. Since then the Empire has acquired Formosa, Manchuria, the Liao-tung Peninsula, and Korea, and with the additional territory has come much turmoil in the colonial possessions from the contact of the Japanese with the natives. It has been a difficult question for the Japanese Government to solve, how best to link its added territory to the main empire; and the only practical solution of the matter has been emigration, sending its citizens from the main islands into Formosa and Korea, there to establish themselves in business and intermarry with the natives. In this way the foreigners would amalgamate in time with the Japanese.

But when it came to the emigration of its citizens, there was always the United States offering more opportunity than the Japanese Government could offer, and the natural trend was toward America. 


\section{THE FALL OF TSINGTAU}

Since the first outbreak of the California question, the Japanese Government has realized its mistake, and is now bending all efforts to make its possessions in China and about the Yellow Sea attractive enough to draw citizens of Japan into Japanese possessions rather than to America.

At present the Government has been meeting with much opposition in its immigration plans, for the Koreans as well as the natives of Formosa have a bitter hatred for the Japanese and trouble is met with once the peoples intermingle. With China still much of an enigma, and with its dissolution as a nation seemingly close at hand, much depends upon Japan's ability to solve her emigration question if she wishes successfully to accomplish her continental expansion in Asia and in the Pacific.

But during the present century, while Japanese emigration has been going on, and the Japanese war scare has been making the rounds of America, Japan has advanced, from being regarded by Europe as on the same level with China, to being a first-class Power, allied 


\section{JAPAN AND AMERICA}

with Great Britain, and consulted by all nations in matters affecting the Far East.

To the Japanese the California land law appears to be a refusal to recognize them as a first-class nation, because our Government has provided nothing to offset that opinion. Great Britain, however, while she, too, has been enacting California legislation in her colonies against the Japanese, has shown that she harbors nothing against them as a nation by signing the Anglo-Japanese Alliance.

Every foreigner who resides in Japan soon comes to learn that the Japanese are supersensitive. Failure to show little courtesies, which the foreigner would pass by with hardly a notice, strikes deep into the heart of the Oriental. For example, on September 8, 1914, in Yokohama, a Japanese killed his friend while passing him in front of the Yokohama Law Court, simply because the latter did not salute him with "ohayo" (good-morning). The accused man was perfectly sober at the time of his act, but his sensitiveness would not permit his passing by his friend's lack of courtesy without some notice of the fact. 


\section{THE FALL OF TSINGTAU}

And so it is with America's Japanese problem. We have struck deep into the heart of the Japanese by seemingly refusing to recognize them. They will remember the action, which to them appears as an insult, until America not Japan - does something to wash out the ill-feeling naturally resulting.

"I come now to the last important point demanding attention," writes Count Okuma, aged Japanese statesman, in his recent book, "Fifty Years of New Japan." "I mean our aspiration to be recognized by the world as a great nation. There is nothing strange in the demand that our people should be accorded the treatment due to their greatness as a Power, not merely in the Orient, but in the whole world."

With reference to the California question he says: "I am well aware that behind this antiJapanese sentiment there exist various circumstances which deserve consideration. However, in so far as our people are disliked because they are Asiatics, there is nothing reasonable or logical in their hostile feeling. To reason against and to remove these prejudices and misconcep- 


\section{JAPAN AND AMERICA}

tions is a mutual duty devolving as much on our people as on the Western nations concerned."

It is probably true that there are many Americans who dislike the Japanese because they are Asiatics, but these are in the minority; their bark carries with it no bite. On the other hand, the broad-minded men of both Japan and the United States realize that, underlying the California legislation against the Japanese, there are conditions which are proper for California to take note of. The work has been poorly done.

The average American and Japanese public have a misconception of the California legislation. It has a larger significance than just the question of admitting the Japanese. If the United States should admit the Japanese to immigration to this country, what point could you bring out in the Japanese as possible citizens that you could not find in the Chinese or in the Hindu?

In fact, the California action is not aimed directly at the Japanese, though the latter may believe the opposite and feel the sting of it 


\section{THE FALL OF TSINGTAU}

more sharply because their name is carried in the acts of legislation. No, the action is an indirect barrier to the immigration of any Asiatics to America. True it is, there is already a federal regulation against the immigration of the Chinese into this country, but it is mainly because of economic reasons, as is also the bar against the Japanese. Nevertheless, a great friendship exists between the United States and China, the same as there should exist between Japan and this country, and will exist as soon as America recognizes Japan satisfactorily as a Power.

The wholesale immigration of the Japanese into this country, however, would not bring this condition about. With the Japanese, as Count Okuma points out in his book, "unmorally developed" in business and in other ways, the immigration of the Japanese into this country would only result in the country being thrown into an economic disorder which in all probability would bring out serious trouble between the two nations.

Since Japan's stimulation of emigration to her own colonies of late, the Japanese war scare 


\section{JAPAN AND AMERICA}

in America has been gradually subsiding, but jingo press artists from time to time continue to heap coal on the dying fire by spreading broadcast the untruthful report that the Japanese are landing troops on the shores of Turtle Bay in Southern California or in some other section of the Americas.

In speaking of the improved situation existing between the United States and Japan, Count Okuma said in April, this year:-

Practically all of the friction that has arisen in America has grown out of one phase or another of the immigration question. That situation is improving somewhat and is one that I hope time will solve satisfactorily to both countries. It is a question which from its nature requires time for solution.

The United States has had other such questions with other nations, which have always been solved by time, and so I hope for a similar solution of this question. There are now about eighty thousand Japanese in the United States - that is, in the mainland territory - and as many, or perhaps a few more, in Hawaii.

This is a smaller number than were in the United States at the time the so-called gentlemen's agreement was concluded. Since that time more Japanese have come home from the United States than have gone there and the number in your country has been steadily reduced. 


\section{THE FALI OF TSINGTAU}

This reduction has been slow, it is true, owing to the fact that a good many Japanese in America get married and the birth of children tends to keep up the total number of Japanese there. But the influx of Japanese has been practically stopped and there is a gradual but steady reduction going on.

There is no real ground for apprehension, no real cause for alarm in the relations existing between the United States and Japan. I do not believe that Japan has, or ever had, any desire of warring with the United States. For economic reasons alone this appears to be true. Japan has not as yet recovered from her Russian war. Not one cent of the debt incurred in waging that conflict has yet been paid, and since that time the war operations at Kiaochow have indebted the Government still further. Further acquisition of territory necessitating large expenditures to the Government in its upkeep, both in Manchuria and Korea as well as in Kiaochow, have stripped the Japanese Treasury.

During that period the United States has been Japan's best customer. We have purchased raw silk and tea to the extent annually of more than sixty million dollars, and in so 


\section{JAPAN AND AMERICA}

doing have kept many thousands of people in Japan in employment in this trade. If war was to be declared between the two countries, this trade would come to a standstill, the Government would lose this income. Great Britain could not be used as the market for the once American tea-trade, for England has cultivated a taste for the better class of teas, either Indian or Chinese. Nor would England take up the importation of Japanese raw silk dropped by America, because they have found the Chinese silk more stable.

But the real question existing between Japan. and the United States, is the attitude of the two Governments toward China. On this point. rests the only true apprehension for fear of a war. Count Okuma, and other Japanese statesmen, know that in the California immigration question there are good points to be stated for both sides, and they realize that time alone can settle the matter in the peaceful way they are desirous that it shall be settled. In the question of China, however, the situation is more serious.

The United States is known among the 


\section{THE FALL OF TSINGTAU}

Powers as the true friend of China. It is a friendship not founded on petty jealousies or with any ulterior or base motive. It is a friendship always backed by friendly action of aid and guidance. Against the United States in this respect have stood out Russia and Germany, eager for China's partition, France, and Japan, with a dream of controlling China all for herself. And that is where the crux of American-Japanese relations lies to-day. It is the situation pending in Peking, as to whether or not the United States will attempt to interfere or block Japan's designs upon China, that lends the biggest support to this war talk between Japan and America.

In Japan this year, when her position toward China took on an ultimatum in the form of a series of demands, there arose among her prominent thinkers a cry, in answer to the protests of prominent Americans and Britishers, that Japan in these demands was only trying to formulate a Monroe Doctrine for Asia. From this there came forward a group of Americans who advocated that the United States should not interfere in any way with the Japanese 


\section{JAPAN AND AMERICA}

demands upon China lest it should prove dangerous to our own Monroe Doctrine.

"If Japan's only idea is to build up an Asiatic Monroe Doctrine," said Dr. Shailer Mathews, Dean of the University of Chicago, in March, after an eight weeks' American peace propaganda in Japan, "the American people can hardly fail to sympathize with her, particularly as we recall her need for territory in which to expand."

It is my belief that the Japanese demands upon China have nothing of Monroe doctrinism in them. They are simply aggressive measures forced upon China by Japan in an opportunity to realize her ambition for the domination of China, while the other Powers warring in Europe have their hands tied and cannot interfere.

The United States should not interfere, say many eminent Americans. Japan is only formulating a Monroe Doctrine in Asia.

But is she? Has our own Monroe Doctrine any imperialistic clauses like the following demands that Japan submitted to China? 


\section{THE FALL OF TSINGTAU}

China to purchase from Japan at least half of the arms and ammunition required by the whole country.

In regard to South Manchuria and East Mongolia, the railroads in this region to be exclusively under Japanese control for ninety-nine years, and no citizens or subjects of other countries to be allowed to build railroads or to make loans in this region without the consent of Japan.

Japanese capital to be employed for the development of the Province of Fukien.

In the Yangtze basin, Japan to have absolutely exclusive mining rights, and to be allowed to construct and control the main trunk lines from Central China to the coast and to the south.

Reducing China to a mere vassalage, threatening her very integrity, barring all foreigners but Japan, and closing the open door - all this Japan seeks in her demands upon China, and yet some Americans turn around and say, "Japan is following our Monroe Doctrine in Asia." I fail to see the similarity between Japan's policy and that doctrine laid down by our own President Monroe.

But what will be the result if the Japanese demands upon China prove successful? Millions of Chinese, chafing under the yoke of Japan, - a yoke which they never wanted, 


\section{JAPAN AND AMERICA}

which they dislike, which language and even religion separates them from. Sections of China will become a second Formosa, a second Korea, with Japanese armed guards standing about to keep the country from revolt. Will such conditions go on forever? I ask you, did they in Poland, did they in Alsace-Lorraine, in Trieste? All these last-named were foundation causes for the European war, and do you, as a peace-lover, want to see another Poland question and its like creep into Asia - later to take form in a giant holocaust in which the nations of the yellow race as well as nations of the white will participate?

That is the serious side of the AmericanJapanese relationship question. Will it become necessary for the United States to interfere in the Japanese demands?

Luckily there are other Powers, such as Great Britain and France, who are interested in the Japanese demands, and both will have some restraining influence upon the Nippon Government in the final negotiations at Peking. Undoubtedly Japan will see that any demands tending toward shutting the open 


\section{THE FALL OF TSINGTAU}

door in China any further than has already been done in Manchuria, will bring a strong protest from Great Britain and the United States. In such a case, if any friction should be developed between the two Powers and Japan over the question, it would probably tend toward a serious break between the United States and Japan, once the opportunity offered itself.

Germany's interference, together with that of France and Russia in the Treaty of Shimonoseki, whereby Japan was deprived of her spoils of the Chinese War, - the Liao-tung Peninsula, - is proof of this. Though Germany and Japan were in cordial relations at the time, though Germany tutored and brought the Japanese military establishment to its present first-class standing, Japan never forgot the Shimonoseki incident. Later, in August, 1914, Japan took the opportunity to avenge herself upon Germany.

But the United States has made clear to Japan, as well as to the other Powers, her policy toward China. Since Japan recognized that policy, her own policy toward China has been constantly undergoing shifts of position and 


\section{JAPAN AND AMERICA}

policy, until to-day, the American policy appears as a check to her desires. This injection of a disturbing element in the question of China by Japan causes both nations to become uneasy, and each suspects the other of bellicose designs against it as a result.

However, our attitude toward Japan is not bellicose. America has been somewhat awakened by the catastrophe that has befallen Europe, and she is naturally uneasy with the thought that some day, too, she may be involved in some such diplomatic planning as Europe witnessed in July and August which will turn her territory into turmoil. The natural result is to make military preparations to check such a tendency of affairs. But the sentiment, so necessary in Congress for taking these precautions, takes on such white heat that accusations are frequently made that Japan has bellicose designs upon America and we must prepare for them.

No such thing. Japan is fully aware that she has not the money or a cause successfully to wage war against the United States. Nor could she hope to gain anything by so doing. 


\section{THE FALI OF TSINGTAU}

With a population of $50,000,000$ people living on a group of islands about the size of the State of Montana, Japan is only looking forward to her future when she attempts to push her domains on to the continent of Asia. When she arose in 1905 as one of the first-class Powers, she discovered that Great Britain, Germany, Russia, and the remainder of the larger nations, had already played their game of grab, and the practice of foreign expansion was about at a standstill.

Nevertheless, realizing the unstable position of China, Japan stood guard at the door of Asia, and at the first sign of trouble from the nations within - Britain's war against Germany - she found an opportunity to get her much-desired Asiatic spoils through the AngloJapanese Alliance.

As to the California immigration question time alone will settle it satisfactorily both for Japan and the United States. But in Japan's ambitions in China and in the American attitude toward the Celestial Kingdom, there alone lies the danger of war between Japan and America. 


\section{CHAPTER XV}

\section{BUSHIDO vs. GREAT BRITAIN}

There is in Japan the lofty moral code of "bushido" or "the way of the warrior." The cherry blossom being, in the estimation of the Japanese, the purest and noblest among flowers, so the bushi, or warrior, is the purest and noblest among men. Wherever you go in Japan you hear prominent officials of the Mikado Empire refer to the bushido, this spirit, which, as they say, has played such an important part in the education, guidance, and training not only of the soldier and other individuals of Japan, but of the nation as well.

To have lived in Japan, to have worked among her people, bivouacked with her army, and to have resided among them in peace and in war, leads one to believe that there is very little in this far-famed bushido spirit of the Japanese.

As I sat one day on the beach of Lauschan, the base of supplies for the Japanese army in 


\section{THE FALL OF TSINGTAU}

Shantung, and watched hundreds of Chinese coolies ranging from young boys of fourteen years old to men of forty and fifty years of age, filing to and fro, carrying large, heavy crates on their bare backs, and with Japanese soldiers snickering and laughing as they beat them over the head and on the legs with thick bamboo sticks, I commenced to wonder what there was in this so-called spirit of bushido, this "way of the warrior," which is heralded all over the world as the fine, courteous, and manly spirit of the Japanese that has been so great a factor in bringing them into the limelight the last twenty years.

My residence in Japan, preceding that incident, had shown me that bushido certainly was not in daily practice about the cities and hamlets of Dai Nippon; at least my eyes had proved it otherwise. I wondered why it was that eminent writers of America and Great Britain had heralded this bushido spirit of the Japanese with so much praise and gratitude. Surely, the chivalry of the West, the code of the Occidental, is far more praiseworthy than that of the spirit of bushido, the Japanese code 

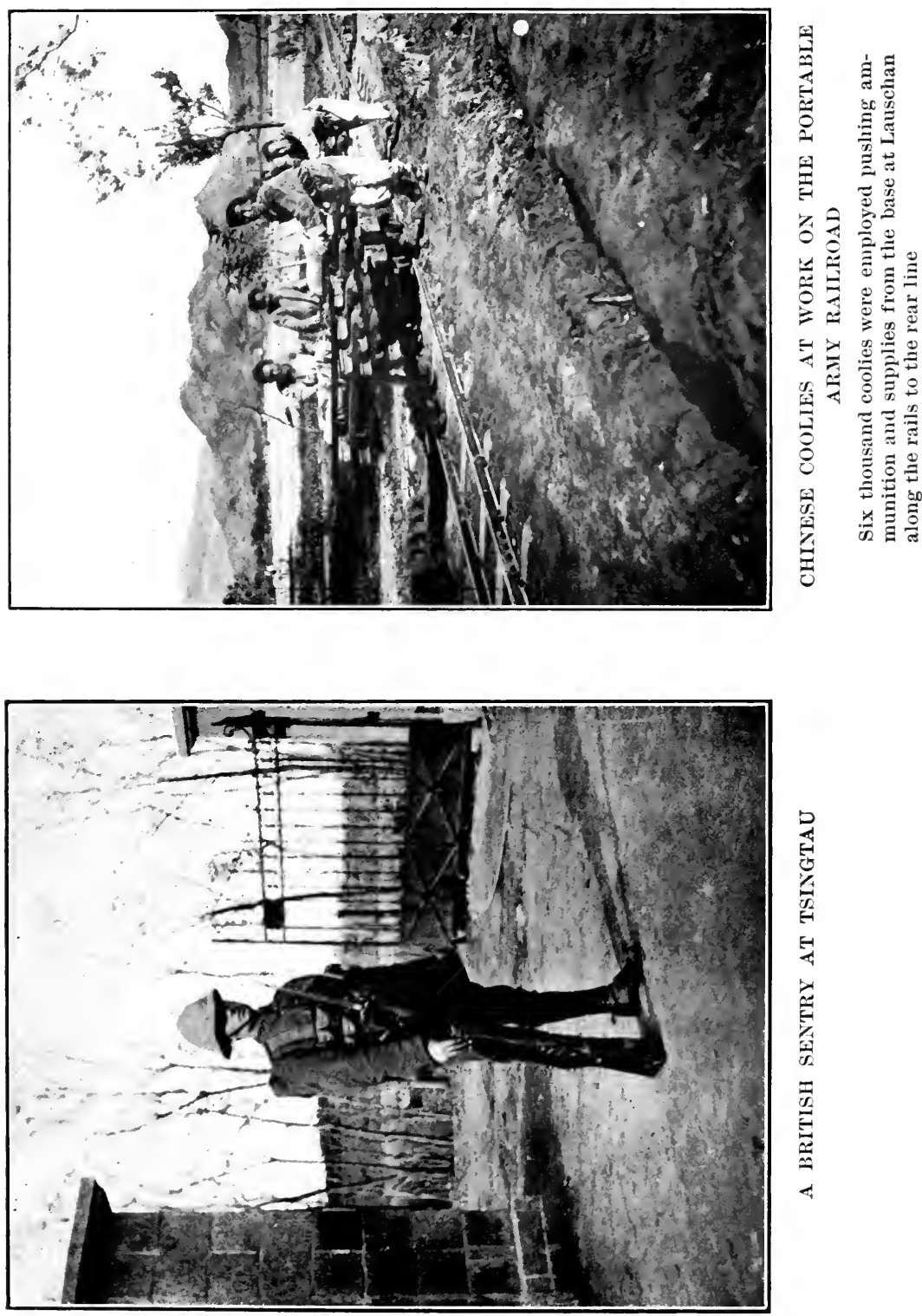

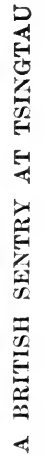




\section{BUSHIDO vs. GREAT BRITAIN}

of ethics. The Occidental, at least, considers it a duty to respect women, and his Government does not foster the concubinage system, nor does it have in its Government a cabinet known among the people as "the virtuous cabinet," such as the present Okuma Cabinet of Japan, so designated because preceding cabinets have been morally rotten. The chivalry of the West does not recognize a father who dissipates his wealth, and then turns his daughters out upon the streets to sell their chastity to pay his debts; but all this is allowable in Japan, this land of the bushido spirit.

And as I sat on the beach at Lauschan and watched the Chinese coolies working as hard and as fast as their strength would permit, in deadly fear of the soldiers standing about, I wondered why it was that Japanese soldiers stood along the line and beat them with sticks. I concluded, after an hour's observation of the sight, that it was just the tactics of a bully; the stronger showing his strength to the weaker brother in order that the latter would more readily understand who was boss.

Throughout my days with the Japanese 143 


\section{THE FALL OF TSINGTAU}

army in Shantung I found this constant nagging of the Chinese native by the soldiers of bushido. Sometimes it took the form of several Japanese pouncing upon a Chinese street peddler and robbing him of his wares; other times it was some soldier entering the house of a native, taking some piece of beautifully carved furniture, to be carted later into camp and utilized as firewood.

And then there was Japan's violation of China's neutrality, her occupation of western Shantung, and the ultimatum of "twenty-one demands" upon China, an uncalled-for procedure.

There is one nation, however, that is going to meet this spirit of bushido within the next ten or fifteen years, and that nation is none other than Great Britain. Already Britain's commercial interests are choking under the yoke of the Anglo-Japanese alliance, and with the Japanese even talking commercial invasion of the Yangtze valley, a British sphere of influence in China, it is wondered just how many years it will take for the friction that is now developing between the Japanese and 


\section{BUSHIDO vs. GREAT BRITAIN}

British interests to lead to something more serious.

Japan does not always apply a lofty moral code to her business. A few months' residence in the islands will prove this point satisfactorily. But from a Government standpoint, no nation will feel the Japanese business methods so quickly as will Great Britain. In fact the Foreign Office at London is probably a bit wiser on Japanese methods now than it was in 1911, when it signed the Anglo-Japanese Agreement. Perhaps this in part can account for the delayal of the publication by the Government in London of the book giving all the cablegrams and official messages that passed between Tokyo and London immediately before the Japanese participation in the European war. The Foreign Office under Sir Edward Grey has seen that copies containing the official messages that were exchanged between Belgium, France, Russia, and Turkey have been forwarded to every city of the world, outside of the German possessions, that boasts of a newspaper office. I have wondered just why a Government account, officially stating 


\section{THE FALL OF TSINGTAU}

the reasons for Japan's participation in the European war under the British Alliance, has never been published. Certainly Great Britain cannot say that Japan's joining the war was not as important as that of Turkey, or any other country.

There were many hitches and much wrangling between British officials and Japanese officials that first week in August when Japan, while Great Britain was still aroused from the shock of Germany's violation of Belgium's neutrality, asked London that she be allowed to drive Germany from Kiaochow, under the Anglo-Japanese Alliance. The Government business of Great Britain was more than crowded then with the mobilization and final preparations for her troops' invasion of continental territory. And it was while Great Britain's hands were practically tied at home with the worries and rush of events in Europe that Japanese diplomacy succeeded in putting through a move - her dream for years - an important domination of China. Undoubtedly Great Britain regrets it all, certainly her commercial interests do. 


\section{BUSHIDO vs. GREAT BRITAIN}

"Oh, the Anglo-Japanese Alliance; it's done everything for Japan and nothing for Great Britain," was the way one prominent British exporter in Yokohama put the matter to me. True, from a governmental standpoint it was the pretext used by Japan for driving Germany from Asia. But it is a question whether in the long run it has not been detrimental to British interests.

Until the present time British interests have dominated in the Far East. With her vast territory of India in Asia, the most important colonial possession she has, Great Britain wielded a leadership in the Far East that was felt from Persia to Japan. In banking, her Hongkong and Shanghai banking corporation, supported by the Chartered Bank, became the leading financial institution in the Far East. Though Japanese banks have been rising rapidly to importance, the British still control the large business interests in the Orient.

In shipping and trade, Great Britain is still in the front rank in Asia, but with the stupendous growth of Japanese commerce under able Government subsidy it is not known how long 


\section{THE FALL OF TSINGTAU}

this condition will remain. Japan's nearness to Asiatic markets and her cheap wage scale will play an important part in the increase of her trade and commerce, and with Germany now eliminated from Asia, it is expected Japan will make a strong bid for a part of that trade.

With the Tokyo Government in possession of Kiaochow, Japan will have a foothold in China on which to base her trade propaganda on a more extensive scale. Possibly she may make of it a second Manchuria for her tradespeople. While her diplomats shout the opendoor policy to the world, the Government furnishes rebates to its shippers, and slowly Japanese trade will come to the front as it has in Manchuria.

And it is these not too honest methods of the Japanese that are raising the ire of the British. Only last July the Shanghai branch of the China Association, composed of the most prominent British subjects in China, called a meeting to discuss the trade methods of Britain's ally.

"Gentlemen," read the chairman's report at the meeting, "if the Japanese competition is 


\section{BUSHIDO vs. GREAT BRITAIN}

strenuous because of improvements of their yarn and in packing, etc., we as Britishers ought to be able to stand the strain, and I have every confidence that we can do so; but if Japanese competition is to be reinforced by preferential rates of duty and preferential freights, we must protest and protest all the time and continue protesting until we can obtain a fair field and an equal opportunity for all."

In the one example of the sale of cotton goods to China, Japan during the last five years has cut into the trade of both Great Britain and the United States. In 1909, the British sold to China $10,690,000$ pieces, the United States 3,850,000 pieces, and Japan $1,390,000$ pieces of cotton goods. In 1913, Great Britain still led the field with the sale of $11,700,000$ pieces; the Japanese came next with $5,710,000$, while the sales from the United States had dropped to 2,280,000.

But the Japanese trader is a seeker after new fields. He is not content to develop his trade in his own sphere of influence, but will even wage war in the zones of other Powers. Just 


\section{THE FALL OF TSINGTAU}

before the opening of hostilities in Europe in July, Count Okuma, in an address in Tokyo, stated that he thought the time had come for the extension of the Anglo-Japanese Alliance to an economic alliance as well. He thought that Great Britain and Japan should coöperate in extending their trade throughout China and Asia, and only a few days later, the Premier's emissary to China, Baron Shibusawa, one of the most successful business men in Japan, said in an interview in Shanghai: "For the development of a country there are necessary three economic factors: resources, capital, and the knowledge and experience of men. China has many resources to be developed; the British have the capital, and the Japanese the knowledge and experience. There should be an economic coöperation."

"I recognize the importance of the British influence in the Yangtze valley," said Baron Shibusawa. "Each of the allies should, however, concede something to the other, for if not, a conflict of interest will take place."

The Yangtze valley, with Shanghai at its mouth and Hankow, six hundred miles farther 


\section{BUSHIDO os. GREAT BRITAIN}

inland, has long been recognized as the British sphere of influence in China. It is one of the richest valleys in the Celestial Kingdom, and it is not to be expected that British tradespeople in China look with any degree of delight upon Japan's aims to utilize her alliance with Great Britain as a factor in building up her commerce.

On these accounts friction is developing in the Far East between the British subject and the Japanese, and it is wondered whether Japan may not come out as leader in the Far East as a result of the European struggle.

It appears that the most influential factor that this question rests on is the military and naval strength of the two nations. Great Britain, at the close of the great war, will find thousands of her best-trained military men killed on the battlefields of Europe. In numerical strength she will probably be on a par with Japan, but the latter will have an advantage in her homogeneous force. Japan has no Indian regiments, no Canadian or Australian contingent to swell the strength of her army. Her soldiers are nearly all veterans of the Russian 


\section{THE FALL OF TSINGTAU}

war and her latest recruits have tasted war in the siege of Tsingtau. Her spirit is unified, and it is doubtful whether the mixed regiments that Great Britain will have are superior to the fighting force of Japan. Of the navies of the two nations Great Britain leads.

But events as they are happening in the Far East point to the end of the Anglo-Japanese Alliance upon the expiration of the present treaty in 1921. Other nations are clamoring to take the place of Great Britain in such alliance with Japan, not because they are pro-Asiatic in spirit, but because they want to weaken the power of Great Britain in order that they may further their own cause in the Far East. Japan, it is believed, is only too glad to accept some such proposal, for bushido, the way of the warrior, is not finding a welcome among British subjects. Is the time coming when Japan's late enemies, Russia and Germany, will be in league with the land of the Rising Sun, aiding them to drive Great Britain from the Far East? 


\section{CHAPTER XVI}

WHAT GERMANY DID IN KIAOCHOW

There have been few colonial ventures, such as Kiaochow, which have been blessed with such a fairy godmother as the Berlin Reichstag. During the seventeen years of occupation of the protectorate by Germany, no less than $\$ 60,000,000$ was showered on this Far Eastern naval base. Most of this expenditure went into docks, harbor improvements, Government buildings, schools, macadam roads, and the like, and though Germany has since been forced to surrender all this magnificent work, the Tsingtau of 1914 will clearly stand out in the memory of its visitors and Far Easterners as the finest, the prettiest, most modern and sanitary city in the Orient.

Germany at Kiaochow possessed two assets unequaled in the whole of Asia - one in the Bay of Kiaochow, and the opportunity it offered for a fine harbor near its entrance, and the other the climate of which the whole of 


\section{THE FALL OF TSINGTAU}

the Shantung Peninsula was able to boast. Perhaps in no other section of Asia is the climate so suited to the foreigner as that of Kiaochow, for, situated in about thirty-six degrees north latitude, which is about on an equality with the southern Azores and Gibraltar, it is noted in China for the mild temperature that prevails in the district practically throughout the year.

It did not take the Berlin Government long to utilize these two points in making Tsingtau, the capital of their new colony, the finest in the Orient. Scarcely before the terms of the Kiaochow Convention had been drawn up, transports and freighters were on their way from German ports to Shantung with lumber and other materials for setting up a model little European city. Along with them came all the best that Germany could give in geologists, engineers, and railroad constructors. In the short period of twelve months, the hills in the rear of Tsingtau were echoing with the chugs from the steam dredges working away on the bottom of the bay, and with the clatter of hammers from the fast-rising buildings about. 


\section{GERMANY IN KIAOCHOW}

For months and months the Germans labored hard to develop this harbor in Kiaochow Bay. The channel was at length cleaned out to permit the safe passage of the largest ship afloat, and the dredging work was then extended toward the construction of an outer and inner harbor at Tsingtau. At length the work was completed at an expense exceeding $\$ 7,000,000$. Under the eyes of Prince Henry, the Kaiser's brother, and commander of the German squadron that rode at anchor in the Bay of Kiaochow, this German naval base had become a reality.

The completion of the harbor work was followed by the erection of great granite piers and moles, so arranged that goods could be transferred directly from the railroad which was being proposed for construction into the hinterland. Military warehouses, foundries, machine shops, and electric power plant were then built, together with a floating dry dock capable of lifting the biggest dreadnought on the seas. Kiaochow was then ready to offer the best shipping facilities of any port on the China coast. 


\section{THE FAIL OF TSINGTAU}

With the final platting of the city of Tsingtau and with many of the governmental buildings that were to shelter the Government officials well under construction, Berlin turned attention to other propositions for developing the new colony. The attention of German capitalists was called to the wealthy province of Shantung, and on June 1, 1899, land operations at Kiaochow were stimulated by the formation in Berlin of the Shantung Railway Company.

On the same day this syndicate obtained the license for mining in Shantung, whereby the harmony necessary for the economic development of the protectorate was assured. The company, which was incorporated with a capital of $54,000,000$ marks, at once began the work of constructing a railroad from Tsingtau to Tsinan-fu, the capital of the province of Shantung, via Wei-hsien. The grading for the roadbed of the railroad began on September 23, 1899, at Tsingtau and Kiaochow, when His Royal Highness, Prince Henry, turned the first sod. The road, which was to be a single track, standard-gauge line, was rushed to completion 


\section{GERMANY IN KIAOCHOW}

with more than twenty-five thousand laborers employed, and by April 8, 1901, the first section of seventy-four kilometers to the town of Kiaochow was opened to traffic. Only sixteen months later the whole line from Tsingtau to Tsinan-fu, as well as a branch line from Changtien to the mining district of Poshan, was opened for freight and passenger traffic.

With Shantung now open to traffic and settlement, trade suddenly began springing up between the native and the German representatives. So pleased seemed the Reichstag over this turn of events that more coin was heaped upon the Kiaochow venture, and it was decided to cement a strong bond of friendship between their representatives and the Chinese. In this one instance the German Government invited the Chinese customs officials to function at Tsingtau under much the same rights and privileges as a German custom-house.

"The principal object of this arrangement," said Mr. Ohlmer, for long the Commissioner of Customs at Tsingtau, "was the creation and promotion of trade and commerce between the city and the Chinese hinterland. The results 


\section{THE FALL OF TSINGTAU}

conclusively proved the wisdom of this novel arrangement. Under it, trade developed beyond expectation, and Tsingtau, the former dilapidated fishing village, grew into a handsome city with a flourishing mercantile community, and a considerable number of manufacturing establishments. Its success emboldened the Government to agree to go a step farther and to arrange for the limitation of the free area, which formerly comprised the whole district, to the harbor, on much the same lines as at the German free ports, Hamburg and Bremen."

"The chief advantage of this step," said Mr. Ohlmer, "lay in the removal of customs control from the railway stations to the free area, and the consequent freedom of goods and passengers to pass in and out, from and to the hinterland, without hindrance and control of any kind - a traffic simplification from which a considerable increase of trade was expected. The expectation was realized, for the new arrangement inspired confidence and stability in the future of the port and in attracting artisans, traders, and wealthy Chinese firms, 


\section{GERMANY IN KIAOCHOW}

which last, hitherto dealing with Chefoo, until then kept aloof from the place."

In this way did Germany firmly establish itself among the Chinese, and with the embers of the Boxer Rebellion fast dying out, and the constant fear of the Celestial Kingdom at the rise of the Russian Government on its northern border, the two peoples seemed gradually to come together. Germany furthered the cause by sending to Kiaochow horticultural experts and scientists to aid the Chinese in their work of reclaiming Shantung, from which centuries before had spread China's religion, culture, and education.

The soil of the German protectorate, consisting as it did of granite rock and deposits of its decomposition, was found to be rich in potash, and with this as an inducement Germany set about to discover some means of reforesting the colony, something which all the Powers had tried a hand at in other sections of China with not much success. Park and experimental stations were platted and set with many of the Oriental trees and shrubs, as well as those imported from the fatherland, and under the 


\section{THE FALL OF TSINGTAU}

guidance of the horticultural experts the plants flourished and Germany was ready to carry its experiments farther into the hinterland.

But Tsingtau, the chief port of Kiaochow - already its name was being heard in the Far East and in Europe as a city of opportunity in the first five years of its existence found the Chinese and Japanese, as well as Germans and Britishers, all flocking to share in its trade. Tsingtau had by now passed from a city in the making to a modern European municipality with wide macadamized streets, four and five storied business blocks, and large, roomy stone residences, each of which looked fully capable of surviving the ninety-nine-year German lease of Kiaochow. Trains rumbled into its station from the hinterland, and the large concrete quays and docks along its shores were piled with crates containing goods and articles manufactured or raised in the district, awaiting shipment to the United States, South America, or Europe.

Along the water-front one found huge, long, gray military warehouses, machine shops of all kinds, and ship foundries. Along the dock of 


\section{GERMANY IN KIAOCHOW}

the greater harbor sailors passed to and fro, while a giant drydock anchored just beyond, in which was lashed a sixteen-thousand-ton North-German Lloyd vessel, gave the little city quite a commercial setting. Chinese sampans, heavily loaded with crates, glided quietly along in the bay, passed the German gunboats Iltis and Jaguar, and occasionally one would catch the deep undertoned oo of a Japanese freighter from Nagasaki, or a British vessel from Shanghai, as it signaled its entrance into the port to clear its goods. While Kiaochow Bay looks deep and trustworthy, it is, as a matter of fact, a great silt-choked expanse of sheltered water that Germany has had to dredge and make navigable for almost its entire extent. Its harbors and docks represent years of toil and great expenditures by the Reichstag; but the investments had proved their worth, for the little colony was prospering like no other settlement in the Far East.

By 1906, Tsingtau had witnessed the completion of its magnificent Government buildings whose Imperial crested gables seemed to flare forth from the hillside to greet the passen- 


\section{THE FALL OF TSINGTAU}

gers of incoming vessels. It had likewise built a fine naval hospital, schools for the Chinese as well as for the younger generation from the fatherland, and in fact all sides, commercial, economic, educational, and the religious side of life were all finding play-room in this Far Eastern city.

But it was not until after the close of the Russian-Japanese War that Tsingtau became known as the "Brighton" of the Far East. In view of the wonderful climate of this little city, Germany was not long in looking around to make it not only attractive enough to induce settlers from the fatherland to take up their residence there, but also to stimulate the traffic of the tourist with his wealth to the port. On the east beach of the outer bay, just a mile and a half from Tsingtau, German engineers soon discovered a delightful stretch of sand, more than a mile in length and facing out on the Yellow Sea. At once the making of Tsingtau the summer resort of the Orient entered into their minds, and but a year afterwards the surrounding country had been parked, bathhouses erected, the commodious Strand Hotel 


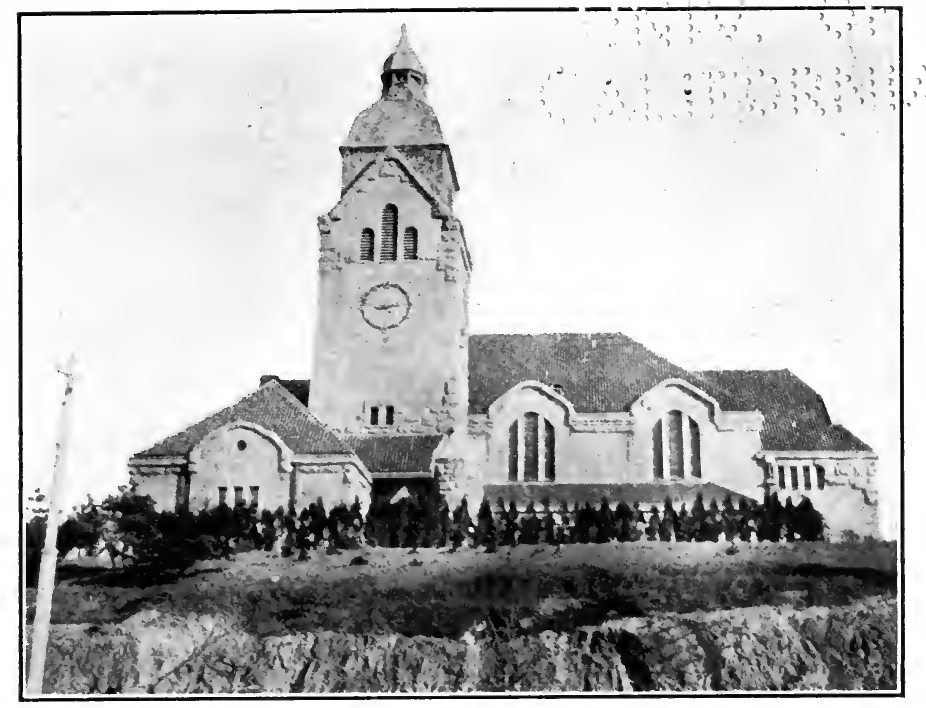

\section{CHRIST CHCRCH}

One of the few buildings in Tsingtau to go unscathed through the siege. A German Lutheran church on the outskirts of the city was all but demolished

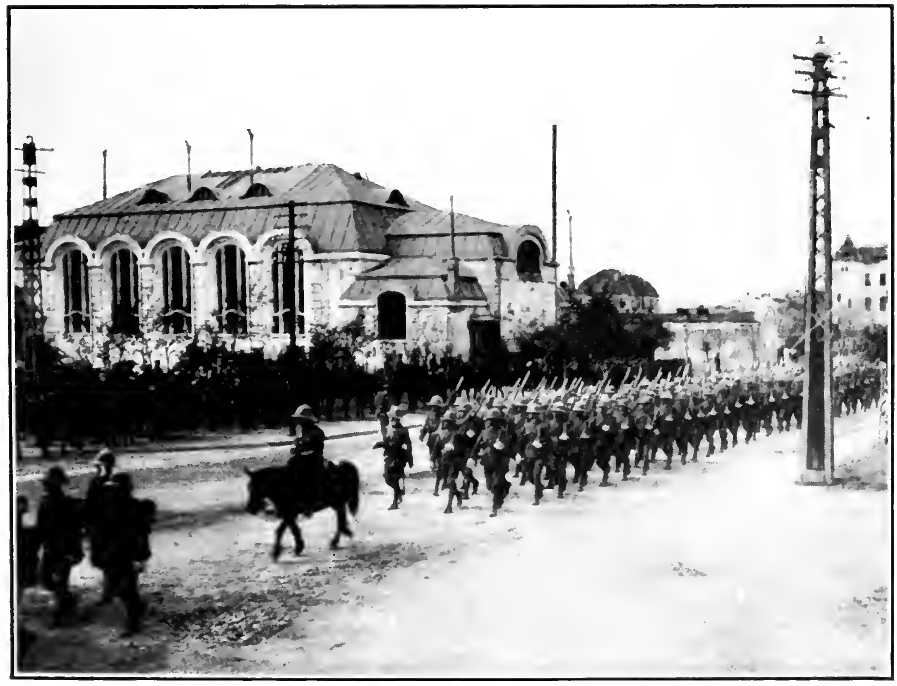

GENERAL BARNARDISTON AND THE BRITISH EXPEDITIONARY FORCE PASSING IN REVIEW BEFORE GENERAL KANIO

On the entry of the allied troops into Tsingtau, November 16,1914 . In the background is the Prince Heinrich Hotel, utilized by the Germans during the siege as an emergency hospital. The red cross painted on its roof preserved it from the bombs of Japanese aviators 
"yำ

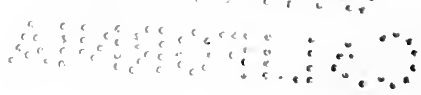




\section{GERMANY IN KIAOCHOW}

built, with accommodations for three hundred guests, a race-track course laid out near by; in fact all of the advantages of some of the "water-ways" in the fatherland were planted in the little colony. Closely following this came the wealthy German residents of Tsingtau, who built large villas, with beautiful gardens surrounding, on the heights, overlooking the beach. The city at once gained reputation, not only for great natural beauty, but for architectural beauty as well.

Gradually the news spread about in Far Eastern ports that Tsingtau was the healthiest city in Asia and was a delightful summer resort, with the result that the months of July, August, and September found American, British, German, French, and Chinese residents of Hongkong, Shanghai, Yokohama, and other Eastern ports all away from their sweltering climates and lounging comfortably about in the innumerable beautiful little villas of Tsingtau in its cool and delightful temperature. Each year saw the prestige of the colony in this respect rise, and soon the accommodations that the city could offer to guests were overtaxed. 


\section{THE FALL OF TSINGTAU}

More hotels were built, all on German lines, and modern in every detail, and soon the city began to take on a cosmopolitan appearance.

Along in the path of the summer resorter and tourist at Tsingtau came the Hindu, Chinese, and Japanese merchants with their bazaars, so familiar in Oriental ports, and gradually the city spread out to the top of the near-by rugged heights. Under German rule European ways had dominated Oriental customs in Tsingtau, and the port had become different from any other harboring place in the Far East. There was that same clatter of the bargaining native, the same rattle of the passing ricksha, but the beautiful paved and shaded streets, the purely foreign aspect of the city, with Germans, Britishers, and Americans passing down the streets, at once put the foreigner "at home" with the freedom and feeling that is rarely found by the newcomer in other cities of Asia. Ricksha coolies stood in an orderly row at a distance from the steamship gangplank as you passed down it, and there was none of that accustomed tripping and wrangling over passengers that is generally found in the Orient. The militaristic 


\section{GERMANY IN KIAOCHOW}

sway of Germany in Asia had evidently been felt by even the Chinese coolie.

For the Chinese native in Tsingtau, German officials had platted and fostered a model little hamlet called Tapatau, which is in itself a part of Tsingtau, but reserved for the business and residential purposes of the many Chinese who were living in the district at the time of the occupation. Here the same well-laid-out and paved streets are found. The Chinese homes are much more orderly kept than one sees in trips through other sections of the country. The population of Tapatau is about 30,000.

The population of Kiaochow in 1913 was estimated to be 191,984, an increase of fifteen per cent over 167,224 given out in 1910 . According to the census taken in Tsingtau in July, 1913, that city had a population of 60,484. In 1910 the census showed 40,264. The classification is as follows:-

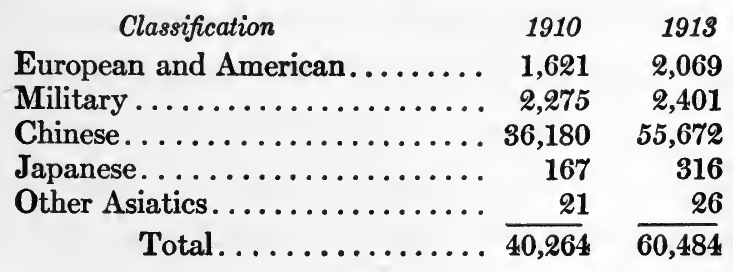




\section{THE FALL OF TSINGTAU}

The nationalities represented among the Europeans and Americans in the city during the last census were: German, 1855, Russian, 61, British, 51, Americans, 40, French, 15, other, 47.

Of the economic and commercial development of Kiaochow, much must be said of the mining that was carried on in the district during the sixteen years of German occupation. It was due probably to the eminent German geologist, Dr. Richtoffen, that the attention of the Government officials was called to the minerals of Shantung. After investigation it was estimated that the total amount of coal in the province was $10,000,000,000$ tons. The organization of the Shantung Mining Company was the result, with a capital of $12,000,000$ marks. On October 1, 1901, work was started on the Fangtze mine and the amount of coal dug out yearly increased until it reached 200,000 tons in 1911. In 1903, the company extended its operations to the Hungchang mine in Poshang, and in 1911, with a working force of 2500 Chinese, 375,000 tons of coal were extracted in the year. In spite of these resources the 


\section{GERMANY IN KIAOCHOW}

company operated at a loss of more than $\$ 10,000,000$ and in view of the situation the company was annexed to the Shantung Railway Company on February 13, 1912. Besides coal, Shantung Province is noted for the production of gold, silver, iron, copper, and lead. Petroleum has also been discovered in Kiaochow, since the Japanese occupation.

Other industries, which were fostered among the Chinese by the Germans, were the strawbraid trade, the production of American cotton and tobacco, the cultivation of silk, and the manufacture of pongee silk and hand-made lace. Poultry-raising has also been another big industry in Kiaochow, and in 1910, 1,821,183 dozens of eggs were exported to Russia and America from Tsingtau. The production of eggs in the province eventually led to the establishment of albumen factories, and in 1911 this production reached 500,000 pounds.

In horticultural lines the Chinese in Shantung owe much to Germany, for it was her officials who first introduced scientific farming into that province. Large orchards of apple trees, pears, pomegranates, chestnuts, peaches 


\section{THE FALL OF TSINGTAU}

set in rows and appearing not unlike the wellknown fruit orchards that exist in Hood River and in other sections of the western United States, were not an uncommon sight in the hinterland of Kiaochow during German occupation.

But just how Germany, with the natural advantage held in Kiaochow, routed the trade of other foreign countries, and especially the Japanese, from the province of Shantung, can probably be gleaned from a study of her shipping and export figures. In the year 1903, the total number of ships that entered Tsingtau was 277 and their aggregate tonnage reached 285,015 tons. In exactly ten years this number had almost trebled with the entrance of $\mathbf{7 9 9}$ vessels to the port with a total tonnage of 1,201,388. In 1903, foreign imports into Kiaochow amounted to 5,130,000 taels, with Chinese imports of $6,140,000$ taels additional. In 1913, this had been increased to $14,700,000$ and $16,620,000$ taels respectively. For the same period exports jumped from 230,000 taels to 9,150,000 taels, exclusive of Chinese exports, which were 15,840,000 taels additional. Pea- 


\section{GERMANY IN KIAOCHOW}

nuts, which are raised on an extensive scale throughout Kiaochow, furnished one of the main items in the exports from Tsingtau, 150,000 tons of these being exported to Europe in 1913.

In its sanitation, its modern sewers, its wellkept streets and houses - something that the foreigner finds the lack of in other sections of the Far East - in this respect Germany has shown that it can be done, that civilization can invade the sleepy and dreamy Orient and be successful. Other Powers have attempted many of the same things in their concessions in the Far East that Germany did in China, but none have really brought the Occidental and his ways to Asia, as the Germans did in Kiaochow. 


\section{CHAPTER XVII}

\section{JAPAN AND HER GAME IN CHINA}

THE European war furnished Japan with a rare opportunity, if such it can be called, for the encouragement of her designs upon China, which the Island Empire has cherished for the last ten years. Japanese statesmen saw in the hostilities in Europe during the first week of August "the chance of a lifetime" in Asia, for with the attention of all the Powers turned toward the Atlantic it left Japan to play her diplomacy as she saw fit. And Japanese statesmen were not slow in accepting the chance. Count Okuma, Premier of Japan, succeeded in throwing the United States and Great Britain off their guard by his messages of peace, and Japan "harbors no territorial aggrandizement," and the like. And so Japan was able to continue her game unhindered and unnoticed until events had gone too far for checking.

It may be a surprise to many to learn that the demands recently forced upon China by 


\section{JAPAN AND HER GAME IN CHINA}

Japan, which took on a serious warlike form early last May, were not of late making; that is, something that originated in the minds at Tokyo after the surrender of Tsingtau. In fact the Japanese demands upon China, while being held in mind for years, received no definite form until the first week in August. Japan at that time had received no answer from Great Britain as to whether her invitation to drive Germany from Asia would be accepted. But England, Germany, France, and Russia, all Powers interested in Asia, were at the time so busy, Japan seemingly could not act slowly, and so she decided to put in force her policy of the domination of China, before the other Powers should have a free hand to act.

The demands upon China, which were published in one of the vernacular papers in Osaka, at once threw China into great excitement. By the exposure of her cards, Japan was forced to revamp her policy in order to quiet the suspicions of Peking. Instead of playing her demands upon China first, Japan decided to work the cards somewhat under the veil of her war operations, and thus originated the Japa- 


\section{THE FALL OF TSINGTAU}

nese violation of China's neutrality by her army a few weeks later.

The first demands made upon Peking by the new Japanese Ambassador, Mr. Hioki, were six in number, according to which Japan undertook "to secure effectively the independence of the Republic of China." In thedemands as published throughout the China press at the time, but which Government suppression kept from all but one Japanese newspaper, Japan agreed "to take steps to meet the emergency should any third nation want to disturb the peace of the Republic." For Japan's "kindness" in this matter China was to agree "not to hinder the movements of the Imperial Japanese Government, but to compensate it for its services, and allow it to use any strategic points necessary for military service." In other words, Japan hoped to dominate China by first getting her army into the Celestial Kingdom without suspicion, and then, with a gun pointed at the head of China, would declare: "Here, you give us what we want or we'll blow your head off."

But China, and the Far East outside of Japan, look with distrust upon Japan's ac- 


\section{JAPAN AND HER GAME IN CHINA}

tions, a suspicion seemingly well founded on policies that Japanese statesmen have committed their Government to during the last twenty years. And so Premier Okuma veiled the policy of Japan in a message to the American public which, as printed in "The Independent" of August 24, stated: "As Premier of Japan, I have stated, and I now again state to the people of America and of the world, that Japan has no ulterior motive, no desire to secure more territory, no thought of depriving China or other peoples of anything which they possess."

Then began the Japanese army movements in their strangle-hold method upon China. They landed their troops at Lungkow, marched into the hinterland, and instead of working toward Tsingtau, the Japanese army turned its back on the German garrison and marched westward, thus violating the neutrality of China. Though the latter protested vehemently, Japan went ahead and marched her troops still farther westward, out of the war zone, to Tsinan-fu, the capital of Shantung.

The Far East now knew what the future held 


\section{THE FALL OF TSINGTAU}

in store for China. But China, in deadly fear of a revolutionary uprising against the invader, and with the one object of saving if possible her people of Shantung from the horrors of war, declared a war zone. To this zone Japan paid not the least attention, but marched her troops about as if Shantung was in reality Japanese territory. It seized the Shantung railroad, a Chino-German private concern, the valuable coal mines belonging to the company, and committed many acts of violence and force upon the once peaceful Shantung communities which aroused the ire of not only the Chinese, but the British, their allies, as well.

But all this was without effect on Japan. She continued to act with high-handedness. With the final transfer of the German government, Japan placed military rule over Kiaochow with General Kamio as its Governor-General.

Then began the unfolding of Japan's policies, which, unless altered, will bar her in the future from the trusted round table of nations. When the question of the Tsingtau Maritime Customs Office arose, Japan objected to the 


\section{JAPAN AND HER GAME IN CHINA}

policy of China in the appointment of customs officers, a policy which all the Treaty Powers guaranteed, and instead insisted that the officials be appointed only from the Japanese Customs Department. It will be noted that by the peace protocol of the Boxer Rebellion the customs revenue of China was assigned to the indemnity. Kiaochow, even under German occupation, had never ceased to be Chinese territory, and as such, all its customs revenue went to the Peking Treasury.

For weeks the matter was argued, China attempting to offset any desires of Japan for the impairment of her sovereign rights. But though China agreed to permit eight members of the Imperial Japanese Customs Department to functionate with the Chinese customs service at Tsingtau, Japan would have none of it, and finally forced the point by placing all Japanese officers in the Tsingtau Customs Office.

Next she permitted only Japanese vessels to call at the Kiaochow port. Great Britain protested, and Japan replied with one of her characteristic notes that the Bay of Kiaochow was still mined and that it would be dangerous to 


\section{THE FALL OF TSINGTAU}

permit shipping to go on at the port. The demands of British commerce, however, took on a serious form at the London Foreign Office, and at length Japan decided to permit British vessels to call at Tsingtau. At this time of writing the ships of other nations are still barred.

To understand fully the actions of Japan during the last ten months, it is necessary to get a glimpse of the political situation in Tokyo during December. In the Diet which was in session that month the strongest party numerically was the Seiyukai. It was strongly opposed to the Okuma Cabinet, and with that Cabinet dictating the policy that Japan was following, it was feared that the Seiyukai, during the session, would attempt to cause the Cabinet's downfall.

The Seiyukai especially were clamoring against the weakness of the foreign policy of the Cabinet in permitting Great Britain to dictate that Japan would "eventually" restore Kiaochow to China, and with the newspapers supporting them with bellicose editorials against the Cabinet, the Government's policy seemed on the verge of failure. 


\section{JAPAN AND HER GAME IN CHINA}

The delay in bringing about the conclusion of the siege of Tsingtau, until three weeks before the reassembling of the Diet in Tokyo, helped in a small degree to check the public disapproval of the Cabinet, but not until December 9, when Baron Kato, Foreign Minister, before an audience hissing and muttering, announced to the world that Japan had never guaranteed to any nation eventually to restore Kiaochow to China, did the feeling against the Cabinet subside. I was present in the Diet that day and noticed that twice in the course of his speech, Baron Kato was forced to stop to warn Diet members who were uttering aloud insulting remarks about him.

The statements of Baron Kato that day revealed the messages of Premier Okuma to be mere diplomatic chaff, covering selfish national ambitions. But the utterances of Baron Kato in the Diet were as much a surprise to the Japanese as to the rest of the world. The vernacular press of Tokyo came out the following day with editorials in which they stated that, while Baron Kato's statement was a complete revelation to them, they were glad to hear that 


\section{THE FALL OF TSINGTAU}

the Foreign Office had not been committed to any weakened policy as had been supposed.

From that day on the opposition to the Okuma Cabinet commenced to dwindle, and throughout the next three months of campaigning the Government was able to come out victorious in the elections of March 26 by appealing to the patriotism of citizens to support the policy of the Government.

China and the Far East in general were now aware that Japan had practically decided to make Shantung a Japanese sphere of influence. The Japanese press was alive with interviews of prominent Japanese officials in which the future actions of Japan were all revealed.

"We must take it upon us to manage and develop Shantung Province, and this by no other power than that of commerce and industry," said Baron Sakatani, Mayor of Tokyo and former Minister of Finance. It will be noted in the above that it is not alone Kiaochow that is to be managed by Japan, but all of Shantung.

"That our country has come across such a great opportunity is a consequence of the war 


\section{JAPAN AND HER GAME IN CHINA}

which caused the withdrawal of European commerce from China," wrote Mr. Hikokichi Ijuin, former Japanese Ambassador to Peking, in the December issue of the "Japan Financial Monthly." "The opportunity is indeed rare and will occur only once in a great while. Therefore we must take a step forward and grasp it firmly. And let us do so quickly. If we incur a delay here, the armed contest will cease and the European commercial giants will turn to China with redoubled force. Then the mighty opportunity will be lost forever."

Mr. Ijuin apparently does not think that a policy as outlined by one of the Japanese statesmen, Premier Okuma on August 24, as to the future restoration of Kiaochow, is to be taken seriously. And then Mr. Shirani, Civil Administrator of Kwantung Peninsula, is somewhat in touch with the Government's hidden policy when, in December, he asks: "Will Kiaochow become an equally promising colony for our people as Formosa or Manchuria?" And then he discusses the question at length with a negative answer.

And thus, after the surrender of Tsingtau, 


\section{THE FALL OF TSINGTAU}

we see the Japanese leaders of finance and economics all discussing the question of Shantung and Kiaochow and what Japan can do with it in the future to build up its empire.

That Japan was bent upon the policy, as outlined above by some of her leading government and commercial thinkers, was at length revealed on January 18, 1915, in the second presentation by Japan of demands upon China. Those who violate the laws of man, either internationally or socially, generally use the cover of darkness for their crimes, and so it was with Japan in the presentation, through Mr. Hioki, the Japanese Ambassador at Peking, of a series of twenty-one demands, most preposterous in character.

Japan, in the presentation of the demands, insisted that they should not be made known, and further stated that if China disregarded the warning she would be punished by much more drastic measures. But Japan, instead of presenting the demands to the Minister of Foreign Affairs at Peking, the usual order of things, took extra precautions this time, lest the world should learn the truth, and instead, they were 


\section{JAPAN AND HER GAME IN CHINA}

presented directly to President Yuan Shi-Kai. Late the same evening Mr. Hioki had an interview with the President and explained in detail the demands. 


\section{CHAPTER XVIII}

\section{THE PASSING OF CHINA AS A SOVEREIGN NATION}

In the history of nations, there has never been a document presented to a sovereign State by another, such as the demands Japan presented to China on January 18, 1915. Guiltless of offense was China, but Japan, with no shadow of excuse, presented to her a document which has all but robbed the Celestial Kingdon of sovereignty. It was an event of world-wide importance, but so interested were the United States and the other Powers in the tragedies that were happening on the other side of the world, that Japan's death-blow to China and the passing of the oldest nation in the world is scarcely yet realized.

And in the presentation of her demands, Japan unmasked before the whole world to reveal herself purely as a military nation, bound by no honor and guided simply by her selfish ambitions. I state this as a fact and with no unfriendliness to Japan. 


\section{THE PASSING OF CHINA}

But of the Japanese ambition to dominate China: It is a desire not of recent invention, but as old as the New Japan. For years Japan has worked to realize this dream. China has been flooded with spies under the disguise of students or priests, all of whom have traveled the country from province to province, noting the military conditions and otherwise preparing data which would prove beneficial when once Japan was ready to put her policy in force. At Hankow, in the very heart of China, the Tokyo Government erected a large military barracks with the pretext of protecting her concessions in that district, but with the intention of utilizing this strategic point as a base for her military operations later, if the domination of China required military force.

And let the reader remember that the Japanese domination of China was fully discussed by the Powers at the close of the Chino-Japanese War in 1895. One of the demands made by Japan upon China at the treaty negotiations conducted at Shimonoseki at the conclusion of that war was the cession to Japan of the Liaotung Peninsula, which included Port Arthur. 


\section{THE FALL OF TSINGTAU}

When the news of the Japanese treaty demands upon China were known to the rest of the world, Europe especially was at fever heat. Russia at once assumed a hostile attitude toward Japan and rushed a fleet of seventeen warships to Chefoo Harbor, at the same time instructing China not to ratify the treaty. Russia in her move to check the aspirations of Japan was naturally supported by her ally, France, as well as Germany, all seeing in the Japanese desires the domination of China. It was understood then that the Power which controlled Port Arthur would control Peking, and hence it was that the three above-mentioned Powers presented to Tokyo a brief communication which stated that, as the Japanese position on the mainland would "not only constitute a constant menace to the capital of China" and "jeopardize the permanent peace of the Far East," it was deemed important by these Powers, "in a spirit of cordial friendship," to insist that Japan "renounce the definite possession of the Liao-tung Peninsula." With all the above military talent arrayed against her, there was only one move open to Japan - 


\section{THE PASSING OF CHINA}

the retrocession of the Liao-tung Peninsula, the key to Peking, and though the blow was a heavy one to the aspirations of Japan, she bowed down to humiliation, with the one thought that she would take her score later. The defeat of Russia and Germany, the two main Powers which took an active part in the ratification of the Chefoo treaty, has since paved the way for the Japanese control of Port Arthur and Peking, at the same time wiping out the humiliation that these two Powers forced Japan to undergo in 1895, when she was still an embryo military State.

In the previous chapter it was stated that on the evening of January 18, 1915, Mr. Hioki, Japanese Ambassador to Peking, called upon President Yuan Shi-Kai and presented to him a document containing the most sweeping and drastic measures. The following, which is an officially verified translation of the identical note presented to the President of China by the Japanese Minister on that date, will best show the reader just how far the dream of the domination of China is outlined by Japan. 


\section{THE FALL OF TSINGTAU}

Group I. The Japanese Government and the Chinese Government, being desirous of maintaining the peace of Eastern Asia and of further strengthening the friendly relations existing between the two neighboring nations, agree to the following Articles: -

Article I. The Chinese Government agrees that when the Japanese Government hereafter approaches the German Government for the transfer of all rights and privileges of whatsoever nature enjoyed by Germany in the Province of Shantung, whether secured by Treaty or in any other manner, China shall give her full assent thereto.

ARticle II. The Chinese Government agrees that within the Province of Shantung and along its sea border no territory or island or land of any name or nature shall be ceded or leased to any third Power.

Article III. The Chinese Government consents to Japan building a railway from Chefoo or Lungchau to join the Tsinan-Kiaochow Railway.

ARticle IV. The Chinese Government agrees that for the sake of trade and for the residence of foreigners certain important places shall be speedily opened in the Province of Shantung as treaty ports, such necessary places to be jointly decided upon by the two Governments by separate agreement.

Group II. The Japanese Government and the Chinese Government, since the Chinese Government has always acknowledged the specially favorable position enjoyed by Japan in South Manchuria and Eastern Inner Mongolia, agree to the following Articles:- 


\section{THE PASSING OF CHINA}

Article I. The two contracting Powers mutually agree that the term of lease of Port Arthur and Dalny and the term of lease of the South Manchuria and Antung-Mukden Railways shall be extended to the period of ninety-nine years.

Article II. Japanese subjects in South Manchuria and Eastern Inner Mongolia in erecting buildings for the purpose of trade and manufacture or for farming shall have the right to lease or own land so required.

ARTicle III. Japanese subjects shall be free to reside and travel in South Manchuria and Eastern Inner Mongolia and to engage in business and in manufacture of any kind whatsoever.

Article IV. The Chinese Government agrees to grant Japanese subjects the right of opening all mines in South Manchuria and Eastern Inner Mongolia, such mining places to be jointly decided upon by the two Governments.

Article V. The Chinese Government agrees that in respect of the two following subjects mentioned herein below the Japanese Government's consent shall be first obtained before action shall be taken:

(a) Whenever permission is granted to the subject of a third Power to build a railway or make a loan with a third Power for the purpose of building a railway in South Manchuria and Eastern Inner Mongolia.

(b) Whenever a loan is to be made with a third Power pledging the local taxes of South Manchuria and Eastern Inner Mongolia as security.

Article VI. The Chinese Government agrees 


\section{THE FALL OF TSINGTAU}

that if the Chinese Government in South Manchuria or Eastern Inner Mongolia employs advisers or instructors for political, financial, or military purposes the Japanese shall first be consulted.

Article VII. The Chinese Government agrees that the control and administration of the KirinChangchau Railway shall be handed over to the Japanese Government to take effect on the signing of this agreement, the term to last for ninety-nine years.

Group III. The Japanese Government and the Chinese Government, seeing that Japanese financiers and the Hanyehping Company have close relations with each other at present, and also desiring that the common interests of the two nations shall be advanced, agree to the following Articles:

Article I. The two contracting Powers mutually agree that when the opportune moment arrives the Hanyehping Company shall be made a joint concern of the two nations and they further agree that without the previous consent of Japan, China shall not by her own act dispose of the rights and property of whatsoever nature of the Hanyehping Company, nor cause the said Company to dispose freely of the same.

Article II. The Chinese Government agrees that all mines in the neighborhood of those owned by the Hanyehping Company shall not be permitted without the consent of the said Company, to be worked by other persons outside of the said Company, and further agrees that if it is desired to carry out any undertaking which it is apprehended may directly or indirectly affect the interests of the 


\section{THE PASSING OF CHINA}

said Company the consent of the said Company shall first be obtained.

Group IV. The Japanese Government and the Chinese Government with the object of effectively protecting the territorial integrity of China agree to the following special Article:-

The Chinese Government agrees that no island, port, and harbor along the coast shall be ceded or leased to any third Power.

Group V. Article I. The Chinese Central Government shall employ influential Japanese as advisers in political, financial, and military affairs.

ARTICLE II. In the interior of China, Japanese shall have the right to ownership of land for the building of Japanese hospitals, churches, and schools.

Article III. Since the Japanese Government and the Chinese Government have had many cases of dispute between the Japanese and Chinese police to settle, cases which cause no inconsiderable misunderstanding, it is for this reason necessary that the police departments of important places (in China) shall be jointly administered (by Japanese and Chinese) or that the (Chinese) police department of these places shall employ numerous Japanese for the purpose of organizing and improving the Chinese police service.

Article IV. China shall purchase from Japan a fixed ratio of the quantity of munitions of war (say fifty per cent or more), or Japan shall establish in China a jointly worked arsenal, Japanese technical experts to be employed and Japanese material to be purchased. 


\section{THE FALL OF TSINGTAU}

Article V. China agrees to grant to Japan the right of constructing a railway connecting $\mathrm{Wu}$ chang with Kiu-kiang and Nan-chang. Also a line between Nan-chang and Hang-chow, and a line between Nan-chang and Chao-chow.

Article VI. China agrees that in the Province of Fu-kien Japan shall have the right to work mines and build railways and to construct harbor works (including dockyards), and in case of employing foreign capital Japan shall be first consulted.

Article VII. China agrees that Japanese subjects shall have the right to propagate religious doctrines in China.

While Japan had desired not to make the note of demands public, and had warned China that dire results would follow if she made known to outsiders the negotiations, reports of the demands, in some way or other, as such acts of secrecy do, gradually crept out, and in a short time they were known to the whole world.

So drastic were the Japanese demands, once they became known abroad, the Powers commenced to dispatch official inquiries to the Tokyo Government, which in turn sent back the following interpretation of the demands. The reader is asked kindly to compare the copy of the original Japanese demands with the seemingly little trivial communiqué that 


\section{THE PASSING OF CHINA}

was dispatched by the Japanese Government to the Powers and which was as follows:-

I. In relation to the Province of Shantung:-

1. Engagement on the part of China to consent to all matters that may be agreed upon between Japan and Germany with regard to the disposition of all rights, interests, concessions which, in virtue of treaties or otherwise, Germany possesses in relation to the Province of Shantung.

2. Engagement not to alienate or lease upon any pretext the Province of Shantung, or any portion thereof, or any island lying near the coast of the said province.

3. Grant to Japan the right of construction of a railway connecting Chefoo or Lungkow and the Tsinan-Kiaochow Railway.

II. In relation to South Manchuria and Eastern Inner Mongolia: -

1. Extension of the terms of the lease of Kwangtung, the South Manchuria and the AntungMukden Railway.

2. (a) Acquisition by the Japanese of the right of residence and ownership of land. (b) Grant to Japan of the mining rights of the mines specified by Japan.

3. Obligation on the part of China to obtain in advance the consent of Japan before she grants railway concessions to any third Power, procures the supply of capital from any Power for the construction of a railway, or raises from any third Power a loan on security of any duties or taxes.

4. Obligation on the part of China to consult 


\section{THE FALL OF TSINGTAU}

Japan before employing advisers or tutors regarding political, financial, or military matters.

5. Transfer of the management and control of the Kirin-Changchau Railway to Japan.

III. Agreement in principle that at an opportune moment in the future the Hanyehping Company shall be placed under Japanese and Chinese coöperation.

IV. Engagement, in accordance with the principle of maintenance of the territorial integrity of China, not to alienate or lease any ports or bays on, or any island near, the coast of China.

In other words, Japan, when pressed by the United States and the other Powers as to her intentions in China, stated that the demands then under negotiation were ten in number and that the other eleven so-called demands, of which the Powers had received reports, were not demands at all, but only requests. The actions of the Japanese Government during the following negotiations at Peking proved the above statement, relative to the eleven "requests," not to be true.

But with all the publicity that had been thrown upon the twenty-one demands, Japan continued to press the negotiations, threatening China with force if she did not agree to 


\section{THE PASSING OF CHINA}

them. The question at length dragged into the month of April with more than twenty-five meetings of the Japanese Ambassador and the Chinese Minister of Foreign Affairs.

Great Britain by this time was stirred up over the matter, and especially in the industrial cities, such as Manchester, were the Peking negotiations invested with tremendous importance. Likewise did the commercial interests of Great Britain, having an investment in the Yangtze Valley and other sections of more than $400,000,000$ pounds sterling, inquire into the Japanese demands upon Peking. The British Parliament was constantly reminded by questions of its members that the people should be told exactly what was happening in the Far East. In reply to these questions Premier Asquith told of the messages that had been forwarded to him from Tokyo, all of which were very meager and did not touch at all the demands that Japan was attempting to force China to accede to. Nor in his parliamentary addresses did Premier Asquith refer to the note of alarm which the British and Russian Ambassadors at Tokyo 


\section{THE FALL OF TSINGTAU}

had presented to Baron Kato, the Japanese Foreign Minister, the latter part of March.

The note presented to the Tokyo Government by the representatives of the two Powers informed the Japanese Foreign Minister that, "If Japan persists in pressing its demands on China beyond those contained in the original communication to the Powers, it will be difficult for Japan's allies to negotiate diplomatically with her in the future."

It was not until the last week in April, however, that anything definite was realized by Japan relative to her demands upon Peking. During that period China had agreed to the first paragraph of Article I of the demands, but still held back on the others of that clause. As South Manchuria has been a part of the Japanese nation in all but name for the last ten years, China practically conceded all of Group II to Japan.

As to the other groups of the demands China refused to listen, and no form of parleying by Mr. Hioki would seemingly move Peking from its viewpoint. Mr. Hioki then resorted to stratagems, to make China appear technically 


\section{THE PASSING OF CHINA}

wrong on several points. In this way a pretext could be raised for requiring China by force to accede to all of the demands.

On this point China held ground, realizing that with her sovereignty threatened, she could ill afford to play a foolish rôle in the matter. And with the matter thus deadlocked, with the negotiations practically at a standstill, Japan found herself in a serious position.

The negotiations were daily getting more publicity, something that Japan had tried to guard against; truth was constantly finding the light and forcing Japan into a backward position. In order not to alarm the Powers and to reveal the diplomacy that she had been practicing, Japan found only one course open. That was to continue to keep secret the documents that would reveal the whole truth of the Peking negotiations, at the same time distributing throughout the world her own description of the matter - a description naturally favorable to Japan.

In the mean time British commercial agents in China had been forwarding to London reports of the negotiations as gathered at Peking. 


\section{THE FALL OF TSINGTAU}

Especially did the demands under Group III and $\mathrm{V}$ receive their condemnation. It will be noted that these demands, the most drastic of the twenty-one, were the ones that Japan had taken special pains to see were not included in her official report of the matter to the Powers.

Now the district about Hankow, where are located the Hanyehping mines, being one of the wealthiest mineral districts in the world, and possessing iron as well as coal and lime pockets, all the ingredients in the making of iron and steel, Japan realized that it was of great importance that she should take control of this mining concession if she was to have the steel for military equipment which is highly essential if she is to become one of the dominating Powers of the world. And Japan at present, having to import more than seventyfive per cent of the iron and steel she uses, looked upon the Hanyehping mines as a necessity.

That the reader may better understand the Japanese demands made upon China embodied in Group $\mathbf{V}$ of the twenty-one demands, I ask that he imagine Mexico a civilized Power - 


\section{THE PASSING OF CHINA}

that is, where military matters are concerned; that he imagine the United States, not as the Power that she is, but just a big nation, teeming with people, peaceful in their pursuits, and attempting gradually to rise from a form of semi-civilization to that of a nation of unlimited possibilities.

Then some fine day, out of a clear sky, while the United States is busy toiling, imagine Mexico suddenly hurling at our country a note in which she asks of the United States: That it appoint Mexican advisers in political and financial affairs as well as in all military matters; that the United States employ Mexican policemen in its departments in New York City, Philadelphia, Washington, Boston, and the other large centers of its country for the purpose of organizing and improving the police service of the country; that the United States buy fifty per cent of her munitions of war from Mexico, or that there be established an arsenal jointly worked by both nations, Mexican technical experts to be employed and the material to be purchased likewise from Mexico; - in other words, that Mexico should have complete 


\section{THE FALL OF TSINGTAU}

control of the military affairs of the United States.

If such a thing came about in the United States, would it be considered an action tending toward the "peace of North America"? Yet this is exactly what Japan has attempted to foist upon China.

It is not to be wondered at that China refused to consider the demands that deprived her absolutely of sovereignty. Japan, realizing that she excelled China in perseverance, still hung to her point, hoping the latter would weaken.

But China held, and as publicity on the negotiations was constantly gaining headway abroad, Japan slackened her course with the following set of modified demands delivered at Peking on April 26:-

Group I. The Japanese Government and the Chinese Government, being desirous of maintaining the peace of Eastern Asia and of further strengthening the friendly relations existing between the two neighboring nations, agree to the following Articles: -

Article I. The Chinese Government agrees that when the Japanese Government hereafter ap- 


\section{THE PASSING OF CHINA}

proaches the German Government for the transfer of all rights and privileges of whatsoever nature enjoyed by Germany in the Province of Shantung, whether secured by treaty or in any other manner, China shall give her full assent thereto.

Article II. The Chinese Government engages that within the Province of Shantung and along its sea border no territory or island or land of any name or nature shall be ceded or leased to any third Power.

Article III. The Chinese Government consents that as regards the railways to be built by China herself from Chefoo or Lung-chau to connect with the Tsinan-Kiaochow Railway, if Germany is willing to abandon the privilege of financing the said lines, China will approach Japanese capitalists to negotiate for a loan.

Article IV. The Chinese Government engages, in the interest of trade and for the residence of foreigners, to open by herself as soon as possible certain suitable places in the Province of Shantung, as commercial ports.

\section{The Following to be the Subject of an ExchaNge of Notes}

The places which ought to be opened are to be chosen and the regulations to be drafted by the Chinese Government, but the Japanese Minister must be consulted before making a decision.

Group II. The Chinese Government and the Japanese Government, with a view to developing their economic relations in South Manchuria and 


\section{THE FALL OF TSINGTAU}

Eastern Inner Mongolia, agree on the following Articles:-

Article I. The two contracting Powers mutually agree that the term of lease of Port Arthur and Dalny and the term of lease of the South Manchuria and Antung-Mukden Railways shall be extended to the period of ninety-nine years.

Article II. Japanese subjects in South Manchuria may lease or purchase necessary land for erecting suitable buildings for trade and manufacture or for prosecuting agricultural enterprises.

Article III. Japanese subjects shall be free to reside and travel in South Manchuria and to engage in business and in manufacture of any kind whatsoever.

The Japanese subjects referred to in the preceding two articles besides being required to register with local authorities passports, which they must procure under the existing regulations, shall also observe police laws and ordinances and tax regulations which are approved by the Japanese Consul.

Civil and criminal cases in which the defendants are Japanese shall be tried and adjudicated by the Japanese Consul; those in which the defendants are Chinese shall be tried and adjudicated by Chinese authorities. In either instance the authorities on the plaintiff side can send a delegate to attend the proceedings; but mixed civil cases between Chinese and Japanese relating to land shall be tried and adjudicated by the delegates of both nations conjointly in accordance with Chinese law and local usage. When the judicial period in the said region is completely reformed, all the civil and criminal 


\section{THE PASSING OF CHINA}

cases concerning Japanese subjects shall be tried entirely by Chinese law courts.

Articles IV, V, VI, VII, "initialed" as in previous demands.

\section{Relating to Eastern Inner Mongolia}

1. The Chinese Government agrees that whenever a loan is to be made with a third Power, pledging the local taxes of Eastern Inner Mongolia as security, China must negotiate with the Japanese Government first.

2. The Chinese Government agrees that China will herself provide funds for building the railways in Eastern Inner Mongolia; if foreign capital is required she must negotiate with the Japanese Government first.

3. The Chinese Government agrees, in the interests of trade and the residence of foreigners, to open by herself as soon as possible certain suitable places in Eastern Inner Mongolia as commercial ports. The places which ought to be opened are to be chosen and the regulations to be drafted by the Chinese Government, but the Japanese Minister must be consulted before reaching a decision.

4. If there are Japanese and Chinese who desire to coöperate in agricultural enterprises, including incidental manufacture, the Chinese Government shall forthwith give its permission.

Group III. The relations between Japan and the Hanyehping Company being very intimate, if the said Company comes to an agreement with the Japanese capitalists for coöperation, the Chinese 


\section{THE FALL OF TSINGTAU}

Government shall forthwith give its consent thereto. The Chinese Government further agrees that without the consent of the Japanese capitalists, China will not convert the company into a State enterprise, nor confiscate it nor cause it to borrow and use foreign capital other than Japanese.

Group IV. China to make a declaration by herself in accordance with the following principle: No part of China's coast, bays, harbors, or islands shall be ceded or leased to another Power.

Group V. Yangtze Railways - to be confirmed by exchange of notes.

A. As regards the right of financing by loan the Wu-chang-Kiu-kiang-Nan-chang Railways, the Nan-chang-Hang-chau Railway, and the Nanchang-Chao-chau Railway, if it is clearly ascertained that other Powers have no objection China shall grant the said right to Japan.

B. As regards the right of financing by loan the Wu-chang-Kiu-kang-Nan-chang Railways, the Nan-chang-Hang-chau Railway, and the Nanchang-Chao-chau Railway, the Chinese Government shall promise not to grant the said right to any foreign Power before Japan comes to an understanding with the Power which is heretofore interested therein.

\section{Fu-KIEN}

(By exchange of notes.)

The Chinese Government agrees that no Power shall be permitted to establish along the coast of Fu-kien dockyards, a coaling station for military use, or a naval base; nor will any other installations. 


\section{THE PASSING OF CHINA}

for military purposes be permitted. The Chinese Government further agrees that China will not use foreign capital to put up by herself the abovementioned establishments or installations.

The Chinese Minister of Foreign Affairs stated as follows:-

1. The Chinese Government shall, whenever in future it considers this step necessary, engage numerous Japanese advisers.

2. Whenever in future Japanese subjects desire to lease or purchase land in the interior of China for establishing schools or hospitals, the Chinese Government shall forthwith give its consent thereto.

3. When a suitable opportunity arises in the future, the Chinese Government will send military officers to Japan to negotiate with Japanese military authorities the matter of purchasing arms or that of establishing joint arsenals.

Mr. Hioki, the Japanese Ambassador, stated as follows: -

As related to the question of propagating religion (Buddhism) the same shall be taken up again for negotiation in the future.

The modified demands, while eliminating many of the drastic measures of the preceding document, still humiliated China by infringing upon her national rights and sovereignty. While Mr. Hioki had intimated to Peking in the presentation of the new document that an answer would be expected at once, China 


\section{THE FALL OF TSINGTAU}

refused to be coerced, and the first meeting adjourned in less than an hour with the question appearing very critical - at least for China.

Further discussions were held on the demands during the week, but nothing definite was decided upon until May 1, when China replied to the modified document in the form of a counter-proposal, which it declared to be its final offer. In this proposal China recognized Japanese rights of residence, of carrying on business or leasing land in the unopened districts of Manchuria, but refused absolutely to make long leases, and demanded that the Japanese should submit themselves to the Chinese police, pay the same taxes as the Chinese, likewise submitting all land disputes to the Chinese officials. At the same time the counter-proposal demanded the unconditional retrocession of Kiaochow and the participation of the Peking Government in the peace negotiations between Germany and Japan. Further, China intimated that this counter-proposal was her final word on the demands.

Japan, more than gratified with what she had already received from China as to the de204 


\section{THE PASSING OF CHINA}

mands, but eager for more, then assumed a more peaceful attitude on the matter, and wishing to avoid further complications decided to separate Group V from the original demands, but specified in her note that the demands so dropped should be left over for "future discussion." In this, Japan made it known that she expected at some future date to fulfill at every point her ambition to dominate the Celestial Kingdom.

On May 6, instructions were forwarded from Tokyo to Peking, asking the Japanese Ambassador to inform the Chinese Government that a reply to the Japanese note was desired at once.

While the above was under way, things were taking on a more serious aspect at Tokyo. Fearing that China would checkmate the ambitions of Japan, the latter decided to prepare for a coup and to win her desires, if necessary, by force. General Oka, Minister for War, at once conferred with General Akashi, Vice-Chief of the General Staff, and in a few hours Japan was mobilizing its war fleet as well as troops, in preparation for an invasion of China. The Thirteenth Division and the South Manchu205 


\section{THE FALL OF TSINGTAU}

rian Guards at Mukden and Liaoyang immediately took on war preparations for contending with the Chinese Twenty-Seventh and TwentyEighth Divisions, while in Shantung the advance guard of the Japanese troops in Kiaochow moved to Weicheng, confronting the Chinese Fifth Division. The Japanese cruisers Suwo and Sagami, which had been lying in Chinhai Bay, Korea, were given orders for full speed ahead to the Gulf of Chihli, there to pick up the Japanese Ambassador and to bring him safely back to Japan. Likewise did the first, second, and third Japanese squadrons begin coaling at Sascho and Kure.

War seemed inevitable to Japan. To China the question was different, for being in no position to contend against Japan, she realized that if war came about, it would require scarcely two days for Japan to take China.

However, as to Japan's note, President Yuan Shi-Kai found the opinion of his Presidential Board divided. The discussion was heated, and no conclusion was reached, with the result that on Friday, May 7, there was received in Peking an ultimatum from Tokyo 


\section{THE PASSING OF CHINA}

in which China was given forty-eight hours to accede to the demands or serious action would be taken.

With Japanese troops secretly moving about China on a war footing, with Japanese residents at Hankow, Mukden, and other centers, packing their belongings and preparing to move to the seacoast, Peking could do but one thing - hope for the intervention of some other Power. That help not arriving, China was forced to agree to the Japanese demands, and at half-past 1 o'clock on the morning of Sunday, May 9, China, the oldest nation in the world, passed under the virtual domination of Japan. 


\section{CHAPTER XIX}

\section{THE RESTORATION OF KIAOCHOW}

OF the siege of Tsingtau and the events that followed its surrender, but one more question remains. That is in regard to the final restoration of the once German protectorate.

Regardless of the inconsistent statements of Count Okuma on August 24, 1914, relative to eventual restoration, and that of Baron Kato on December 8, 1914, in the Diet House at Tokyo, alluded to in a previous chapter, Kiaochow and the Chinese Province of Shantung will probably become a Japanese sphere of influence after the close of Japanese peace negotiations with Germany.

In presenting her modified demands of April 26 at Peking, Japan stated that as the seizure of Kiaochow had forced her to make a heavy sacrifice, in both men and money, the latter was willing to restore the once German protectorate to China, providing the Peking Government would in turn agree that:- 


\section{RESTORATION OF KIAOCHOW}

(1) Kiaochow Bay shall be opened as a commercial port.

(2) A settlement for exclusive Japanese use shall be created in Tsingtau at a place to be indicated by Japan.

(3) If the Powers so desire, a foreign settlement shall be established in Tsingtau.

(4) The disposal of German structures and properties shall be arranged between Japan and Germany, China taking no part in the negotiations.

In the last clause enumerated above, Japan has made preparation for the final restoration of Kiaochow - in name only - to China. When the peace negotiations between Germany and Japan are brought up for discussion, Japan intends evidently to hold to her contention that the Shantung railroad is a Berlin Government concern, and not a Chinese-German private property, as the Peking Government knows it to be. China having no voice in the peace negotiations, and with Germany in no position to dispute Japan's claim, the Shantung railroad will pass into the hands of the Nipponese Government. With this concession will also go the right to station Japanese troops along the railroad right of way to pro- 


\section{THE FALL OF TSINGTAU}

tect the property, and gradually the Province of Shantung will pass from Chinese or German influence to Japanese influence. Shantung will follow exactly in the footsteps of Manchuria and under the Japanese system of freight rebates for Japanese shippers, such as has been practiced in Manchuria, Kiaochow, the birthplace of the Chinese nation, the home of the Celestial philosopher, Confucius, will have become a part of the working Empire of Japan. 


\section{CHAPTER XX}

\section{THE ENIGMA AMONG NATIONS}

Recent dispatches from Peking, disclosing the probability that President Yuan Shi-Kai will do away with the republican form of government and proclaim himself Emperor, have again brought to the front the question of the future of China. In Washington, the disappearance of the new Far Eastern Republic would be viewed with regret, for it was hoped that it would be the forerunner of other republics in Asia.

However, those who seek for the reasons for China's instability and inability to grasp in a big sense the liberal ideas of the present century, will find that upon the Powers, as agents of civilization, does much of the responsibility lie. China has been not unlike an old and heirless millionaire, who becoming unconscious suddenly awakes on his sick-bed to find himself beset on all sides by supposed relatives, who, under the guise of administering to his 


\section{THE FALL OF TSINGTAU}

wants, have made arrangements for the signing of his will and his burial. Too much attention to the division of China's wealth and too little attention to her wants, her needs, - that is the main reason for the conditions in China to-day.

It is but a-little more than fifty years since trade agents, seeking for new fields and new markets, discovered the Celestial Kingdom basking in a civilization centuries old. When the Western Nations learned of that ancient empire in the East, of its vast territory, of its mountains and their apparently inexhaustible supplies of minerals, there was a rush to the El Dorado of the Far East. The Powers first drugged China with opium, and then bit by bit they leased, stole, or reserved for themselves the best of the country.

In vain did China seek to comprehend this so-called civilization of the Occident. By 1897, when the Germans sailed into the Bay of Kiaochow and to the salute of twenty-one guns proclaimed the territory part of the Kaiser's domain, the Chinese were seething with revolt against the "foreign devils" who violated 212 


\section{THE ENIGMA AMONG NATIONS}

every right and who paid no attention to their ancestral worship or any of their customs.

The Boxer Rebellion and the siege of Peking are now an old story. It was the ancient China's last cry against extinction as a sovereign people.

With the end of that revolt, China awakened, opened her eyes, but still reposed on the couch of the immemorial civilization of her forefathers. It was apparent that one more shaking of the land was needed to arouse her into action. When the Manchu dynasty was overthrown in the revolution of 1911 and the monarchical form of government had been replaced by that of a republic, the European Powers chafed in their greediness and deceit, fearful lest China, with its four hundred and fifty millions of people, might get the new government into working order, before they could strip her of her riches.

The European Powers have been busy keeping wars and revolutions in motion on Chinese soil, hoping that China could not find herself. The turmoil in China since the breaking-out of the European war, and the recent twenty-one 


\section{THE FALL OF TSINGTAU}

demands of Japan upon Peking, are but samples of how "friendly" Powers take advantage of the weakness of the New China. Is it to be wondered at, then, that the land of the pagoda, in an attempt to regain the peace and prosperity of its former days, and to do away with the harassing of the Powers, should again turn to an Emperor and an imperial form of government?

One fact, however, stands clearly out in the situation of China to-day. It has reversed the experience of history. Other great nations, once they have reached the apex of their civilization, have deteriorated and at length have been all but swallowed up in the uprush of other nations. Persia, Athens, Rome, Spain, and Holland are examples of this.

Centuries ago the civilization of China apparently reached its apex, but the nation, instead of deteriorating, remained at a standstill, and there it has lived and continues to live. To-day we see the New China, attempting to walk, wearing the mantle of a more youthful civilization. To be sure, its step is wobbly, but gains strength day by day. Its finances are in 


\section{THE ENIGMA AMONG NATIONS}

better shape than they have ever been in the past fifty years. Patriotism, or national consciousness, something which China has lacked for centuries, is awakening, and to-day we see the people united in boycotting a neighboring nation that has heaped insult and humiliation upon them.

China is the enigma of history. 
Che laiverwide pregt

CAMBRIDGE - MASSACHUSETTS

$\mathbf{U} \cdot \mathbf{S} \cdot \mathbf{A}$ 


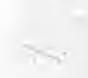


.

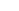


